
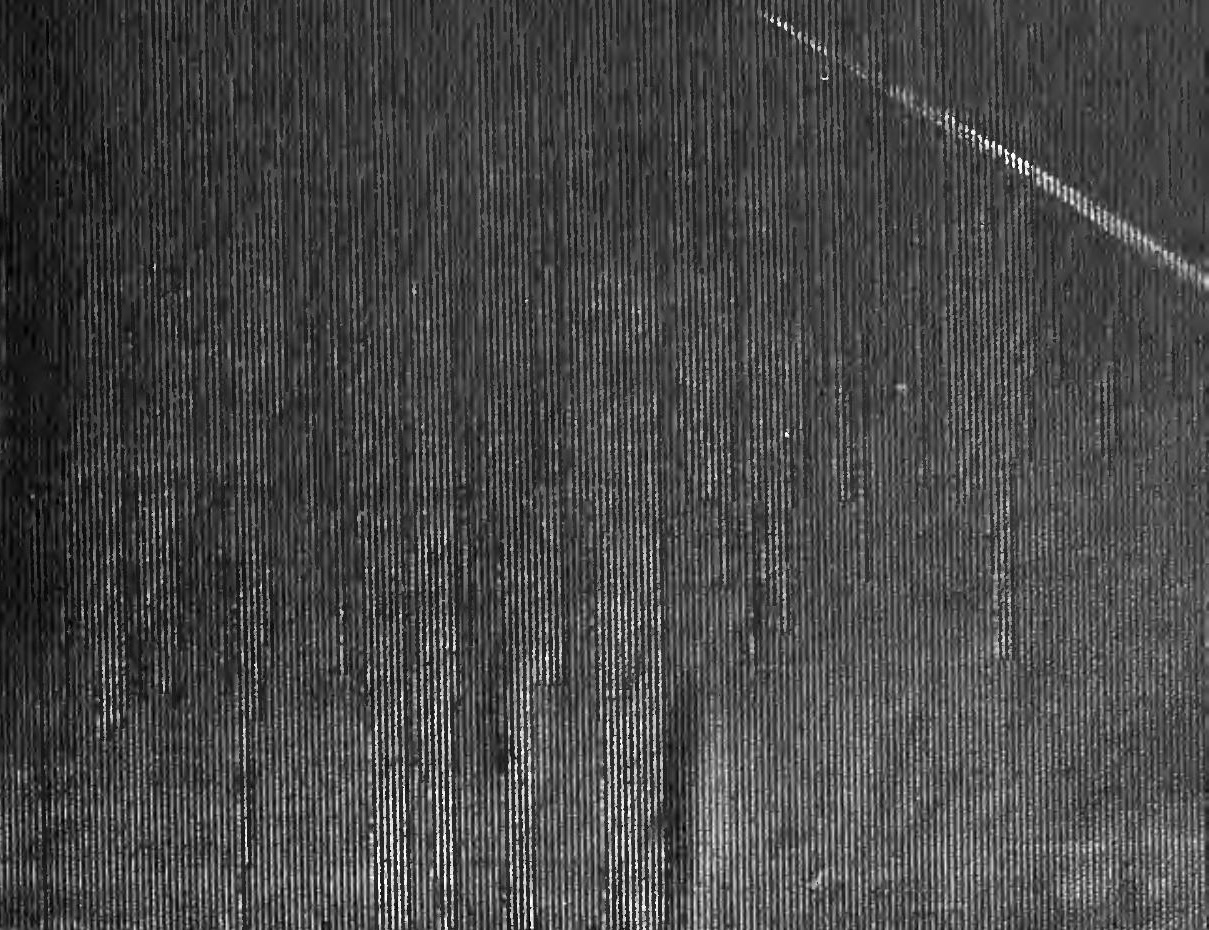
Digitized by the Internet Archive in 2008 with funding from Microsoft Corporation 


\title{
THE EVOLUTION
}

OF THE CONSTITUTION OF THE UNITED STATES OF AMERICA

\author{
AND
}

HISTORY OF THE MONROE DOCTRINE 
$-$ 


\section{THE EVOLUTION OF THE CONSTITUTION OF THE UNITED STATES OF AMERICA AND \\ HISTORY OF THE MONROE DOCTRINE \\ BY \\ JOHN A. KASSON, LL.D.}

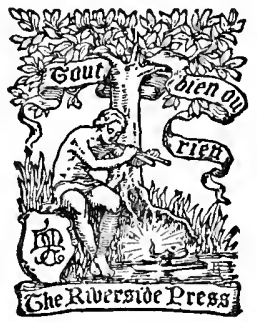

BOSTON AND NEW YORK HOUGHTON MIFFLIN COMPANY Che liuerpione Pregl Cambrioge 


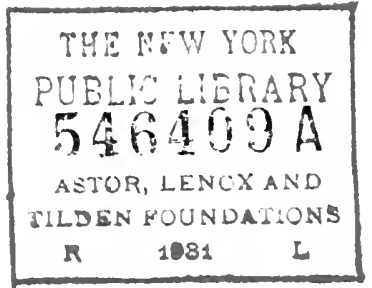

Aublished November roas 


\section{PREFACE}

ThE following story of the Evolution of the Constitution of the United States of AmerICA was originally written by request of the Constitutional Centennial Commission, under whose auspices the first centennial of its formation was celebrated at Philadelphia in 1887 , in presence of representatives of the States and of the Nation. The first edition was published as a part of the two memorial volumes, in large octavo and fully illustrated, in a form and at a cost which precluded popular circulation. That edition was soon exhausted, and only occasionally can a copy be now obtained at any price. Some desire has been expressed by its readers for a new edition adapted to more general circulation among the people, and especially for the use of students of constitutional law.

It is to meet this requirement that the present edition has been prepared, after revision and some slight additions to the text. But there has been no departure from the original plan. This embraced a clear but condensed recital 
of the conditions preliminary to the "Confederacy;" a statement of the infirmities and ineffectiveness of the Articles of Confederation, upon which the founders sought in vain to build a practical government; its entire failure as a national bond, and the recognition of that failure by the patriots of the Revolution; the successive steps by which they sought the consent of the States to a general convention to provide a substitute government; and finally, the manner in which they accomplished the organization of a NATION. The leading contested clauses of the Constitution are considered separately, and the great points of the debate connected with each are given. Thus a very clear light is thrown upon the object and scope of each important section of the Constitution, and its true interpretation is greatly facilitated, and in most cases assured.

This edition is submitted to public consideration in the hope that it will be found not only interesting to the lover of history, but especially useful to the busy man in public life, in and out of Congress, who has no time for elaborate research; and to the students of public law in the universities, colleges, and law schools of the country. 
The Author also ventures to hope that a clearer and more widely diffused knowledge of the great intellectual struggle which culminated in the adoption of the Constitution will stimulate popular devotion to its principles, and a loving loyalty to this sovereign Charter of our American liberty. We recall with glowing gratitude the virtues of our great ancestors who founded the government, and of whose labors we have inherited the splendid fruits. The habit of liberty and the long usage of prosperity have always a tendency to deaden our remembrance of the greatness of the Act which inaugurated both, and which still preserves them to us. Let not the lapse of time banish the memory of our mighty fathers, to whose persistent courage, wisdom, and patience we owe our rich political inheritance. They won it in the storm of battle, and through the tedious trials of self-sacrifice. They rescued it from anarchy, bankruptcy, disorder, and discords, which more than a century ago had brought upon our loosely confederated States the pity of their friends and the disdain of their foes. The vital forces which this constitutional union created gave to our country the purer breath of a national life, and the senti- 
ment of national honor. The Union supplemented the weakness of each with the strength of all. Instead of sectional banners stained with repudiation and local greed, this constitutional Union gave to the whole country a single flag, destined to unsurpassed respect among the nations of the earth. Year after year we add new stars to its folds as peacefully as appears a new star in the heavens from which we borrowed them.

Surely a system of government which has established the essential liberties of the people under the orderly limitations of fundamental law, and which has approved itself to successive generations by an unparalleled experience of national growth, prosperity, and happiness under its provisions, will never cease to be a most interesting study alike for statesmen and students.

That part of American foreign policy known as the Monroe Doctrine has acquired so much authority, both at home and abroad, that its influence over our people and their representative statesmen has become almost equal to that of a provision of the national Constitution. I have therefore added to this volume a history of the 
origin and development of that Doctrine, mainly derived from the original records on file in the Department of State at Washington.

John A. Kasson.

WAShINGTON, October I, Ig04. 



\title{
CONTENTS
}

\author{
I \\ Pagss \\ INTRODUCTORY • . . . . . . \\ II \\ THE PRELIMINARIES OF THE CON- \\ FEDERACY . . . . . . . 6-I7 \\ New England plan (i643). \\ Penn's plan (1697). \\ Franklin's plan (1750). \\ Otis's proposition ( 1764$)$. \\ Continental Congress (I 2 Colonies) (1774). \\ Hawley's plan (I 775). \\ Paine's plan ( 1776$)$. \\ Colonial Congress $\left(\mathrm{I}_{776}\right)$.
}

DECLARATION OF INDEPENDENCE

Was national act of the whole, not an act of the several Colonies.

No one Colony separately independent. This Declaration only national bond until Articles of Confederation were accepted by the last State $(178 \mathrm{I})$.

Washington's lament.

No real central government.

Demands for a stronger government.

Congress not vested with sufficient power.

Confederation finally ratified. 


\section{III}

\section{THE ARTICLES OF CONFEDERA-} TION, I78I . . . . . . . $18-25$

Provisions of the Compact.

Causes of its weakness.

\section{IV}

PRELIMINARIES OF THE CONSTITUTIONAL CONVENTION OF 1787 . . . . . . . . 26-52

Washington's demand for more power in Congress.

Reluctance of States to grant it.

Conditions growing worse under the Confederation.

New York in favor of a new Convention of

States (July, $\mathbf{1 7 8 2}$ ).

Virginia's adverse action and its effects. Washington's circular letter to the States. Infirm and dissolving Congress ( 1784 ). 1785 a year of disaster to industry and commerce.

Disorderly financial system in States, and unjust laws.

Convention of five States at Annapolis (I786).

Deplorable condition of the people.

Annapolis recommendation of general Convention of all States to be held at Philadelphia approved by Congress.

Action thereon by the States.

General demoralization of political conduct. 


\section{V}

\section{THE CONSTITUTIONAL CONVEN-} TION . . . . . . . . . 53-72

The character of its members.

Roll of delegates present.

Their origin and character.

Sessions secret, and why.

Virginia's plan.

Individual schemes.

Schemes of New Jersey and Connecticut.

Plan of Virginia in detail.

Plan of Connecticut in detail.

Plan of New Jersey in detail.

Fundamental division in Convention for a

National or Federal Government.

The former prevails.

VI

THE DEBATE ON THE LEGISLATIVE ORGANIZATION . . . 73-9r

To consist of two Houses.

How to be chosen.

Arguments of different statesmen.

Discordant demands, apparently irreconcil-

able.

Committee of conciliation.

The old States fear future new States.

\section{VII}

THE DEBATE ON THE JUDICIAL ORGANIZATION • . . • • • 92-95

Appointment and removal of judges.

Extent of jurisdiction.

Trial of impeachments. 


\section{VIII}

ORGANIZATION OF THE EXECUTIVE POWER . . . . . . . 96-II3

Election of the Chief Executive by Legislature, or by Electors, or by Governors of States?

Should the authority be vested in a single or plural Executive?

Discordant views, also, as to removability, responsibility to Legislature, term of office, and veto power.

Question of ineligibility to a second term.

How removable for misconduct.

Result of the protracted debate.

\section{IX}

\section{OTHER SPECIAL PROVISIONS OF} THE CONSTITUTION . . . II4-I98

The questions of fundamental principle settled.

The Committee of Detail appointed.

Report of form of Constitution and detail.

Its characteristics.

Votes on different clauses.

Who should be qualified voters.

Ratio of representation.

Washington's only participation in debate.

Congress to control national elections.

Debate on national control of militia.

A Council of State proposed.

Jurisdiction over sumptuary laws.

Jurisdiction of treason.

The war power. 
Question of power over corporations and internal improvements.

The trial of impeachments.

Control of congressional elections.

Compensation of members of Congress.

Question of taxing exports.

Debate on the regulation of foreign and interstate commerce.

Taxation of commerce for protection or for revenue?

Debate on bills of credit and legal-tender money.

POWER TO MAKE TREATIES AND THEIR FORCE

Various depositories of this power proposed.

Question of requiring ratification of treaties by law.

The House of Representatives excluded from participation by vote of ten States to one.

Question of majority of senators required to ratify.

President Washington's construction of the treaty-making power, the House of Representatives excluded.

Decision of Supreme Court - Treaties may supersede prior laws, and laws may supersede prior treaties.

RIGHT TO ORIGINATE MONEY BILLS

Effort to confine revenue and appropriations to House of Representatives.

Distinction between revenue and appropriation bills.

Exclusive right of House of Representatives limited to revenue bills. 
ADMISSION OF NEW STATES

Fear of influence of new States in the West.

Limitations proposed to preserve control of old States in Congress.

Number admitted to be limited.

To impose conditions on admission.

Final conclusion.

NATIONAL CONTROL OVER STATES

Right to negative state laws.

Proposal of Virginia.

Right to use national force against States. Resolution to declare laws of the Union supreme and to use militia to enforce them.

GUARANTEE OF REPUBLICAN FORM OF GOVERNMENT TO THE STATES AND AGAINST INSURRECTION

Debate.

Conclusion.

MODE OF RATIFICATION OF THE CONSTITUTION

By the state legislatures, or by the people?

The fundamental question again.

The debate and decision.

Number of States required to ratify.

OATHS OF STATE OFFICERS TO SUPPORT THE CONSTITUTION

The debate and the motive.

SIGNATURE AND PUBLICATION OF CONSTITUTION

Final effort to amend the final draft.

"Shall the Constitution as amended be adopted ?" 
A solemn moment.

Desire for unanimity in signature.

Franklin's appeal.

Three members present refuse to sign.

Letter accompanying its transmission to the States through the Confederate Congress.

Hostility in the Congress.

Transmission to the States.

\section{$\mathrm{X}$}

\section{THE ACTION OF THE STATES IN} RATIFICATION . . . . . . I99-206

The two questions.

Activity of enemies of Constitution.

Leaders on both sides enter contest.

Votes of the different States.

Action of Virginia and New York.

\section{$\mathrm{XI}$}

\section{SEQUEL OF AMENDMENTS . . . 207-212}

Twelve Amendments proposed by the first

Congress.

Ten of them adopted by ten States.

Eleventh Amendment (proposed by third Congress) dilatorily adopted by vote of twelve States ( 1798$)$.

Twelfth Amendment adopted (1804).

Thirteenth, Fourteenth, and Fifteenth

Amendments adopted (1865, 1866, 1870).

Varying tide of public opinion.

Conclusion. 


\section{APPENDIX}

RIGHT OF HOUSES OF CONGRESS TO REQUIRE FROM THE EXECUTIVE DOCUMENTS OR INFORMATION? . . . . 2I5-220

\section{HISTORY OF THE MONROE DOC-} TRINE . . . . . . . . . .22I-273

I. The History of the Monroe DeClaration OF 1823. . . . . 223

II. The Monroe Doctrine in Later YEARS • • • • • • • 249 


\section{THE EVOLUTION OF THE UNITED STATES CONSTITUTION}





\section{THE EVOLUTION OF THE UNITED STATES CONSTITUTION}

\section{I}

\section{INTRODUCTORY}

ThE political debates of the present generation leave a painful impression of the neglect of constitutional study. A failure to apprehend the reasons upon which constitutional provisions were founded has too frequently led astray the public judgment. In this neglect numerous theories of construction have found their source, which in turn have led to additional debate, until the public records of discussion on constitutional questions have become a massive collection, which obscures, far more than it enlightens, the popular mind. In politics, as in religion, the commentaries have superseded the authority, as they have darkened the simplicity, of the original text. It has become a duty of patriotism to awaken the spirit of constitutional inquiry, emancipated from the prejudices of party.

The existing histories of the Constitution, and the legal commentaries upon it, afford am- 
ple material for forming a correct judgment. But, unfortunately for the general public, they are too voluminous or too expensive for the attainment of a wide circulation among the people. The Constitutional Centennial Commission, therefore, thought it wise to add to their work commemorating the great anniversary a condensed history of that instrument, which even the busy American people may find time to read.

They especially appeal to the youth and to the young manhood of the country, now preparing in the schools and universities for the higher duties and functions of citizenship, to abandon the study of the superficial theories of modern party politics for the nobler study and profounder thoughts of our constitutional Fathers, - the creators of our free and powerful government and the founders of a republic which in a single century has advanced to the foremost rank of nations.

The present union of the States, for which the Fathers so long struggled against reciprocal fears and jealousies, and amidst clashing interests, will be perfected in proportion as we agree in our appreciation of the Constitution which created and preserves it.

All vigorous and harmonious national life demands some object of common reverence and devotion. In monarchical countries this 
object is the Crown, or the person on whose head it rests. In our republic no living President, accepted or rejected as he is by a varying majority and at frequent intervals, can ever become the object of general and concentrated respect and affection. It is the great Charter bequeathed to us by our Fathers, and that alone, which can give to our whole country its central object of obedience and reverence, an object which shall rise above all the changing purposes and alliances of the passing hour. It stands supreme, above us all, ruling our rulers and receiving their oath-bound allegiance. It is surrounded by many guards against the assaults of transient human passion and the aggression of man's selfish ambitions. It rises imperially above the Congress, the Courts, and the President. It was living before we came, it will live after we depart. There it stands, and is ordained to remain, immovable, unchangeable, save in accordance with the laws of its own life, grand in its simplicity, majestic in its power. To this only Sovereign of our jurisdiction and Lord Protector of our rights and liberties our allegiance and our devotion are worthily consecrated. May the youth of our time, when they shall be seated in the places of trust and authority, show themselves the enlightened and willing servants of this immortal Sovereign. 


\section{II}

THE PRELIMINARIES OF THE CONFEDERACY

ThE Act which was signed at Philadelphia on September 17,1787 , was not so much a sudden creation, an inspired fact of that memorable year, as it was a logical growth out of many years of thoughtful and painful experience.

The principles of that nationalized union which the Constitution accomplished had already been stirring in the breasts of the wise and the patriotic for three generations. As far back as 1643 , four weak colonies in New England combined in a union for their defence against all common dangers, and provided for its continuance by a common parliament. In 1697, William Penn proposed an annual "congress," consisting of two delegates from each colony. They were to have power to provide ways and means for supporting their union, maintaining their common safety, and regulating their commerce. In I754, Franklin prepared a plan for the union of the colonies, with a triennial legislature, and a governor-general to be appointed by the English government. Each colony was to retain the control of its exclusively domestic affairs. A 
PRELIMINARIES OF THE CONFEDERACY $\boldsymbol{7}$ decade later, James Otis, in the Massachusetts Assembly, pronounced for an American congress in such emphatic tones that delegates from nine of the colonies were induced to assemble in New York in 1765 , to consider their common interests and to protest against imperial taxation.

The activity of British parliamentary aggression increased. In like proportion the spirit of American union became more active; and in 1774 the delegates from the inhabitants of twelve colonies met, as a Continental Congress, for the protection of their common rights. The conception of a continental, or American, union and legislature was becoming more and more familiar to the people. In I 775, Joseph Hawley proposed an annual parliament with two Houses.

In January, I776, there appeared a pamphlet from the hand of Thomas Paine, in which he advocated with all the vigor and terseness of his unsurpassed rhetoric a more resolute advance. "Let a continental conference be held," said he, "to frame a continental charter, drawing the line of business and jurisdiction between members of Congress and members of Assembly, always remembering that our strength and happiness are continental, not provincial. ... We have every opportunity and every encouragement to form 
the noblest, purest Constitution on the face of the earth." The convention which he proposed for this end was to consist of two members for each corporate colony, chosen by its legislature, like senators in the present Congress; two more to be chosen by the Colonial Congress out of each colonial delegation; and a larger number to be chosen directly by the people, like the present House of Representatives.

Six months later the Colonial Congress, in which now all the thirteen colonies were represented, denounced the dominion of England, and declared their own complete and final independence.

In discussing the nature of our union of States, whether perpetual or dissoluble at the will of its members, the disputants have not attached sufficient significance to this great act of the $4^{\text {th }}$ of July, 1776 .

It was not a declaration of independence by each separate colony as a distinct civil corporation. It was a joint and national act, the act of " ONE PEOPLE, to dissolve the political bands which have connected them with another, and to assume, among the powers of the earth, the separate and equal station to which the laws of nature and of nature's God entitle them." The colonies, separately, did not proclaim their independence nor claim among the powers of 
the earth a separate and equal station. It was a united national act which dissolved all their provincial obligations. "We, therefore, the representatives of the United States of AmerICA, in general Congress assembled, . . . do, in the name, and by the authority of the good PEOPLE of these colonies, solemnly publish and declare "freedom, independence, and the absolution of allegiance to the British crown, with "power to levy war, conclude peace, contract alliances, establish commerce, and do all other acts and things which independent States may of right do." All these rights and powers were declared to be in the "United," not the individual, States.

This conception of their act frequently appears in the debates of the Constitutional Convention and in later debates. In the South Carolina Legislature, in I 788 , on the question of calling a convention to ratify the new Union, one of their most notable statesmen, Charles Cotesworth Pinckney, speaking of the Decla. ration of Independence, said: "This admirable manifesto sufficiently refutes the doctrine of the individual sovereignty and independence of the several States. . . The separate independence and individual sovereignty of the several States were never thought of by the enlightened band of patriots who framed this Declaration. The several States are not even 
mentioned by name in any part. . . . Let us then consider all attempts to weaken this union, by maintaining that each State is separately and individually independent, as a species of political heresy which can never benefit us, but may bring on us the most serious distresses." An argument and a prophecy in one statement.

The Declaration formed the only constitution or written bond of the independent United States until the last State ratified the Articles of Confederation, March I, I78I.

But the colonies, now States, did not proceed upon that theory of united rights to its logical result of fortifying the central authorities. Having a history of both separate and joint resistance to a common sovereign in England, they were jealous of any centralized power which was not aimed sharply and directly against the military power from which they sought deliverance. Some of them, being more liable to invasion and plunder than others, were unwilling even to allow central control of the military forces and operations. Communications with many of the colonies were limited and difficult, and personal knowledge of leaders insufficient to secure confidence. Military organization was everywhere local. Local jealousies were easily inflamed, and personal ambitions were abundant. Local appeals to protect home interests only were largely effective in 
PRELIMINARIES OF THE CONFEDERACY II

closing the eyes of the people to the greater proposition, that local interests could only be permanently protected by a common devotion to the general and united interests. They could not understand that a central power, located in Philadelphia or Annapolis, could watch equally well the coasts of Rhode Island and of Virginia, or apply equally just regulations of commerce to New York and South Carolina. The obstacles to the creation of an effective legislative and executive power over all the States were enormous, and appeared insurmountable. While their independence was national, their personal aspirations were still provincial. They could not agree upon the terms of a league or confederation. Congress had proposed Articles of Confederation, vesting very limited, but inherent, powers in Congress, in 1777. But the war was nearly over before their acceptance by all the States.

The primary cause of this delay is to be found in the fact that Congress was not elected by the people. Its members were simple delegates of the provincial authority, and revocable at will, like diplomatic agents. They had no inherent authority. The strongest and ablest men remained largely at home, preferring the dignity of the controlling authority in the State to that of a subordinate agent at Philadelphia. 
Washington made urgent appeals on this subject, especially to his friends in Virginia. He wrote to George Mason in 1779: "I cannot refrain lamenting in the most poignant terms the fatal policy, too prevalent in most of the States, of employing their ablest men at home in posts of honor or profit till the great national interest is fixed upon a solid basis. .. Where are our men of abilities? Why do they not come forth to save our country? Let this voice, my dear sir, call upon you, Jefferson, and others." He had before appealed to Harrison, Wythe, Nicholas, Pendleton, and Nelson " not to be satisfied with places in their own State while the common interests of America were mouldering and sinking into irretrievable ruin, but to attend to the momentous concerns of an empire."

Nothing shows more conclusively than these touching appeals from the great heart of Washington that the separate colonial States did not yet grasp the idea of a great continental nation. 'The union had become for them an organism designed only to establish the independence of the individual States. Their vision was checked by the boundary-line defined in their colonial charter. They saw not yet the finger of God pointing to a grand, united people, spanning the continent with a 
supreme and powerful central government, protecting popular liberty, securing personal rights, and symbolized by a starry flag with which the world should have none to compare, so radiant with hope, so illustrious in peace, and so bright with promise to mankind.

In the mean time Congress remained a mere adviser of the States. It could only recommend measures which the States had the liberty to adopt or reject, in whole or in part. Congress had become a beggar at their doors. Nothing is so difficult to persuade as the surrender of power by its possessors. The States were in fact assuming a sovereign power, and could not be induced to transfer it voluntarily to another authority. The force of adversity, even of necessity, was required to convince them that only by the surrender of a part could they possess the benefits of the whole.

The leaders of the patriotic movement soon became convinced that no combination of a central government could be accomplished through the action or the recommendation of that Amphictyonic Council, styled a Congress. Mr. Edward Rutledge, as early as August, I 776, suggested to Robert R. Livingston the appointment by the States of a new and special Congress for the purpose of organizing a confederation. There does not appear any 
encouraging echo to this proposition, from any authoritative quarter, until four years later. Meantime Congress struggled along as best it could, directing warlike and diplomatic operations through its committees, and always subject to the changing will of the several States, and to their refusal or neglect of the duties required of them for the general welfare. The difficulties of the situation became more and more apparent as the war dragged its weary course, and complaints against the army, as well as coming from the army, were heard. In 1 780 , the four New England States gave expression to their impatience over the intolerable condition of central affairs by meeting in convention at Boston, in the month of August. They demanded a substantial union, with a visible head, and a Congress "competent for the government of all those common and national affairs which do not nor can come within the jurisdiction of the particular States." They invited their own States and New York, with all others disposed to come, to meet in convention at Hartford. The following month Governor Clinton recommended the acceptance of the invitation, saying, "Our embarrassments in the prosecution of the war are chiefly to be attributed to a defect of power in those who ought to exercise a supreme jurisdiction; for while Congress only recommends, 
PRELIMINARIES OF THE CONFEDERACY 15

and the different States deliberate upon the propriety of the recommendation, we cannot expect a union of force or council." Philip Schuyler, supported by the Senate, responded in words the truth of which has been strongly reinforced at a later period of our history: "We perceive the defects of the present system, and the necessity of a SUPREME AND COERCIVE POWER in the government of these States; and are persuaded that, unless Congress are authorized to direct uncontrollably the operations of war, and enabled to enforce a compliance with their requisitions, the common force can never be properly united." Hamilton demanded more emphatically an im. mediate convention, with full authority to set up a vigorous confederation. General Greene also expressed the feeling of the army when he wrote to a Congressional delegate, "Call a convention of the States, and establish a Congress upon a constitutional footing."

The Hartford Convention assembled in November, New York only being present with the Eastern States. Their resolutions were not only patriotic, but statesmanlike. After adopting propositions to strengthen the public credit, they agreed upon a communication to be addressed to all the States. Experience had by this time clearly shown that the merely recommendatory powers of Congress were wholly 
insufficient. They must be changed to mandatory. "All government supposes the power of coercion," they said; "this power, however, never did exist in the general government of the continent, or has never been exercised.... The States, individually considered, while they endeavor to retain too much of their independence, may finally lose the whole. . . . We shall be without a solid hope of peace and freedom unless we are properly cemented among ourselves." An account of all their proceedings was transmitted to Congress, and to General Washington, as well as to all their sister States.

The patriotic earnestness of this convention appears to have at last moved the diverse minds towards greater union and a stronger central power. Their report was read in open Congress in December, and referred to a committee which embraced some of the strongest members. Pennsylvania and New Jersey gave further evidence of a desire to increase the powers of Congress.

Finally, on March I, I 78 I, amid expressions of general satisfaction, the last signature was affixed to the Articles of Confederation, in the presence of Congress. In view of their ratification, Mr. Duane, of New York, wrote: "Let us devote this day to joy and congratulation, since by the accomplishment of our 
federal union we are become a Nation. In a political view it is of more real importance than a victory over all our enemies." The final ratification was formally announced to the several States, and to diplomatic agents abroad for the information of friendly foreign governments.

As we now read these Articles, we are amazed that they should have been the subject of congratulation, as if they were the completion of the work of national organization. Yet it is only by an appreciation of the patriotic gratification then expressed over that narrow grant of national power that we can understand the extent of the reluctance of the States, particularly of the delinquent States, to surrender for the general welfare the least share of their newly-acquired independence. Time, discussion, experience, personal association, all were needed as ripening influences for the real constitution and union which were still in the bud, and still exposed to many dangers of cold and heat. On all affairs of serious import each State would fain reserve a power of veto. Local fear and jealousy lurked in every paragraph of this frail bond. A review of the powers which it refused, or closely limited, will disclose to us the unhappy condition in which it left a struggling but hopeful nation. 


\section{III}

\section{THE ARTICLES OF CONFEDERATION, I78r}

EACH State retained "every power, jurisdiction, and right not expressly delegated." By this they prohibited all development induced by the logic of events and by the necessities of inevitable growth.

The States agreed to defend each other against any attack made upon them, under whatever pretence.

The free inhabitants of one State were to have equal privileges of movement, trade, etc., in all other States, subject only to the prevailing conditions of local citizens.

Each State was to have one vote, and a number of delegates not less than two nor more than seven, all maintained at the expense of the State sending them, and prohibited from receiving any salary or emolument from the United States, even if administering an office under them. The delegates were to be annually appointed, and revocable at the will of the State. They were to meet in Congress on the first Monday of November of each year.

The sixth article prohibited each State from any alliance, treaty, or confederation with each 
other, or with a foreign State, without consent of Congress, and from laying any duties inconsistent with the treaties then in negotiation with France and Spain. Commercial regulation and imposts and duties remained within the power of each State.

The several States retained the right to issue letters of marque and commissions to vessels of war, after war should have been declared. But the power to make war and peace was vested in Congress.

Taxes for war-charges and for the common expenses were to be laid and levied by the individual States in their respective proportions, without power in Congress to enforce or interfere with their collection.

The United States could make no treaty of commerce which should restrain a State from prohibiting the exportation or importation of any goods or commodities whatever.

The States retained the power to coin money, while granting the same power to Congress; but Congress might regulate the alloy and value. The States retained power also to appoint the regimental officers in the army of the United States.

The plan of the confederation contemplated a government of national affairs by special committees of Congress. It could appoint one of its own members to preside; but so jealous 
were they of the semblance of a single executive that they limited his service to one year, and made him then ineligible for the two years following, ignoring all the benefits of personal experience in affairs, even in time of war.

Having enumerated the narrow powers which Congress might exercise, they put upon that body the following further limitation:

"The United States in Congress assembled shall never engage in a war; nor grant letters of marque and reprisal in time of peace; nor enter into any treaties or alliances; nor coin money; nor regulate the value thereof ; nor ascertain the sums and expenses necessary for the defence and welfare of the United States or any of them; nor emit bills; nor borrow money on the credit of the United States; nor appropriate money; nor agree upon the number of vessels of war to be built or purchased, or the number of land or sea forces to be raised; nor appoint a commander-in-chief of the army or navy ; unless nine States assent to the same." This required a majority of two thirds for any of these acts.

The consent of nine of the thirteen States was required to vest any power in the General Committee of Thirteen, authorized to sit in the recess of Congress; and even then no power could be delegated to this committee which was enumerated in the Articles as spe. 
cially requiring the assent of nine States for its valid exercise.

The Articles further declared that "the Union shall be perpetual;" and styled the compact, "Articles of Confederation and Perpetual Union." No amendment could be made except by agreement of Congress, with the ratification of every State. Each State bound. itself to abide by the decisions of the Congress in all matters submitted to their jurisdiction by the Articles of Confederation.

This "firm league of friendship" between the States was reported from a committee on July I 2, I 776, and was under debate from time to time for two years. At the date of July 9, I 778, only ten States had ratified it. And when Maryland completed the ratification, in March, I78I, these Articles represented the entire progress of the country towards a solid union during the five years of experience of war and weakness and inefficiency of the government. Justice demands of history some explanation of this unsatisfactory result, which shall be consistent with the undoubted patriotism and the unquestioned intellectual ability of the statesmen of that time.

The colonies were originally established under the control of different political and religious ideas, and their immigration was from variant nationalities. The New England colo- 
nies were of more uniform composition than any other group. Protestant individuality and sturdy personal independence were there most emphasized. Commerce became their controlling interest. The town-meeting, the common school, the church-meeting, and the militia formed the foundation of their social organization. The popular elements in New York were largely of Dutch origin, not given to enthusiasm, not sympathetic, but tenacious of opinion and of property interests. There were found large agricultural estates and seigniorial rights which divided the control with commercial interests. English hereditary characteristics both here and in New Jersey mingled with and modified those of continental origin. In Pennsylvania the elements of population were composite. The English religious opinions and sentiments introduced by Penn influenced a more lethargic population from continental Europe, and disposed their minds to the arts of peace and the love of concord. The moral position of the state was that of a mediator. The controlling elements in Virginia were of good English origin, exercising a positive dominion over that portion of the white population which represented an inferior immigration of questionable antecedents. Like the trained leaders of New England, the educated leaders in Virginia and in South Carolina were men of clear perceptions, 
decided opinions, and strongly attached to political theories. The Southern States were generally controlled in their material interests by the demands of agriculture. While slavery existed in small degree in the Northern States, it was a powerful interest only in the South. The dominant religious sentiment also varied in the various States. In some the church and schools were supported by state taxation, in others not. To these various and often conflicting elements must be added the pro-slavery and anti-slavery dissension already existing, and not limited by geographical divisions.

Besides these considerations, there existed that natural distrust of strangers, and especially of their influence in any degree over domestic affairs of the different colonies, which can only be obviated by frequent association and intimate acquaintance. The close association of the officers of the army during the war of independence, their participation in common perils and struggles and for a common object, had with them effected to a large extent the removal of this distrust. The movement for a closer union of the States found among them its most ardent supporters and constant advocates. Their descendants, in the Society of the Cincinnati, commemorate still the patriotic efforts of their ancestors to accomplish the great constitutional union. 
The opposition, both inert and active, to a genuine and vigorous national authority, appeared most uniformly in the local legislatures, and among men who were not personally engaged in the war. They transferred their opposition towards alien English control to alien American control; for they still regarded the other colonies, in some proportion to the distance of their territory, as aliens and strangers to their respective commonwealths. Their confederation itself, therefore, was little more than a treaty between forced allies, who were jealous of each other, and would each retain a veto upon the acts of all, except in those few points where the immediate danger from Europe controlled their fears of domestic rivalry.

Nor was human nature a century ago free from those imperfections which to-day mark the characteristics of our public life. Personal envies and jealousies and competitions were too rife for the best expedition of public affairs. Personal criticisms were violent and often reckless. In a time of war, when all the instruction of history enforces the necessity of a concentration of power in a vigorous, decisive, central authority, thirteen authoritative heads were interposed, which, in turn, were subject to thirteen other widely separated heads. No presiding officer could remain in his place more than one year in three, lest one man or one State 
should offer talents and furnish experience which might lead to an excessive influence for himself or his State. From the perusal of the records of that epoch we rise with amazement at the unshaken patience, moderation, and firmness of Washington, who persistently sought the establishment of confidence and concord, and kept himself unsullied and faithful amidst the virulence, jealousies, and passions of the time. 
PRELIMINARIES OF THE CONSTITUTIONAL CONVENTION OF $\quad{ }_{787}$

THE abler men among the patriots then in military and civil life were not deceived by any fond hopes flowing from the adoption of this instrument. 'They clearly foresaw the difficulties and embarrassments still interposed against the successful administration of government, alike in war and peace. Hardly had the announcement of the ratification of the Confederation reached the various state capitals before the letters and pamphlets of the time disclosed its defects and insufficiency. Again was heard a call for a constitutional convention. Within a few months from the approval of the Confederacy by Maryland the dissatisfaction found wide and emphatic expression. Washington, whose efforts to secure the organization of a vigorous union and government were as constant as his devotion to his weighty military duties, showed a painful consciousness that the Confederate constitution was wholly inadequate to the demands of the time. He regarded it as chiefly important in completing the formal alliance of the States. "If the 
powers granted to the head of the States," he said, "are inadequate, the defects should be considered and remedied. Danger may spring from delay. The present temper of the States is friendly to the establishment of a lasting union; the moment should be improved; if suffered to pass away it may never return; and, after gloriously and successfully contending against the usurpations of Britain, we may fall a prey to our own follies and disputes. . . . A nominal head, which at present is but another name for Congress, will no longer do. That honorable body ... must dictate, and not merely recommend. . . . Without a controlling power in Congress it will be impossible to carry on the war." Hoping that public affairs would now put on a different aspect, he added, "but not unless Congress is vested with, or will assume, greater powers than they exert at present, and will dispense them freely, upon general principles, to the ministers of State." $\mathrm{He}$ addressed himself in this sense, and with urgency, to leaders in different States.

In the mean time Congress itself had appointed a second and able committee to examine the Articles, "to prepare an exposition of the Confederation," a plan for its complete execution, and supplemental articles. This committee reported a series of subjects upon which laws should be framed for the 
execution of the Articles, but declined to make an "exposition" of the Articles for the significant reason, among others, that "the omission to enumerate any Congressional powers would become an argument against their existence, and it will be early enough to insist upon them when they shall be exercised and disputed." So early did questions of constitutional construction arise; and so promptly was the necessity for "supplemental articles" made apparent. They proposed seven distinct recommendations for increasing the powers of Congress. All this was made known to the States, but apparently without producing a movement for their adoption.

Such incomplete measures encountered a double opposition. The States were in large part unwilling to have any force applied to their delinquency, and equally unwilling to diminish their reserved powers. The friends and advocates of a strong national government, on the other hand, were indifferent to these half-measures, knowing how far they failed of affording relief to the country. Of the latter class Hamilton expressed the sentiments when he published these words: "There is hardly a man who will not acknowledge the Confederation unequal to a vigorous prosecution of the war, or to the preservation of the Union in peace. The 
Federal government, too weak at first, will continually grow weaker. ... We ought without delay to enlarge the powers of Congress. Every plan of which this is not the foundation will be illusory."

During the years $178 I-82$ the condition of the finances was constantly growing worse, paper money had become almost worthless, the army wanted pay, requisitions were disobeyed, and anxiety and distress were general. Congress organized with more or less success some departments of administration; but these found themselves seriously ineffective for want of powers and lack of revenue. France agreed to make another small loan, with assurance that nothing more must be expected from her, and accompanied by reproaches upon the unwillingness of the States to exert themselves.

At this time of general conflict of material interests, of social elements, of political aims, and of personal ambitions, Schuyler and Ham. ilton urged, and both branches of the legislature of New York adopted, resolutions (July, 1782) unanimously recommending Congress to propose " and each State to adopt the measure of assembling a general convention of the States, specially authorized to revise and amend the Confederation, reserving a right to the respective legislatures to ratify their determinations." These resolutions were 
communicated to Congress, and to the state governments.

Meantime, the proposition to so enlarge the powers of Congress that they might obtain a revenue from duties on imports had been ratified by all the States except Rhode Island. Congress was about to send a committee to obtain the assent of that State when the Virginia Legislature (December, 1782 ), on the motion of Richard Henry Lee, most unexpectedly retracted its previous assent, on the ground that it involved a surrender of the state sovereignty.

This refusal on the part of so important a Confederate member as Virginia gave a shock to the Confederacy itself. It seemed not only a refusal of this particular measure for the support of the Union, but its principle tended against all powers in Congress which should operate in any way directly upon the citizens of a State. Yet it proved a step in the march to a more perfect union. Parties in that State divided, one led by the mover of that resolution, and supported by Arthur Lee, Mercer, and Bland; the other, by Madison, with the positive support of Washington. Meanwhile, its immediate effect operated to the serious disadvantage of the country. Hostilities had practically terminated. Adjustment of new commercial relations with Great Britain re- 
mained to be effected. Congress had no power to regulate commerce or pass a navigation act. After the peace, the question whether American vessels were national or state was raised in Parliament (May, 1783 ). Lord Thurlow said: "I have read an account which stated the government in America to be totally unsettled, and that each province seemed intent on establishing a distinct, independent, sovereign State." And Parliament decided to commit all American commercial rights to the arbitrary will of the King in council. Jay wrote that no time should be lost in raising and maintaining a national spirit in America. Gouverneur Morris replied that the British restrictions would do us "more political good than commercial mischief ;" true energy in our general government would yet be supplied. Lord North discussed our situation, and predicted utter powerlessness in our Confederacy, each State having reserved to itself every power relative to imports, exports, prohibitions, and duties, and recommended that the States be separately dealt with. They did not fail to discover in this the means of further weakening a power which with perfect union might become formidable. Slowly these English views reached and affected American opinion. Lafayette also by correspondence urged the consolidation of the Union. 
Additional pressure was brought to bear upon public opinion by the discontent and urgent demands of the army for their pay, long time in arrears. Their violent and indignant spirit was subdued only by the discreet action, patriotic words, and personal intervention of Washington, who besought them not to sully their reputation by a mutinous act at the close of a glorious career. Upon their disbandment, a few months later, they organized the Society of Cincinnati, with the emphatic pledge of an "unalterable determination to promote and cherish union between the States," and separated without a penny of pay. The influence of the army was reinforced by that of the public creditors, who were wholly unprovided for; not only the creditors at home, but also in France and Holland, all of whom became clamorous for some action looking to the payment of their obligations. Hamilton expressed utter want of confidence in temporary revenue measures which depended on state action.

In April, I 783 , and after the announcement of peace, Congress took up the New York resolutions for a general constitutional convention, and referred them to a committee of nine. Washington's earnestness for a more complete union was manifested with the profound sincerity and warmth of an apostle of 
religion. $\mathrm{He}$ addressed communications of great force, both to Congress and to all the governors of States, urging the imperative necessity of prompt and united action to rescue the country from bankruptcy and disorder, and to preserve by their union the inestimable rights secured through the long struggles of the Revolutionary war. "The honor, power, and true interest of this country must be measured by a continental scale. To form a new constitution that will give consistency, stability, and dignity to the Union, and sufficient powers to the great council of the nation for general purposes, is a duty incumbent on every man who wishes well to his country. . . . If a spirit of discussion or obstinacy and perverseness should in any of the States attempt to frustrate all the happy effects that might be expected to flow from the Union, that State which puts itself in opposition to the aggregate wisdom of the continent will alone be responsible for the consequences. . . . Happiness is ours, if we seize the occasion and make it our own. .... Whatever measures have a tendency to dissolve the Union, or to violate or to lessen the sovereign authority, ought to be considered as hostile to the liberty and independence of America." These sentiments were supported by an irresistible argument, based on the then existing condition of affairs, and 
were communicated by the governors to their legislatures in every State. He formulated no plan, but avowed his desire "to see energy given to the Federal Constitution by a convention of the people."

The first effect of this circular letter to the States was that of inducing some of them to reverse their earlier action against the power of Congress to levy the import duties within the States, which had been proposed as the first measure for the restoration of public credit. Virginia, also, after a bitter struggle, passed over to the side of Washington. Its second effect was to check the tide of what Hamilton 'styled " the epidemic phrenzy" of absolute, separate sovereignty of each individual State. But Congress continued irresponsive to the efforts of its ablest men in favor of a better union; and in September its committee recommended a postponement of action on the New York resolutions.

The British order prohibiting American ships from carrying produce to British colonies did more than all previous arguments to arouse the States to the necessity of enlarging Congressional power, in order by general legislation to resent and resist such foreign assaults on American interests. In April, I 784, the new Congress agreed to a proposition that this body should be empowered, with the assent of nine 
States, and for the term of fifteen years, to exercise prohibitory powers over foreign commerce. Jefferson, knowing how much hostile foreign powers depended on the fact that each State was always protesting for its separate sovereignty and independence of central control, in his draft of instructions for our diplomatic agents abroad, spoke of "the United States as one nation upon the principles of the Federal Constitution." Rhode Island, which had before objected to the use even of the words "Federal government," alleging there was no such "government," but only a union, again interposed her voice now. At the vote taken upon this phrase of Jefferson, he was sustained by eight States against two. The fact is worthy of note as one of the signs of an advance in the conception of a national government for the future. Washington had often before, as after this time, made free use of the word "nation," as applied to the United States.

Early in I 784 , though now a private citizen, Washington addressed to the governor of Virginia an earnest appeal for a stronger bond of union. The clearness of his views appears from the following extract: "An extension of Federal powers would make us one of the most wealthy, happy, respectable, and powerful nations that ever inhabited the terrestrial globe. Without these, we shall soon be everything 
which is directly the reverse. I predict the worst consequences from a half-starved, limping government, always moving upon crutches and tottering at every step." The new Legislature of Virginia was better disposed to strengthen the Union. Even Patrick Henry showed a yielding spirit, and Jefferson's favorable influence was pronounced.

In the Congressional session of this year four States were absent, three, becoming dissatisfied, withdrew, and the powerless remainder finding themselves deserted went home in utter feebleness. The next (Fifth) Congress, which should have assembled in November, was long without a quorum. The French chargé d'affaires reported to his government that in America there was "no general government, neither Congress nor President, nor head of any one administrative department." It seemed a near approximation to anarchy in Federal affairs.

In the following winter Noah Webster published a proposed "new system of government which should act, not on the States, but directly on individuals, and vest in Congress full power to carry its laws into effect."

The year I 785 brought to view two influences bearing upon the constitutional union, and moving in opposite directions. The Congress had chosen for its President this year 
Richard Henry Lee, a bitter opponent of inherent Congressional powers; and the New York Legislature appointed its delegates so that a majority of them joined Lee in his opposition, thus changing the position of that influential State. On the other hand, the excessive flooding of American markets with English goods, the British obstructions to the shipbuilding and the carrying trades, and restrictions upon their home markets against the products of American fishery, had combined to produce ruin to our manufactures, disaster to producing interests, and the exhaustion of the metallic currency of the country. The industrial Americans were in a state bordering on despair, and found it vain to look for relief to a Congress without power to provide a remedy. When single States sought relief by protective duties, this only served as a premium to another State to concentrate in its own ports a free foreign trade, thus made yet more valuable to itself. Duties against imports from other States necessarily followed. At this juncture Congress transferred its seat to New York.

Its assemblage there was welcomed by the industrial interests of that city with an address, in which they showed their disagreement with the recent choice of delegates by their Legislature; saying, "We hope our representatives 
will coincide with the other States in augmenting your power to every exigency of the Union." The Chamber of Commerce also begged them to counteract the injurious restrictions of foreign nations. Popular movements in the same direction appeared in Philadelphia and Boston. Pennsylvania and New York both increased their duties, in unequal degree, the one on numerous foreign goods, the other on such goods as were imported in British bottoms. The Legislature of Massachusetts pledged itself to use its most earnest endeavor to put the Federal government "on a firm basis, and to perfect the Union;" and formally admitted that the Articles of Confederation were inadequate to the purposes to be effected. They ordered their resolutions to be communicated to Congress, and to the executive of each State. They also, as well as New Hampshire and Rhode Island, passed retaliatory acts against Great Britain, to continue "until a well-guarded power to regulate trade shall be intrusted to Congress." Like Pennsylvania, Massachusetts established highly protective duties.

In addition to the embarrassments of com. merce resulting from this discordant action of the States in respect to duties on imports, and from the absence of a central power to combat the injuries to trade flowing from the action 
of foreign governments, great confusion was created by the numerous and variable standards of value and the unsteady financial laws of the several States. In some the creditors were obliged to accept real and personal estate at an appraised value in satisfaction of their judgments. In others depreciated paper was legal tender in payment for purchases, on a fixed scale of depreciation. In others it must be received at its par value. Numerous staylaws were enacted. Even in Massachusetts the courts were interrupted by riotous force. Legislation on the relation between debtor and creditor was constantly changing. There was no security for one side or the other. The rate of exchange in interstate transactions was alarmingly variable. One of the States authorized the court and jury to decide questions of debt to the best of their knowledge, agreeably to equity and good conscience. In the pressure of the times some States appeared to abandon hope of a metallic currency, and took refuge in new emissions of paper money. A British agent writes to his government: "It is with pleasure that I can inform your lordship what silver and gold is to be had in this country goes in his Majesty's packet-boats to England." Georgia redeemed its paper with specie certificates at the rate of one thousand for one, while Delaware adopted the rate of 
one to seventy-five. Virginia, overwhelmed with depreciated paper, stopped its issue after I $7 S \mathrm{I}$, and undertook to redeem it in loan certificates at the rate of one thousand for one. Judgments could be satisfied by the tender of hemp, tobacco, flour, at a rate fixed by the county courts, and even taxes were paid in tobacco.

Under these conditions contracts wholly lost the protection of the laws under which they were made. The debtors were far more numerous than creditors, and practically controlled legislation by demands which rested on the emergency alone, ungoverned by principle. Good men everywhere were struggling against the general demoralization, and openly protesting against it. It led them strongly towards the plan of a new constitution for the Confederacy, which should destroy this power in the States by conferring on Congress exclusive authority to regulate the legal-tender money of the country, and to prohibit the States from impairing the obligation of contracts.

During this year ( 1785$)$ the common efforts of Maryland and Virginia to unite the waters of the Potomac and Ohio for the improvement of commerce, and the especial desire of Maryland for a canal connecting the Delaware and Chesapeake Bays, for which the coöperation of Pennsylvania and Delaware was needful, 
induced Maryland to make a further proposition. If even these two limited lines of internal communication could not proceed without a common understanding of several States, how could all the commercial relations of the future go on if liable to the conflicting legislation of independent States? The Legislature of Maryland in this connection addressed a communication to that of Virginia, proposing that commissioners from all the States should be invited to meet and regulate the restrictions on commerce for the whole. Madison quickly saw the opportunity to inaugurate the long-desired movement for a more perfect Union, and, holding himself in the background, persuaded a state sovereignty member to offer the resolution which he prepared, for the appointment of commissioners by Virginia, to meet commissioners from all the States, to examine and report on the requisite increase of the powers of Congress over trade, their action being subject to the ratification of every State. It was quietly called up at a later period, and passed (January, r 786); and Madison was placed at the head of the commission. Annapolis was proposed as the place, and September as the time, for the assembling of the commissioners. No New England State appeared, and no Southern State south of Virginia, while even Maryland was absent from her own capital. The five States 
present were represented by men from $\mathrm{New}$ York, New Jersey, Pennsylvania, Delaware, and Virginia, who believed in more far-reaching provisions than those suggested by the original resolution. Their sessions were soon closed, with a recommendation to their States to obtain a meeting of all the States at Philadelphia in the following May, to consider the situation of the country, and to devise the measures necessary to make the Constitution adequate to the exigencies of the Union.

Before the meeting at Annapolis, new efforts were made in Congress to enlarge its powers. Charles Pinckney reported from a committee seven amendments to the Articles of Confederation, giving Congress power to regulate foreign and domestic trade, and to collect duties, which, however, must be paid over to the State in which collected; to punish treason and crimes committed on the high seas; to establish an appellate court of seven judges with jurisdiction of certain Federal questions; to establish a new system of revenue, eleven States consenting; and regulating the payment of quotas by States. After long and sometimes violent discussion, these propositions were abandoned to that great file of ever-accumulating unfinished business. The country ceased to expect relief from its Congress. New Jersey was gained to the plan of a convention 
for enlarging the powers of the general government. The taxation on her imported goods, introduced through the port of New York, and the practical assessment of her own citizens for the sole benefit of the New York State Treasury, opened her eyes to the necessity of a reform in the Union.

The general situation of the country in the summer of i 786 was deplorable. From a careful official report made to the Count de Vergennes in September of that year, it appears that the condition especially of New England was sufficient to impart a sentiment of despair. The common masses of the people, driven by distress, demanded the emission of paper money for their relief. Massachusetts had seen its prodigious evils in other States and refused it. These people then took arms and dispersed the courts, demanded their abolition, and that of the State Senate, and cried out for a new emission of paper, and other wild objects from which they imagined relief would come. In New Hampshire three hundred mutineers assembled to break up a court of justice, and intimidated their legislature. Many of the people of Connecticut made efforts for the abolishment of debts and the dissolution of the courts. Hundreds of farms were there offered for sale for the payment of taxes; and specie was so scarce that they hardly brought 
one tenth of their value. A British agent reported upon the like facts, and added: "Indeed, dissatisfaction and uneasiness prevail more or less throughout this country; the greater part of the people poor, and many in desperate circumstances, do not, it seems, want any government at all, but had rather have all power and property reduced to a level." The five state delegations at Annapolis, aware of this public condition, and knowing that additional commercial authority in Congress was totally inadequate as a remedy, wisely resolved to rely only on a convention with general powers to revise the entire Constitution of the Union. Guarded as was their language, it revealed to the intelligence of the country the imperative nature of radical relief. A Virginia member of Congress wrote from New York in October to Washington: "We are all in dire apprehension that a beginning of anarchy with all its calamities has approached, and have no means to stop the dreadful work." He added the suggestion that Washington's unbounded influence, if brought to bear, might quell the seditious spirit. Washington in his reply used the words, "Influence is no government."

Moved by the steady force of her great unionists, and by the increasing disorders of the several States, Virginia took at last, in 
December, I786, a firm and loyal decision. Her Assembly, with unexpected unanimity, adopted the recommendation of the Annapolis Convention, and appointed the great names of Washington, Madison, Mason, and Randolph to represent her views in the Philadelphia Convention. Wisely remembering that state legislatures had exercised the right of agreeing to national measures and then revoking that agreement at will, that part of the Annapolis report which suggested that the act of the coming convention should be effective when "confirmed by the legislatures of every State" was modified in the Virginia resolution by requiring confirmation by the States. By this method timid legislatures could transfer the decision to the people in special convention, as in fact the unionists desired. This act of Virginia was transmitted by Governor Randolph to Congress and to the governors of all the States. New Jersey was the first of the States to accept the proposition. Pennsylvania, most constantly loyal to the Union, quickly adopted it, followed by North Carolina and Delaware. Rufus King, who had long used his great influence in Massachusetts against the increase of central power, wrote Governor Gerry that he was inclined favorably to this project, though he thought it illegal in form of inception. "Events are hurrying us to 
a crisis," he said. "Prudent and sagacious men should be ready to seize the most favorable circumstances to establish a more perfect and vigorous government." New York, still obstinate under Governor Clinton, ignored the Annapolis invitation, and desired Congress to call a general convention. When the New York delegates moved it under their instructions, without mentioning time or place, it met with entire failure. King, of Massachusetts, then saw his opportunity to reconcile his past with his present views, and perhaps to bring New York into the movement. He accordingly offered (February, I 787) a plain resolution, by which Congress advised a convention to be held at the time and place which the action of Virginia had already fixed, but without naming the act of that State. It was at once accepted by Congress, and satisfied the theorists of that school with the method of initiating the convention. States could now appoint members either to the convention called at the suggestion of the Annapolis meeting and upon the invitation of Virginia, or pursuant to the recommendation of Congress; and in either case they would find themselves in one common convention. It was doubtless a wise and useful measure, in view of the rivalries of men and of the jealousies of state precedence. 
Massachusetts, troubled with a recent insurrection, accepted in February. New York a few days later concurred, and appointed Yates and Lansing, who represented more especially the ideas of state sovereignty, and Hamilton, who was a strong unionist, to be her delegates to the convention. South Carolina and Georgia appointed their delegates in April. Connecticut sent a strong delegation in May, and Maryland soon followed. New Hampshire delayed till June. Rhode Island alone maintained her isolation to the end as a non-union State, by a legislative majority of twenty-two votes against the convention.

Pending these proceedings for a convention, and late in February, Madison wrote to Governor Randolph: "Our situation is becoming every day more and more critical. No money comes into the Federal treasury; no respect is paid to the Federal authority; and people of reflection unanimously agree that the existing Confederacy is tottering to its foundation." He added that men in the East were suspected of leaning towards monarchy; others were predicting the partition of the States into two or more confederacies. He believed that unless a radical amendment of the present system was effected the partition would take place. In April he again wrote that "unless the Union was efficiently organized on republican princi- 
ples the partition of the empire into rival and hostile confederacies will ensue."

By the foregoing tedious and often unavailing steps did the people of the United States advance towards a more perfect government. The causes of this slow approximation to a result so necessary to their security from foreign foes, and so indispensable to the establishment of equal and common privileges among the citizens of different States, are not obscure. The vast extent of their territory, the communication limited by sail on the water lines, and by poor wagon-roads and bridle-paths on land, were great hindrances to a friendly and intimate knowledge of their mutual interests. The different controlling industries in various States created apprehensions of adverse legislation by a body in which these various interests should be unequally represented. Some States were more deeply in debt than others, and in deeper poverty. These feared the power and influence of the more wealthy and prosperous States. In some of them the spirit of repudiation was rife and bold; and these desired to retain the position of aliens towards any power which might be animated by a strong sense of justice. Their ideas of a home government could not be expanded to embrace a continent, or even its Atlantic region. Slavery, increased by annual importations of human beings as 
property, had obtained a solid territorial domination in one section, and but a small and unsteady foothold in another. There was as yet no brotherhood among the States, except in small groups. The limited number of delegates to Congress, many of them frequent absentees, and who represented the legislatures, not the people, were insufficient instruments for propagating ideas of union among a widely scattered popular constituency. There were fewer numbers in the Congress than in most of the state legislatures. The latter were lords, the former servants. Congressional opinion was in perpetual chains, and had the timidity which attaches to subserviency. Too much courage of conscience involved the sacrifice of position. Constant rotation in office diminished or destroyed the growth and usefulness of experience. The enlarged views acquired from the height of central government were ever nullified by the narrower aspirations of local sovereignty. Authority, whether executive, legislative, or judicial, if intrusted to persons not appointed by the state legislature itself, and irresponsible to the State, seemed to the people an abandonment of personal rights, and a return to foreign jurisdiction. All citizens of the United States were animated by the identical love of personal liberty and of free institutions which characterized each; yet each remained blind to the truth 
that there was greater security in the combined force of all than could be found in single independence and sovereignty. For war they ad. mitted the need of union. In peace only the stress of commercial conflict between the States and with foreign countries could induce them to strengthen the bonds of a general government.

While these were the prevailing sentiments, among leaders there was abundant diversity in theories of government for the Union. Systems, plans, projects, had been discussed for many years, and so often defeated or ignored that it hardly seemed within human power to revive an old or propose a new one with any reasonable probability of its general adoption. The predisposition of each State was to reject the plan of every other State. The rivalries of persons and of communities reinforced this prejudice, and covered any new scheme with clouds of doubt. It was not, therefore, to be regretted that some men of strong intellect who might have been delegates to this convention, but who were enemies to a consolidation of the Union, preferred to remain at home, and permitted their places to be filled by friends of the national movement. It was of supreme importance that the scheme of reform to be devised should have the general sanction of the initiatory body before demanding that of the States. 
PRELIMINARIES OF THE CONVENTION 5 I

This could better be accomplished by unionists of different shades of opinion than by the doubtful coöperation of persistent separatists.

It would hardly be possible to find a more melancholy picture for the contemplation of patriots than that presented by the States of the Union at the time of their appointment of delegates to Philadelphia. The public debt was in no part paid, and no provision whatever was made for its payment. The Confederacy was without revenue of its own, and without resources. Whatever gold or silver existed in the country was sent beyond seas to pay for imported goods. None of the States fully responded to Confederate requisitions; some partially complied, and New Jersey expressly refused to comply. The navigation laws of New York, Pennsylvania, New Jersey, and Maryland treated the other States as aliens, as if they were European countries. South Carolina, Virginia, Pennsylvania, and New York were taxing the trade of other States passing through their ports, and developed angry sentiments in their nearest neighbors. Connecticut taxed imports even from Massachusetts. The treaties made by the Confederation were violated in the States with impunity. Compacts were made between States in violation of the articles of the Confederacy, even by such States as New Jersey and Pennsylvania, Virginia and Mary- 
land. The demoralization had gone so far that Virginia not only refused to apply for the sanction of its compact with Maryland by Congress, but even voted against advising Congress of its existence. The legislatures and the people showed equal disregard of public and private obligations. Respect for the Confederacy had ceased at home, and it was the object of contempt abroad. Thoughtful men doubted of the capacity of the people for self-government, and began to whisper of monarchy as a cure of public disorders.

Surrounded by doubts, but inspired by hope, and powerfully urged by the dangers and distresses of the country, the delegates to this Convention made their journey by slow stages from their respective States to the city of Philadelphia, now to become once more the centre of a nation's hopes. 


\section{V \\ THE CONSTITUTIONAL CONVENTION}

The Convention was summoned for the $14^{\text {th }}$ of May, I787. The necessary quorum of seven States did not appear until the $25^{\text {th }}$ of May, when the majority of the New Jersey delegates presented their credentials. Three days later Massachusetts and Maryland increased the number to nine. The representation of Connecticut and Georgia added two more States on the 3 oth and 3 Ist of May. That of New Hampshire did not arrive until the 23 d of July, after the majority of the New York delegates had withdrawn; so that only eleven States were voted at any one time, out of the twelve represented. Rhode Island alone refused to be represented, having rejected the proposition by a legislative majority of twenty-two votes. A number of her leading citizens, however, forwarded a letter of sympathy to the Convention.

Of the characters composing this Conven" tion, the French minister wrote to his government: "If all the delegates chosen to this Convention at Philadelphia are present, Europe will never have seen an assembly more respect- 
able for talents, for knowledge, for the disinterestedness and patriotism of those who compose it. General Washington, Dr. Franklin, and a great number of other distinguished personages, though less known in Europe, have been called thither."

It was certainly most fortunate for the country, for the prestige of the Convention, and for the solidity of its work, that Virginia set the example of intrusting her commission to her greatest names. Where Washington led the way, followed by Madison, Governor Randolph, George Mason, and Chancellor Wythe, no other State would be willing to refuse a contribution of its most reputable, noblest characters. Pennsylvania responded with Franklin's vast experience and wisdom gathered on two continents, with Robert Morris and Gouverneur Morris, and was further strengthened by the great ability of Wilson. South Carolina sent John Rutledge, with the two Pinckneys. New Jersey offered her chancellor, Livingston, with Chief Justice Brearley, William Paterson, and Dayton. New York reluctantly commissioned her chief unionist, Alexander Hamilton, a born statesman, who combined indomitable force of character with a genius for the organization of States. Delaware gave her patriotic Read and her venerable Dickinson as aids in the great work. Connecticut, so rich in contributions of 
soldiers to the Revolutionary struggle, ranked herself in the forefront of the Convention when Sherman and Ellsworth and Johnson appeared there. The voice of Massachusetts found eloquent expression in Rufus King, and her opinions gathered strength from the high reputation of Governor Gerry and the wisdom of Gorham. If ever a government could be formed fresh from the brain of man, instinct with a vigorous life, and admirable in form as that fabled goddess who sprang full-armed from the brow of Jove, it might surely be expected from the midst of this assembly of the wisest and purest and most patriotic characters to which the old European or the young American continent had ever given birth. If the effort should fail now and here, the boldest of our national patriots were prepared to await in silence and unhappy resignation the alternative fates of anarchy or despotism.

The completed roll of delegates who were actually present in the Convention at some time during its deliberations shows the following names:

From New Hampshire (2) - John Langdon, Nicholas Gilman.

From Massachusetts (4) - Elbridge Gerry, Nathaniel Gorham, Rufus King, Caleb Strong. From Connecticut (3)-William Sam- 
56 EVOLUTION OF THE CONSTITUTION

uel Johnson, Roger Sherman, Oliver Ellsworth.

From New York (3) - Robert Yates, Alexander Hamilton, John Lansing.

From New Fersey (5) - William Livingston, David Brearley, William Churchill Houston, William Paterson, Jonathan Dayton.

From Pennsylvania (8) - Benjamin Franklin, Thomas Mifflin, Robert Morris, George Clymer, Thomas Fitzsimons, Jared Ingersoll, James Wilson, Gouverneur Morris.

From Delaware (5) - George Read, Gunning Bedford, Jr., John Dickinson, Richard Bassett, Jacob Broom.

From Maryland (5) - James McHenry, Daniel of St. Thomas Jenifer, Daniel Carroll, John Francis Mercer, Luther Martin.

From Virginia (7) - George Washington, Edmund Randolph, John Blair, James Madison, Jr., George Mason, George Wythe, James McClurg.

From North Carolina (5)-Alexander Martin, William Richardson Davie, William Blount, Richard Dobbs Spaight, Hugh Williamson.

From South Carolina (4) - John Rutledge, Charles Cotesworth Pinckney, Charles Pinckney, Pierce Butler.

From Georgia (4) - William Few, Abraham Baldwin, Willi:m Pierce, William Houstoun. 
Of these, eight members had signed the Declaration of Independence. The whole number of appointments made was sixty-five, of whom only fifty-five attended the Convention; and of them only thirty-nine affixed their names to the Constitution at the end of their deliberations, three expressly refusing, and others absent.

Hamilton was born in Nevis, one of the Leeward Islands; Wilson in Scotland; Robert Morris and Davie in England. Paterson, Fitzsimons, McHenry, and Butler were of Irish birth. The other delegates were native Americans. Some of them had been educated in England, but most of them in the country of their birth, which they had rescued from foreign domination, to which they had given the principles of liberty, and which they now desired to endow with the rights of a republic and with the organization of a united, free, and stable government.

The Convention at the outset provided for secret sessions. The conflict of opinion throughout the country was so great that they feared to exasperate existing divisions, and to provoke hostilities while their plan was in construction, if each day's immature proceedings and discussions were given to the public. They also believed that a more sincere and frank expression of personal opinions could be ob- 
tained from the delegates, and compromises of jarring judgments could be better secured, if they were exempt from the exterior influence of bitter prejudices. They decided, therefore, that no communication of their resolutions should be made until the whole completed work could be laid before the country, and that no individual votes should be recorded, this record being made by States.

The dilatory arrival of the majority of the delegations gave opportunity for private and personal comparison of views between the few delegates who were earliest in Philadelphia. The members from Virginia met in frequent consultation, and brought themselves into harmonious relations upon a rough draft of constitutional principles which Madison had prepared. This document, modified by their consultations, was afterwards authoritatively presented to the Convention as the plan of Virginia. The moral force of the then leading State of the Confederacy was thus, from the beginning, thrown into the wavering balance in favor of a wholly new Constitution, and against any partial amendment of the existing Articles of Confederation. Her very able delegation succeeded, though afterwards much divided upon details, in keeping the action of the Convention upon the original basis proposed by them. The discussion upon their 
resolutions began in committee of the whole house, Mr. Gorham, of Massachusetts, in the chair, on the 3oth of May; and they were finally reported, as amended, on the I 9 th day of June, and were before the Convention, as from time to time modified, until the germ was developed and ripened into the American Constitution on September 17, 1787 .

There were some individual schemes of greater or less scope offered by Charles Pinckney and by Hamilton, but they never diverted the general course and lines of debate. That of Charles Pinckney is the most notable, by reason of the form in which it has been published, and which bears so striking a resemblance to the Constitution as adopted. But his original plan submitted was not preserved, and that now attributed to him lacks authenticity. It bears internal evidence of later composition, and is in conflict, in some of its provisions, with his recorded speeches and letters. On the high authority of $\mathrm{Mr}$. Madison and of the historian Bancroft it must be rejected. Neither the scheme of Mr. Pinckney nor that of Mr. Hamilton is important in this recital, because neither of them ever became the base of the Convention's delibera. tions; and the opinions of both these distinguished delegates appear in the course of the debates upon the three plans offered in the 
name of the respective States of Virginia, Connecticut, and New Jersey.

New Jersey, pressed between her two large and powerful neighbors to whom she was liable to pay commercial tribute, desired to amend the Confederate articles, chiefly that duties might be made to bear equally on all the States, preserving her state sovereignty and equality in voting power. These points granted, she would concede further amendments.

Connecticut, also, desired to adhere to the Confederate system. With a delegation unsurpassed in experience, learning, and ability, she appears to have suggested, about the time the Virginia plan was reported, a scheme of amendment of the Confederation, consisting of several sections, the product of her experience under the infirm government then existing.

Parts of both the Virginia and Connecticut propositions were accepted and parts refused, as will appear by the following analysis of their principal clauses and the ultimate disposition made of them.

In the scheme of Virginia, which fortunately had precedence in time and in the outlined completeness of its form, were found the principles of a new and thoroughly constitutional government for the whole people, combined 
for general purposes into one nation. This qualification of "national" occurred in it nineteen times as it went into committee and twenty-five times as it was reported from the committee, and left no doubt that it was intended to substitute a new government for the whole country, to which the States should be auxiliary for only their internal economy respectively. Every attribute of sovereignty looking to their relations beyond their own respective geographical boundaries was transferred to the general or "national" government. The latter was to be independent of the individual States and in no way responsible to them. Its reliance was directly on the people, from whom it was to choose its own legislative, executive, and judicial agents, who should be responsible to itself alone.

OF THE LEGISLATIVE DEPARTMENT.

Suffrage in the "national legislature" ought to be proportioned to quotas of contribution or the number of free inhabitants (refused). It should consist of two branches, the members of the first to be elected by the people of the several States and to receive a compensation, and not to hold any other office under the United States at the same time (accepted); to be ineligible to immediate reëlection, and to be subject to recall (refused). Members of the 
second House to be chosen by the members of the first House from among persons to be nominated by the state legislatures respectively (refused), and to be ineligible to immediate reelection(refused). The " national legislature," in addition to the legislative rights already vested in the Confederate Congress, ought " to have the right to legislate in all cases to which the separate States are incompetent, or in which the harmony of the United States might be interrupted by the exercise of individual legislation" (limited to the scope of granted powers, and so adopted); the right to negative all laws passed by the several States contravening the articles of union (refused); the right to call forth the force of the Union against any member of the Union failing in its duty under those articles (refused); each House to have the right of originating all acts ("bills for raising revenue" limited to the first branch, and so adopted).

\section{EXECUTIVE DEPARTMENT.}

The national executive ought to enjoy the executive rights already vested in the Confederate Congress, and have a general authority to execute the national laws (accepted, saving confirmation of certain acts by the Senate). This executive to be chosen by the national legislature (refused); and to be ineligible for a 
second term (refused); and, together with a portion of the national judiciary, to form a council of revision (refused), "with authority to examine every act of the national legislature before it shall operate" (accepted in the veto power, with reserved legislative right of two thirds).

JUDICIAL DEPARTMENT.

"A national judiciary ought to be established," consisting of one supreme court and inferior tribunals (adopted); to be chosen by the national legislature (refused); to hold their office during good behavior (adopted); with jurisdiction over felonies on the high seas, and captures, between foreigners and citizens, between citizens of different States, over questions of the collection of the national revenue (adopted); over impeachment of national officers (refused); and questions which may involve national peace and harmony (refused in those terms).

\section{MISCELLANEOUS POWERS.}

Provision ought to be made for admitting new States out of Union territory (accepted); republican government ought to be guaranteed to each State (accepted), and also its territory (refused). All engagements of the existing Congress to be observed (accepted). Provisions 
to be made for amendment of these articles, to which the assent of the national legislature ought not to be required (accepted). The legislative, executive, and judicial powers of the several States to be bound by oath to support the articles (accepted). The acceptance of these new articles by the States to be decided by vote of conventions expressly called therefor (accepted).

The scheme offered by the State of Connecticut differed from the preceding in important particulars. Like the other, it gave to Congress jurisdiction over foreign and interstate commerce, with a revenue from the customs and the post-office (enlarged and accepted); and power to make laws in all cases which concerned their common interests, but not to touch the state authorities in affairs concerning only the local welfare (accepted in principle). But the laws of the United States covering the common interests of the States were to be enforced by the judicial and other authorities of the States themselves (refused). For certain specific purposes the United States were to establish a supreme and other necessary tribunals (enlarged and accepted). No State could make a currency of bills of credit (accepted), nor make laws violating contracts where foreigners or citizens of other States were interested (accepted with enlargement). 
The Union treasury was to be supplied by the States in the proportion which their respective numbers of free inhabitants - excluding untaxed Indians, and adding three fifths of all other persons - bore to the whole (refused). Some provision might be made for calling on the people by the United States for the enforcement of their laws; and in case of the failure of any State to pay in its quota the United States could levy and collect the same directly from the people of the delinquent State (abandoned). Criminal trials must be by jury, and in the State where the offence was committed (accepted).

The New Jersey system was intended to unite all the opponents of a new and national government, and was purely federal. It contained some important and useful amendments of the existing Confederation. It retained, however, the Congress of a single body, and provided for the election by it of a plural executive, which was little better than a committee of Congress, because the latter could at any time revoke its powers on demand of the States. The only direct revenue it granted to the United States was to be derived from duties, stamps, and the post-office. For the rest it maintained the old system of requisitions, and gave primary jurisdiction of most federal questions to the courts of the State, 
with appeal to the Federal Supreme Court. Many of its provisions were concurrent with those already approved in committee. But being based on the Confederation, the decision upon it was adverse, - seven States to three, with Maryland divided.

The most strongly marked line of division in the Convention was upon the question whether the new government should be federal or national; that is, whether it should rest upon the States as independent political powers, or upon the people of all the States as the ultimate source of all political authority. If the former idea prevailed, the new government would still be a mere league, and might be dissolved by its members, like any other league between States. If the national ideas were dominant, then the new government would hold its powers direct from the people of the entire country which should adhere to the new Constitution. In this case each separate State, while exercising its retained domestic authority undisturbed, would be merged in the nation in respect to all matters within the national jurisdiction. As to these its sovereignty and its independence would be lost. The power of a State in these relations became only the power of an individual, - that of being counted. No power of reserved and final judgment could then be claimed for a 
State without at the same time destroying the national government; that is to say, such a judgment could only be made effective by rebellion and force outside of the Constitution. It was also distinctly designed that the people - not the States as legislative corporations should establish the validity of the Constitution. Hence it was insisted, and finally resolved in the new Constitution, that the people should adopt it by special conventions called for the purpose of considering it. Thus they resorted to a power behind the state legislatures, behind even their constitutions, for the sanction of the new instrument, and as the original source of the new national rights. For this purpose the States were employed only as necessary geographical circumscriptions for obtaining the vote which bound the state corporation to the Union, as counties and towns are employed for the returns of the popular suffrages in state elections and on questions of annexation of territory. That popular affirmation then becomes a finality.

This is the logical thread which will safely conduct us through the mazes of our constitutional history, and through the long debates of its formative period, and even of the later period of the construction given to that instrument by the great tribunal which it established. In the beginning it was the "United 
States of America" who appealed "to the Supreme Judge of the world for the rectitude of their intentions," and "in the name and by the authority of the good people of these colonies" declared freedom and independence. It was only the "United States" which then claimed the right to levy war, conclude peace, contract alliances, and do all other acts belonging of right to independent States. Nowhere are these acts and powers said to belong to each of them. But this declaration established no rights; it only expressed theories and aspirations. Conflict in financial and military interests between the States very soon threw them back upon their individuality acquired under colonial charters. Their melancholy experience of disunited action during the war next inclined them to the formation of some sort of new common bond and common authority. Then they adopted the "Articles of Confederation and Perpetual Union," which they styled "a firm league of friendship with each other," and in which "each State " now appears, retaining "its sovereignty, freedom, and independence," and only delegating certain functions of state to the "United States in Congress assembled." Further to express its character as a league, a compact, and not a nation, each State expressly reserved its right to an equal vote, and to recall its delegates at any time and 
send others at will, only limiting the number of delegates to seven as the maximum and two as the minimum from each State. They had no revenue except what each State should give. Nor could the assembly so constituted act by a majority of members, or even of States. In all the more important matters the consent of nine States was required. Any alteration in the articles required the approval of every individual State. Thus state rights were not only observed, but strongly established by this first compact or treaty. This was a government resting upon and deriving its powers solely from the States as corporate bodies.

We have already traversed the time, strewn with disasters and marked by disorders increasing as time elapsed, during which the American States and people became wholly alienated from this empty form of government, which had indeed brought on them bitter reproaches at home and disdain abroad. We are prepared to witness the reappearance of the national conception of government, returning in floodtide to the minds of the patriotic builders of government. The leap from the confederate league to the constitutional union, long as it was, becomes only the dictate of experience. The corporate States no more appear as fountains of national authority, revocable at will. This act, like that of the Declaration of In- 
dependence, is in the name of the people. "We, the people of the United States, . . . ordain and establish this Constitution for the United States of America." We observe that the Confederation was "between the States,""the said States hereby severally enter into a firm league." The greater sovereignty of the people was ignored. Now, however, this ultimate popular sovereignty is in the forefront, and, by "ordaining the Constitution for the United States," imposes its will on the separate States as represented by legislatures, and overrides state constitutions and state laws. It thus asserts its overruling authority in the opening clause of the Constitution; it requires all state officers to take oath to support it; and confirms it by the people's ratification as required by its final clause. The alpha and the omega recognize only the people, and not the corporate States, as ordainers of the new Constitution. The words "league" and "compact" disappear, and the principles they represent are annihilated by the people's sovereign will.

The motives for this radical and mighty change in the form of government can be traced in the record of past events. It becomes very apparent as we pursue the course of the debates in the Convention, where its importance was so fully recognized, that the decisions of that body on the issues between 
the partisans of the national and of the confederate plans caused the withdrawal of some state sovereignty members and the abstention of some hesitating unionists.

Governor Randolph, in his opening speech recommending the national plan of Virginia, said, "We ought to be one nation." A resolution prepared by Gouverneur Morris was early accepted by six States against one, "that a national government ought to be established consisting of a supreme legislative, executive, and judiciary." And it was avowed that this supremacy meant that in collisions of authority between Union and State the former must prevail. Morris enforced his proposition, saying, "In all communities there must be one supreme power, and one only. A confederacy is a mere compact, resting on the good faith of the parties. A national, supreme government must have a complete and compulsive operation." Mason, of Virginia, struck the vital chord of our system when he said, "In the nature of things punishment cannot be executed on the States collectively; therefore such a government is necessary as can operate directly on individuals." Lansing, of New York, who afterwards seceded, moved to give States an equality of power even in the first branch of the national legislature, and said thereupon, "The sense of the Convention on this point will determine 
the question of a federal or national government." His motion was defeated, obtaining but four votes out of eleven, establishing it as the people's government in distinction from that of the States. 


\section{VI}

THE DEBATE ON THE LEGISLATIVE ORGANIZATION

THERE was a general conviction that the legislature for the Union should be composed of two branches. Pennsylvania appeared to have doubts, and her delegation alone interrupted at the time the unanimity of voices on this vote; but later they also gave their adhesion.

When the next question came, how these two branches should be chosen, the debate became interesting and much more obstinate. Were the States to retain their equality of suffrage as in the Confederacy? Should all the States have votes proportioned to their population? Should this proportion prevail in both branches of the new legislature? Should the members of both Houses be appointed by the legislatures of States or by the people? Great diversity of opinion appeared on all these points, and particularly between the representatives of large and of small States.

Hamilton demanded that suffrage in the national legislature should be proportioned to the number of free inhabitants. Madison, in. clined to feel his way more cautiously, offered 
a resolution which simply declared against equality of suffrage as provided by the Articles of Confederation, and for an equitable ratio of representation instead. He argued that, while "equality of suffrage may be reasonable in a federal union of sovereign States, it can find no place in a national government." This question was vital to the delegation from Delaware, who came specifically instructed to insist on the equality of state suffrage. The larger States felt sharply the injustice which existed for them in any government where a small population, small revenues, and small industrial interests should exert an equal influence over legislation with those of vastly greater extent. The small States, on the other hand, feared to be reduced to a nullity, with all their separate interests, if they did not obtain for the future the same equality which had existed in the past. The debate then took a wider range, and brought into collision the nationalists and the federalists on the question whether the members of the proposed Congress of two branches should be elected by the people, or appointed by the legislatures of the respective States.

The advocates of state sovereignty demanded that the state government should furnish the agents necessary to the execution of the affairs of the new Union. They still 
clung to the theory of a general government whose powers were delegated by the several States, and not derived from the people themselves, who were higher authority than the States. The equally logical nationalists, clinging to their purpose of a government with inherent powers, to be conferred by a charter deriving its validity directly from the people, and not through the state governments, demanded the election of one or both branches by the people. Some extraordinary views were presented by members while advocating their respective theories. "The people should have as little to do as may be about the government: they lack information and are constantly liable to be misled; the election ought to be by the state legislatures," said a voice from Connecticut. Charles Pinckney and John Rutledge also demanded the elective power for the legislatures of the States, the former regarding the people as incompetent to choose wisely. Said Gerry, of Massachusetts, "The people do not lack virtue, but they are the dupes of pretended patriots."

On the other hand, Wilson, of Pennsylvania, keen in perception, strong in expression, and able in debate, replied, "Without the confidence of the people no government, least of all a republican government, can long subsist. Besides, the weight of the state legislatures 
ought not to be increased by making them the electors of the national legislature. Vigorous authority should flow immediately from the source of all authority, - the people. Representation ought to be the exact transcript of the whole society." Mason thought the "larger branch should be the grand depository of the democratic principle of the government. Under the existing confederacy Congress represents the States, not the people of the States ; their acts operate on the States, not on individuals. In the new plan of government the people will be represented; they ought, therefore, to choose the representatives." Roger Sherman thought the question involved the very existence of state governments. "If it is in view," said he, "to abolish the state governments, the elections ought to be by the people. If they are to be continued, the elections to the national government should be made by them." Alexander Hamilton, opposing his colleague, Lansing, affirmed emphatically, "It is essential to the democratic rights of the community that the first branch be directly elected by the people." Mason added, "It is the only security for the rights of the people." Rutledge claimed that elections by the legislature would be " a refining process." Wilson answered South Carolina with the declaration, "The election of the first branch by the people is not the 
corner-stone only, but the foundation of the fabric." And this was emphatically true, because the new plan was built upon the sovereignty of the people, not on the States.

Most of the large States were earnest in repudiating an equal and in demanding a proportional representation in both Houses, and some of the delegates insisted that both should be elected by the people. The patriotic Dickinson, mindful of his instructions from Delaware, and recognizing as well the necessity of some compromise of opinion between the opposing elements, proposed that one branch should be elected by the people, the other by the legislature, in which Pierce, of Georgia, concurred. It was a sagacious movement towards reconciliation of the States, and was also a step towards the establishment of equal state representation in the second branch of Congress. But Madison strenuously resisted it to the last. He said, "To depart from proportional representation in the Senate is inadmissible, being evidently unjust. The use of the Senate is to consist in its proceeding with more coolness, system, and wisdom than the popular branch. Enlarge their number, and you communicate to them the vices they were meant to correct."

Dickinson still insisted that "the preservation of the States in a certain degree of agency 
was indispensable. The proposed national system is like the solar system, in which the States are the planets, and they ought to be left to move more freely in their proper orbits."

Wilson, who declared himself for the election of the second branch also by the people in large districts, rejoined, with far-seeing vision, "The States are in no danger of being devoured by the national government: I wish to keep them from devouring the national government. Their existence is made essential by the great extent of our country."

The weight of Gerry and of Sherman was thrown on the side of elections to the second branch by the legislature. Charles Pinckney threw into the debate the fruitless suggestion that the States might be periodically divided into three classes, according to their population, and one, two, or three senators allowed to them, according to their relative importance. The coming result of the long debate was indicated by the forcible remarks of Mason, of Virginia, that "the state legislatures ought to have some means of defending themselves against encroachments of the national government. What better means can we provide than to make them a constituent part of the national establishment?" The opposition, in order to bring in the smaller States, at last yielded this point of senatorial election by leg. 
islatures as preliminary to equality of state representation in the second branch; and the choice of senators, whatever their number, was by general consent conceded to the state legislatures, and the choice of the first branch was given to the people.

There still remained the vital question between large and small States, What should be the ratio of their representation in each of the two Houses? The struggle over this point was so severe and threatening that the venerable Franklin intervened to moderate its ardor, and begged the disputants to remember that their duty was to consult rather than contend. New Jersey delegates were firmly hostile to any plan which should destroy the equality of the States. The great States, with the exception of New York, were equally determined to maintain their right to a representation proportioned to their numerical superiority. The test was first taken on the first House, representing the people in distinction from the States. The Convention, remembering a former conciliatory proposition to supply the common treasury in the proportion of the number of free inhabitants with the addition of three fifths of other persons, excluding untaxed Indians, turned to this rule of direct taxation for the ratio of their representation in the national House of Representatives. It 
was only adopted by a majority vote. Massachusetts, Pennsylvania, Virginia, the two Carolinas, and Georgia, in this supported by Connecticut, gave the proposition seven votes, with Maryland divided. New York, overruling Hamilton, placed herself in opposition by the side of New Jersey and Delaware, New Hampshire and Rhode Island being absent.

Connecticut, having given that very important vote which made up the majority of all the thirteen States for the preceding proposition, naturally considered herself entitled to a potential voice in settling the question of the second House. Roger Sherman said emphatically that each State should have one vote in the Senate. "Everything depends on this: the smaller States will never agree to the plan on any other principle than an equality of suffrage in this branch." But for the time this principle was defeated by a vote of six to five, and the rule of proportional suffrage already applied to the other House was adopted for the Senate by the same vote of six to five, Maryland and Connecticut joining the other three minority States. Only one senator was assured to the small States against several to their more populous competitors. Not long afterwards the necessity for further concessions from the Virginia project became apparent, and Franklin, with Davie of 
North Carolina, encouraged the demand of the smaller States for equality of representation in the Senate. This equality of the States in that branch seemed to them the only means of saving the Constitution from threatened defeat at its inception.

Before this result was reached the debates indicate an agony of experience in the Convention, tending to breed despair in the hearts of the most faithful patriots. The Virginia plan, modified and improved, had been successfully reported, instead of the New Jersey plan, from the Committee of the Whole on June Igth. The "national" idea having been clearly established by the majority, Ellsworth, of Connecticut, who had himself accepted it, saw the propriety of removing from the text a word which gave needless alarm to $\mathrm{New}$ Jersey and Delaware; and he moved the substitution of the description, "the government of the United States," instead of "the national government," in accordance with the suggestion of Dickinson. As the substance remained, the majority at once concurred in that proposition, and without dissent. But Lansing and Yates, of New York, who had rarely made any contribution towards the harmony of the Convention, and who formed the majority of their state delegation, were resolved against yielding to any concession. Lansing, ignoring 
the progress already made, moved a return to the federal plan, and supported it by an inharmonious and discouraging speech, assailing the powers of the Convention. Mason responded with indignation against the reopening of a question which should now be considered as definitely settled by the Convention. The motion was of course defeated, and the discussion proceeded upon the manner in which the two Houses should be constituted.

Wilson made an effort to lift the eyes of his associates from the narrow ground of local and transient interests. In view of the vast extent of the territory, the immense population destined to occupy it, and the future influence of its government over the whole globe, he said, "I am lost in the magnitude of the object. We are laying the foundation of a building in which millions are interested, and which is to last for ages. . . A citizen of America is a citizen of the general government, and a citizen of the particular State in which he may reside. The general government is meant for them in the first capacity; the state government in the second. . . . The general government is not an assemblage of states, but of individuals, for certain political purposes; it is not meant for the States, but for the individuals composing them. The individ. uals, therefore, not the States, ought to be 
represented in it." He adhered to the idea of popular representation in the Senate as well as the House, and thought senators might be appointed by electors chosen by the people, or by their legislature. The local views and feeling would " find their way into the general council, through whatever channel they may flow."

Before fixing the number of senators, they discussed their tenure of office, it being admitted that they should retire by classes in such a manner that the body should be more frequently renewed by fractions of its whole number. The terms of four, six, seven, and nine years, and during good behavior, were in turn suggested, the latter, however, failing of support. Gorham, of Massachusetts, and Wilson, of Pennsylvania, proposed the mean of six years, with biennial renewals of one third, which was carried by the votes of seven States against four.

Again was presented the question of the voting equality of States in the two Houses as the vital point of discussion, which, from the refusal of some of the members to accept any decision as final, had become not only threatening, but exasperating. When Rutledge now brought forward the subject, Martin, of Maryland, who seemed more persistent in presenting his own views than those of his State, directed 
his assault upon a point which perhaps more than any other had been decisively settled, that this general government was to operate upon individuals and not through the state governments. He went so far as to predict the defeat of the plan by the influence of Governor Clinton in New York. One heated speech produced others, and the strongest men of the Convention met in the fray. All discordant views, ranging from a continuance of the old federation to a solid government of the Union in which States should stand to the general government in the relation of counties to a State, found urgent and sometimes passionate expression. It was afterwards written of that time by one of the participators in the debate, that the Convention was on the verge of dissolution, scarcely held together by the strength of a hair. It was then that the aged Franklin urged his colleagues to invoke publicly and daily the aid of the Almighty, that they who labored to build the house might not build in vain.

On the following days the debate proceeded with more moderation. Gorham said, impressively, "A union of the States is necessary to their happiness, and a firm general government is necessary to their union." "The States," said Madison, in reply to the claim that they each became sovereign by the acquisition of 
their independence of England, - " the States never possessed the essential rights of sovereignty; these were always vested in Congress. Voting as States in Congress is no evidence of sovereignty. The State of Maryland voted by counties: did this make the counties sovereign? The States, at present, are only great corporations, having the power of making bylaws not contradictory to the general Confederation." Hamilton asked if each citizen of Delaware would have less liberty because each citizen of Pennsylvania had an equal vote with him. He said the contest was for power, not for liberty. It was then settled, for the last time, that in the first branch the voting should be in the ratio of population; and, as to this House, equality of state suffrage was abandoned, though the vote stood six to four, with Maryland divided.

In the same improved temper the Convention continued the debate upon the voting power of States in the Senate. Many of the members recognized in the country a wealthy class and a poor class, a gentry and a commonalty, and remembered that in most if not all of the States at that time there was a property qualification. These claimed, some that the Senate should represent the aristocratic classes, as the other House did the democratic; some that it should be so composed as to re- 
present the interests of property, which would not find a defence in the popular branch. Both had their influence in taking the election of senators from the people and vesting it in the legislatures, and also in restricting the number of that body. Madison maintained there was no danger to individual States, but there was danger between North and South from difference of climate, and especially from the existence of slavery; and was inclined to provisions which should give the South advantageous powers of defence against the North. Some new propositions, with confusion and excitement, again crept into the discussion before the vote was taken on equal suffrage of the States in the Senate. This vote was now again taken, and resulted in a tie, Georgia being divided in order to save the bad effect upon the Convention of a final defeat of the smaller States.

Charles Cotesworth Pinckney then recurred to the suggestion of Franklin for a compromise, and moved the appointment of a grand committee, with a delegate from each State, to report a measure covering both branches of the legislature. Roger Sherman indorsed it, saying, "Such a committee is necessary to set us right." The committee was appointed, and consisted of Franklin, Gerry, Ellsworth, Yates, Paterson, Bedford, Martin, Mason, Davie, and 
Baldwin. It signified a compromise, for which, in fact, the Convention was prepared, because they knew that New Hampshire and Rhode Island, if present, would convert the minority into a majority. The discussion had clearly proved that it was not really a question of safety to States or liberty to individuals, but a question of relative power between States in legislation affecting their respective interests. As such it must be in some manner compromised, and the Convention gave three days to the exclusive service of the committee by an adjournment for that period.

Franklin had observed the course of the debate with equal eyes, and no proposition emanating from him could be regarded with suspicion. He was always moderate, always sincere. The committee under his guidance proposed (I) one member in the first House for every forty thousand inhabitants, including all free persons and three fifths of other persons; (2) each State to have an equal voice in the second branch; (3) the first branch alone to have the power to originate taxes and appropriations.

Immediately on presentation of this report it was assailed by Wilson and Madison, the champions of proportional representation, by Butler, and by Gouverneur Morris. The latter said, "State attachments and state importance 
have been the bane of our country. We cannot annihilate the serpents, but we may perhaps take out their teeth. . . . Property, not liberty, is the main object of society. The savage state is more favorable to liberty than the civilized, and was only renounced for the sake of property." Numbers alone, in his opinion, could not furnish a just rule of representation. Rutledge confirmed the statement that "property was certainly the principal object of society." The report was more quietly, but firmly, defended by Ellsworth, Gerry, and Mason. The last said, wearily, "I will bury my bones in this city rather than expose my country to the consequences of a dissolution of the Convention without anything being done." Rufus King said, "Property is the primary object of society, and in fixing a ratio ought not to be excluded from the estimate." Butler pronounced "property the only just measure of representation." Wilson denied that it was the sole or even primary object of government and society. "The improvement of the human mind is the most noble object." And so the question of ratio of representation in the popular branch was, on motion of Gouverneur Morris, again referred, this time to a special committee of five. In addition to the proposer, Gorham and King, both of Massachusetts, with Randolph and Rutledge, were appointed on the committee. 
The report of this committee of five was confusing to all sides. It proposed fifty-six members of the first branch, at the first election, and apportioned them among the States in such manner as to give twenty-six to the Southern States and thirty to the Northern. It next provided, in view of progressive changes in wealth and numbers, that the general legislature be authorized to augment the number from time to time, and also to fix the number, in case of the organization of new States, on the basis of their wealth and number of inhabitants. Here was formally introduced the principle of the representation of wealth. That principle was then adopted, nine States against two, but was not destined to remain. After further reference of the first clause to a grand committee, the Convention accepted their report upon it, which changed the number of the first House from fifty-six to sixty-five, and in a proportion which gave the Southern States thirty and the Northern thirty-five members, and ratified it by a vote of nine States against two.

In respect to future and increased representation from old and new States it was contended, on the one hand, that the Atlantic States should always retain a majority of representatives over the growing West, which might otherwise by its numbers overrule their 
interests; and, on the other, that the Southern States would yet have "three fourths of the people of America within their limits;" and some uniform standard of enumeration should be established which would assure to them a right to proportionate representation. All the States, including the Western, must be treated as equals, and no distinctions were admissible, according to Randolph and Madison. Enumeration of population, said others, would be a sufficient indication of relative wealth. The question became commingled with that of slavery and that of direct taxation, and involved, also, that of relative political power in States and between different sections of the Union, and produced a long and sharp debate. In the end they fell back on the taxing rule which had been once adopted, and which based popular representation on the number of free inhabitants, with three fifths of the slaves; and the Convention added a decennial census to regulate the increase of representation in the future. New States were to be governed by the same standard.

The question of the Senate was at last regulated by an agreement that each State should be represented by two senators, "who shall vote per capita." Two opposite political objects were secured by this last senatorial adjustment. The States had an equal representation, as the small 
States demanded; but the individuals voted, as the large States desired, and not the States, thus preserving the national principle. The state legislatures became simply electoral bodies to provide national senators. It passed by nine votes against Maryland alone. Thus terminated a contest which at one time threatened to defeat all the efforts of the Convention for a more perfect Union. The effect of this adjustment was the pacification of the small States, whose delegates largely changed their attitude from hostility to friendship in their relation to the national plan of government. Only once more was their alarm excited. Two days before the Constitution was signed the mode for amending the Constitution in the future was established. It could be amended by a vote of three fourths of the States. Again the small States murmured, fearing hidden dangers to their one right of equality. Their strongest opponent, Gouverneur Morris, thought their apprehensions should be quieted, and moved the proviso "that no State, without its consent, shall be deprived of its equal suffrage in the Senate," which was at once adopted without debate or opposition. 


\section{VII}

THE DEBATE ON THE JUDICIAL ORGANIZATION

UpoN the question of establishing a national judiciary the progress of the Convention was less difficult. The tenure of the judges during good behavior and their security from legislative dictation by making their salaries permanent were agreed to without opposition when first presented in the Virginia plan. Later, in view of changes in money value and in society itself, increase of salary was allowed, but no reduction. The creation of inferior national tribunals was left ultimately to the discretion of Congress, since a part of the Convention were disposed to make the Supreme Court only a court of appeal from the state tribunals in cases where it should appear that national interests were involved.

The establishment of inferior courts was opposed by Butler and Martin, who believed them unnecessary and calculated to stir up the jealousies of state tribunals, with whose jurisdiction they will interfere. It was advocated by Gorham, Randolph, Gouverneur Morris, and Mason, who were unwilling to trust state 
courts with the administration of national laws. The general and local policy would often be at variance. Circumstances not now foreseen might render the power absolutely necessary. Sherman was willing to give the power, but hoped for the use of the state tribunals whenever possible. The power to create them was granted to Congress without a formal division.

Touching the jurisdiction of the courts, Mr. Madison proposed that it "extend to all cases arising under the national laws, and to such other questions as may involve the national peace and harmony," and this principle was adopted without opposition. The extent of its jurisdiction was afterwards more carefully defined, yet remained so large as in the sequel to cause some apprehension to the States, which made it later the subject of the eleventh amendment, adopted in 1798 . This amendment removed from their possible jurisdiction all suits brought against a State by citizens of any other State or of a foreign country.

James Wilson and Gouverneur Morris advocated the appointment of judges by the executive alone; John Rutledge and Charles Cotesworth Pinckney, by the legislature; Madison, Randolph, Sherman, and Martin, by the Senate. Gorham recommended their appointment by the executive, with the advice and 
consent of the Senate, which had been long the practice in Massachusetts and had worked with satisfaction. Sherman thought the judicial appointments should be diffused among the States, and the Senate would be more likely to do this than the executive. Mason said if the judges were to try impeachments of the executive they ought not to be selected by him. Gouverneur Morris did not want the Supreme Court to try impeachments. Being at the seat of government they might be drawn into intrigues with the legislature and even be previously consulted in the interest of the prosecution. This provision was then struck out of the scheme.

It was proposed to make the judges removable by the executive on application of the two Houses of Congress; but it had only the support of Connecticut and was rejected. This removal, it was decided, could only be made by regular process of impeachment, as in the case of all civil officers of the government.

As reported by the Committee of Detail the judicial clause did not give jurisdiction of cases " arising under this Constitution," but only to those "arising under the laws of the United States, and treaties," etc. The learned Dr. Johnson moved to insert the former clause. Mr. Madison objected to the enlargement, fearing it gave a general right of expounding the 
DEBATE ON JUDICIAL ORGANIZATION 95

Constitution beyond cases of a judiciary nature. But the Convention accepted it without further dissent, considering that it would in application be limited to cases "of a judiciary nature." 


\section{VIII}

ORGANIZATION OF THE EXECUTIVE POWER

IT will be remembered that the Virginia plan proposed the election of the executive authority, however it might be composed, by the national legislature. When that question came up for debate on June 2, Mr. Wilson offered a resolution for the election of the executive magistracy by electors, who were to be chosen by the qualified voters of districts into which the States should be divided; and all these electors so chosen should assemble and make the final election, being themselves ineligible to that office. Only Pennsylvania and Maryland supported him ; and the eight other States supported Mr. Randolph's proposition for the election by the national legislature, though it was opposed by Mr. Gerry. All were then doubtful whether the executive should be single or plural, being mindful, on the one hand, of the exercise hitherto of executive functions by a plural committee designated by the Congress; and, on the other, of the aspect of monarchy, in many eyes, if a single person should be invested with the authority.

Dr. Franklin wished that the executive 
should have no compensation, but his expenses should be paid. He feared to combine both ambition and avarice - love of power and love of money - in the same person. He did not act from a desire to save the amount of the salary, but to leave no personal motive in seeking the place except the love of honor and the public service; and he recalled the great example of Washington as commander-in-chief. He was heard with great respect, but without conviction, and with a feeling that his proposal was impractical.

Mr. Dickinson and Mr. Bedford desired the executive to be removable by the national legislature on request of a majority of the state legislatures. Mr. Mason held this to be a "violation of the fundamental principles of good government," in which Mr. Madison and Mr. Wilson concurred. Delaware alone supported it.

Mr. Wilson moved that the executive consist of a single person, and Mr. Charles Pinckney supported him. Great shyness, said Mr. Rutledge, was exhibited by gentlemen in taking position on that question, for the motion was followed by a significant silence. For himself, he preferred one man, because "a single man would feel the greatest responsibility, and administer the public affairs best;" but he would not give to him the powers of peace and war. 
Mr. Sherman would leave the number of the executive to the legislature, by whom they ought to be appointed from time to time as they thought best. It was the legislative will that was to be executed, and the executive should be accountable to it alone. Mr. Gerry would annex a council to the executive, and thought a legislative election would cause perpetual intrigue. Mr. Randolph strongly opposed a single executive, which "he regarded as the fœtus of a monarchy." Mr. Madison, observing the apprehensions of monarchical authority in the minds of members, wisely suggested that before decision on this point the Convention should define the powers to be intrusted to the executive. So they proceeded to this, and to the other question of method of appointing the executive; and Mr. Wilson still desired in some manner an election by the people, as was the case of governors of the States. Mr. Sherman still insisted that a removal of the executive from dependence on the legislature was "the essence of tyranny." Mr. Gerry suggested his appointment by the executives of the States.

Then they passed to the question of the term of office, for which Mr. Wilson proposed three years, with reëligibility, supported by Mr. Sherman, who was against rotation "as throwing out of office the men best qualified 
to execute its duties." Mr. Mason was for seven years and non-reëligibility, fearing "intrigue with the legislature for reappointment." Mr. Bedford was for three years, and ineligibility after nine years.

Seven years was accepted by New York, New Jersey, Pennsylvania, Delaware, and Virginia, against Connecticut, North Carolina, South Carolina, and Georgia, with Massachusetts divided; and the principle of ineligibility a second time was agreed to by seven States against Georgia and Connecticut, with Pennsylvania divided. On the motion of North Carolina, the executive was made removable by impeachment for certain causes.

Debate being resumed on the number of the executive, Messrs. Rutledge and Charles Pinckney, supported by Butler, were earnest for a single executive, because he would be more impartial, being responsible to the whole. With three, there would be a constant struggle for local advantages. Mr. Butler had seen its evil effects in Holland. But Mr. Randolph was wholly against unity in the executive, which would fail to win that general confidence which three persons from different parts of the country would inspire. It was the semblance of monarchy. Mr. Wilson again advocated the unity with powerful arguments, and denied its alleged unpopularity, affirming that the people 
were accustomed to it in the head of their state governments. The sturdy Sherman was inclined to agree with him, but wanted to associate a council, to make it more acceptable.

A single executive was finally agreed to by seven States, against New York, Delaware, and Maryland, after much argument and citation from other countries and other times.

The Virginia clause relating to a council of revision was taken up and severely criticised; and the whole question of a revisionary power over legislative enactments - of an absolute and of a qualified veto - was searchingly examined. Convincing objections were offered to the participation of the judiciary in such revision, which was desired by New York, Virginia, and Connecticut. It was claimed that the judiciary should be free to construe the laws, without incurring a bias by intervention in the making of them. Mr. Gerry and Mr. King, instead of a council of revision, would give the executive a negative on all laws, but subject to be overruled by a large majority of the legislative body. Mr. Wilson believed an absolute negative necessary for the self-defence of the executive, without which "the legislature can at any moment sink it into non-existence." Mr. Hamilton was of the same opinion, and, for evidence that its excessive use need not be feared, remarked that the power had not been 
used in England since the Revolution. Mr. Sherman could not give power to one man to override the will of the whole. Mr. Butler also resisted the absolute negative. Mr. Bedford was opposed to every check on the legislature. Mr. Mason appealed to fears of what would practically be an elective monarchy, and thought it would be sufficient if the power was given to "suspend offensive laws till they shall be coolly reviewed, and the objections overruled by a greater majority than that necessary to pass them in the first instance." Dr. Franklin also interposed his voice against the absolute negative, and feared the increase of executive power "till it should end in monarchy," and favored a qualified negative. At the close of the committee's debate on this point all ten States voted against the absolute veto. At last, and after further debate, the Convention accepted Mr. Gerry's motion for an executive veto, with power in two thirds of the legislature to overrule it, Connecticut and Maryland voting no; and it so passed into the Constitution.

Recurring to the mode of electing the executive, the Convention refused to adopt Mr. Gerry's motion for his election by the state executives, leaving it unsupported by a single State. On the $\mathrm{I} 7_{\text {th }}$ of July, after a long and exciting debate over the constitution of the Senate, the question of the executive was again 
resumed by the Convention. It was now agreed without dissent that it should consist of a single person. His election by the national legislature was, however, strenuously resisted. Gouverneur Morris argued that in that case " he would be the mere creature of the legislature." His election would be "the work of intrigue, of cabal, and of faction; it will be like the election of a pope by a conclave of cardinals; real merit will rarely be the title to the appointment." The citizens should elect him. Roger Sherman thought "the sense of the nation would better be expressed by the legislature than by the people at large, who would generally vote for some man from their own State." In this view he was supported by Charles Pinckney, by Mr. Mason, who thought it as wise to "refer a trial of colors to a blind man," as this election to the people; and by Dr. Williamson, of North Carolina. Mr. Wilson supported Mr. Morris; but they were for the time defeated by a vote of nine States against Pennsylvania. Mr. Martin, of Maryland, moved his election by electors appointed by the state legislatures, which proposition then received only two votes. The election by the national legislature was still allowed to stand, and his powers were next considered.

The executive was charged with the execution of "the national laws," and authorized 
ORGANIZATION OF EXECUTIVE POWER IO3

"to appoint to offices in cases not otherwise provided for" without opposition.

On the question of his non-eligibility for a second term of office, as proposed in the Virginia scheme, Gouverneur Morris said "it tended to destroy the great motive to good behavior, - the hope of being rewarded by a reappointment. It was saying to him, 'Make hay while the sun shines." This provision was then struck out by a vote of six States against Delaware, Virginia, and North and South Carolina.

On the question of a term of seven years, Mr. Broom, of Delaware, in view of the fact that the executive would now be reëligible, moved to reduce the term. Dr. McClurg, on the contrary, to rescue him from a constant and servile dependence on the legislature electing him, moved a term "during good behavior." Gouverneur Morris gladly seconded him, saying, "This was the way to get a good government," and Mr. Broom concurred. Roger Sherman opposed it: "If he behaves well, he will be continued; if otherwise, displaced; this was equivalent to a term during good behavior;" and he was supported by Mr. Mason. Mr. Madison said, "Experience has shown a tendency in our government to throw all power into the legislative vortex. The executives of the States are little more than ciphers, the legis- 
latures omnipotent." The executive should not be dependent on the legislature.

Dr. McClurg's motion was lost by the votes of Massachusetts, Connecticut, Maryland, North Carolina, South Carolina, Georgia (6), against New Jersey, Pennsylvania, Delaware, Virginia (4). "But the affirmative vote," says Mr. Madison," was given from motives of expediency rather than conviction, in order to force some mode of rendering him independent of the legislature."

On the Igth of July the question again recurred on the reëligibility of the chief magistrate, and mingled with it the mode of his election. Gouverneur Morris made a vigorous and impressive argument for greater independence in the executive. Recalling the maxim that republican government is not adapted to a large extent of country, because the executive magistracy cannot reach the extreme parts of it, he said, "Our country is an extensive one. We must then either renounce the blessings of the Union or provide an executive with sufficient vigor to pervade every part of it." "The legislature will continually seek to aggrandize and perpetuate themselves." "The executive magistrate should be the guardian of the people, even of the lower classes, against legislative tyranny, - should be the great protector of the mass of the people." He saw "no alter- 
ORGANIZATION OF EXECUTIVE POWER IO5 native for making the executive independent of the legislature but either to give him his office for life or make him eligible by the people." Mr. Randolph was moved to acknowledge that if he was reëligible by the legislature he would be no check on them : he would court a reappointment. His revisionary power over laws would be of no avail. He would therefore make him ineligible to a second term instead of providing another mode of election.

Mr. King was much struck by Mr. Sherman's observation, that "he who has proved himself most fit for an office ought not to be excluded by the Constitution from holding it;" and he preferred another plan of election. Mr. Paterson agreed with Mr. King, and proposed an election by electors to be chosen by the States. Mr. Wilson was glad to see the idea of a mediate or immediate popular election gaining ground. Mr. Madison thought there was equal or greater reason "why the executive should be independent of the legislature than why the judiciary should be." Mr. Gerry would have him chosen by electors selected by the state executives. "The people of the States will then choose the first branch, the legislatures of the States the second branch of the national legislature, and the executives of the States the national executive. This would form a strong attachment in the States to the national system." 
On the motion to reconsider the question it was carried unanimously. Mr. Ellsworth then moved for electors to be appointed by the state legislatures. The clause providing for electors was carried by Connecticut, New Jersey, Pennsylvania, Delaware, Maryland, and Virginia (6), against North Carolina, South Carolina, and Georgia (3), with Massachusetts divided. The clause for their appointment by the state legislatures received eight votes, against Virginia and South Carolina. The effort to make the executive ineligible to a second term now failed, only North Carolina and South Carolina supporting it. All this was followed by a change of front on the question of length of term, which had been fixed at seven years. Connecticut, South Carolina, and Georgia still supported it, and North Carolina and Massachusetts were divided; but the rest were against it. Mr. Ellsworth proposed six years, and was supported by Dr. Williamson. It was adopted by all other States against only Delaware.

It was first proposed by Mr. Gerry to allot from one to three electors to the States, according to their importance. But Dr. William. son, of North Carolina, thought that in future elections the electors should be according to the number of state representatives in the first branch of the national legislature. Mr. 
Gerry's ratio was adopted, six States to four, only to be afterwards changed. And they proceeded to consider the liability of the executive to impeachment.

It was contended on the one side that he ought to be exempt, because if he did wrong he would have coadjutors who could be punished, and if reëlected it would be proof of his innocence. It would render him dependent on the impeaching authority. On the other side it was claimed nobody could be permitted to be beyond the law and above justice. The principal, as well as coadjutors, should be punished. Dr. Franklin thought the clause was favorable to the executive, because, without it, here as in the Old World, if not legally removable, resort might be had to assassination, which would shut off all opportunity to prove his innocence, which he might do in case of impeachment. Gouverneur Morris thought the causes of impeachment ought to be enumerated and defined. Mr. Madison said the executive might lose his capacity, be guilty of negligence or perfidy, and the community should have a defence against these chances. His "incapacity or corruption might be fatal to the republic." Mr. King feared "an extreme caution in favor of liberty might enervate the government they were forming." "Under no circumstances ought he to be impeachable by the legislature, as 
this would be destructive of his independence." Gouverneur Morris admitted he ought to be impeachable for treachery, bribery (Charles II. had been bribed by Louis XIV.), corruption, and incapacity. But it should be by a mode not making him dependent on the legislature. And the liability to impeachment was carried in the affirmative by eight States, against Massachusetts and South Carolina.

It was then unanimously agreed that he should have a fixed compensation, to be paid out of the national treasury, New Jersey alone voting against the latter clause; and with unanimity that no elector should be eligible to the chief magistracy, nor be a member of the national legislature, nor an officer of the national government. It was further agreed the electors should be paid out of the national treasury for their services.

Another effort was made by some of the very ablest men in the Convention to associate with the chief magistrate the judges, as a council for the revision of laws. Mr. Madison renewed the expression of his fears that "the legislature would still be an overmatch" for the two other departments of the government, as there was " a powerful tendency in the legislature to absorb all power into its vortex. This was the real source of danger to the American Constitution." Mr. Gorham, on the contrary, 
ORGANIZATION OF EXECUTIVE POWER IO9 said, "Judges were not presumed to possess any peculiar knowledge of the mere policy of public measures." He thought it only necessary, at most, "to authorize the executive to call on the judges for their opinions." Mr. Gerry and Mr. Strong agreed with him, and Mr. Martin joined in this opposition. After able argument and much contrariety of opinion between States and in their delegations, the motion failed by four States voting no, three aye, two divided, and one absent.

Upon reconsideration of the resolution providing for electors, there was again a protracted debate, which seemed more to disintegrate than consolidate opinions. Dr. Williamson would go back to the first proposition for election by the national legislature, with ineligibility for a second term. "It was pretty certain that we should at some time or other have a king ; but he would omit no precaution to postpone the event as long as possible." Mr. Gerry proposed a refining process, that state legislatures should vote for the national executive by ballot, in proportion to the assigned electoral votes; failing of election by a majority, the first branch of Congress to choose two out of the four major candidates voted for; and from these two the Senate to choose one. Mr. Wilson thought to solve their perplexities by electing him for six years, the elective body being 
(say) fifteen persons chosen out of the national legislature by lot, and to retire immediately for the election to avoid intrigue, and not to separate without an election: but the best mode was a resort to the people. No progress was made to a concentration of opinion. $\mathrm{Mr}$. Mason laughed at an election of President by " a lottery." These and other propositions were voted down. Mr. Madison observed, "There were objections against every mode that had been, or perhaps could be, proposed," and reviewed the various possible methods of election, with the conclusion that the only safe alternatives were an election by the people, or by electors chosen by the people. Mr. Mason and Mr. Butler admitted the danger of foreign influence, and of cabals, in the case of election by the national legislature, and the latter was against reëligibility in any case.

Gouverneur Morris, on the contrary, was very positively against rotation in office. "It formed a political school in which we were always governed by the scholars, and not by the masters." Then it was suggested that every voter should vote for plural candidates, not more than one of whom should be a citizen of his own State, in which case the second choice of each might be the best choice of all. Dickinson thought the election by the people was "the best and purest source." Mason 
thought it best to return to the original plan, and despairing of more unanimity on any new proposition, the Convention reinstated it, and it went in that form to the Committee on Detail.

This committee reported accordingly that the executive should have the style "The President of the United States," and should be elected by the legislature by ballot. (The title of President was then borne by Franklin as chief magistrate of Pennsylvania.) Attention was called to the necessity of inserting the word " joint" before ballot, or the two Houses might negative each other's choice; and it was inserted. The motion to take the vote by States was defeated; the motion requiring a majority of personal votes was adopted, ten States to one. Then the old question of Presidential electors was again raised and argued, and only failed by an equality of votes, four to four, two divided, and one absent. The question was subsequently referred to a committee of eleven, who reported a plan which tended to concentrate opinions. It fixed his term at four years, with reëligibility, and provided for electors to be selected in each State as its legislature should direct, and equal in number to its total representation in the two Houses of Congress. They were to vote in their respective States, and not in a general college as at one time proposed. 
Thus they were removed from foreign influence, from the danger of cabals and intrigues; and this mode left the President independent of the legislature, while the term was so short as to prevent usurpation of power for personal objects, and went far to obviate objections before made to his reëlection. There were still criticisms, but this method finally prevailed and was inscribed in the Constitution. Upon no other subject did the opinion of the Convention so often sway to and fro as upon this. But the experience of a century has, in the main, justified the system, saving, perhaps, the duration of the term fixed at four instead of six years.

On the point of reëligibility there has never been any answer to the old question, Why should not the people be allowed to reëlect a good officer satisfactory to them in the administration of his office? And the term of four years was fixed because of this reëligibility. On the other hand, there has never been a satisfactory answer to the other old question, How can the selfish desire for a reëlection be prevented from influencing the public conduct of an officer if he is reëligible? And there seems to be no answer which involves less than a change in the nature of man. The fathers limited as far as possible the selfish motive by confining it to actions which would 
ORGANIZATION OF EXECUTIVE POWER II3 benefit the majority of men, and which should be favorable to their interests as the great constituency which could give or refuse the reëlection. At the same time, his conscience was subjected to his ambition in respect to actions which should excite popular clamor or applause. 


\section{IX}

\section{OTHER SPECIAL PROVISIONS OF THE CONSTITU'TION}

Until the Committee of Detail was appointed, the Convention had sought to confine their discussions to the outline of organization and to the broad principles of a government for the Union. The first battle, and that of the highest importance, had been fought for position. The fundamental question had been, Should the government be founded upon the States, or upon the people of the United States? Should it be a compact - a league - between sovereign States, as was the Confederacy, or should it be a single national government, extending behind the chartered States, and reposing upon the American people? It had been decided in favor of the united people; and that they, not the States, should constitute the new government, "to consist of a supreme legislative, executive, and judiciary."

The second vital struggle had been upon the two questions, How shall the local interests of the small States find protection in general legislation against the interests of the great States, represented as the latter would 
be by an immense numerical majority? How shall the greater wealth and population of the large States be secured against the practical control of the minority, if proportional representation is disallowed? These questions had been settled by giving the small States an equal representation in the second branch, and to the large States their proportional number of the first branch.

It had been further decided that both Houses should have the power to originate legislation. But as the power to tax and to regulate commerce had been the great argument of the more populous States in favor of proportional representation in both branches, it had been agreed by the smaller States, "that all bills for raising or appropriating money, and for fixing the salaries of the officers of the government, shall originate in the first branch, and shall not be altered or amended by the second branch ; and that no money shall be drawn from the public treasury but in pursuance of appropriations to be originated by the first branch."

It had been further agreed, touching the general powers of Congress, that they should have all the legislative rights before vested in the Confederacy; "and, moreover, to legislate in all cases for the general interests of the Union, and also in those to which the States are separately incompetent, or in which the harmony 
of the United States may be interrupted by the exercise of individual legislation."

The legislative acts of the United States, made by virtue and in pursuance of the Articles of Union, and all its treaties, it was declared, "shall be the supreme law of the respective States, as far as those acts or treaties shall relate to the said States, or their citizens or inhabitants;" "anything in the respective laws of the individual States to the contrary notwithstanding."

All these, together with other resolutions adopted, amounting to twenty-three in number, and representing all the solid results of the debates of the Convention since the $25^{\text {th }}$ of May, were, on the 26th day of July, referred to a "committee of detail," which had been selected by ballot, and was composed of Messrs. Rutledge, Randolph, Gorham, Ellsworth, and Wilson, two from the Southern and three from the Northern States, and all of them possessed of notable strength of intellect. The original propositions of Mr. Paterson, and of Mr. Charles Pinckney (of which latter no authentic copy remains) were referred to the same committee.

Their commission imposed on them the most important and laborious duty of translating these principles into detailed measures suitable for a constitution; and the Convention 
suspended its sessions until August 6th to leave the committee free for that work, which was to develop the vital germ of the republic.

In the report of this committee, made on the 6 th of August, the Constitution opened with the recital, "We, the people of the States of New Hampshire," etc., naming each of the thirteen States, "do ordain, declare, and establish the following Constitution for the government of ourselves and our posterity." The Committee of Revision afterwards struck out the names of all the States and established the clause, "We, the people of the United States, do ordain," etc. The name given to the government was "The United States of America." The two legislative branches were now called the House of Representatives and the Senate, and together were styled a "Congress." Each House was to choose its own presiding officer. Power was given to Congress to establish uniform qualifications of its members in regard to property. The representatives and senators were disqualified from holding any office under the United States during the time for which they shall respectively be elected, and senators also for one year afterwards. Their compensation was to be paid by the State in which they were chosen. The first House alone had the power of impeachment; the trial body to be the Supreme Court. 
The enumeration of legislative powers was very short, and on some of these limitations were imposed. No navigation act could be passed without the assent of two thirds of the members present in each House. No tax or duty could be laid on exports nor on the migration or importation of such persons as any State should permit to enter.

To the Senate was given the power to make treaties, and to appoint ambassadors and judges of the Supreme Court. They were also empowered - through elaborate provisions - to try and decide controversies between States which involved their respective jurisdictions or territory; and, further, to determine conflicting land-grants in certain cases. But this judicial function was later transferred to the Supreme Court.

To the States certain prohibitions were applied, including that against entering into any agreement or compact with another State, or emitting bills of credit, or making anything but specie a legal tender. In case of the admission of new States a vote of two thirds of the members voting in each House was required. These and other details opened a wide field for debate.

The Convention, upon hearing the report of the committee, adjourned to consider it before engaging in discussion. This draft of the 
Constitution provided for annual meetings of Congress on the first Monday of December, for which the Connecticut members were strenuous advocates. Mr. King thought it would not be necessary to meet every year. "A great vice in our system was that of legislating too much." Mr. Madison and Mr. Mason opposed fixing the time by the Constitution: it should be regulated by law. On Mr. Randolph's motion the words were then added, "unless a different day shall be appointed by law;" and on Mr. Rutledge's motion the Congress was expressly required to meet once in every year.

A question was raised on the clause which made the electors of the most numerous branch of the state legislature also qualified electors of the national House. Gouverneur Morris, Mr. Fitzsimons, and Mr. Mercer were in favor of restraining the suffrage to freeholders. Messrs. Ellsworth, Wilson, Mason, Rutledge, and Franklin were against it. "Give the votes to people who have no property," said Mr. Morris, "and they will sell them to the rich who will be able to buy them." Mr. Madison said, "Viewing the subject on its merits alone, the freeholders of the country would be the safest depositories of public liberty." Dr. Franklin thought it "of great consequence that we should not depress the virtue and public spirit of our common people" by ignoring their rights of 
suffrage under the general government. The clause was sustained by seven States against Delaware, with Maryland divided, and Georgia absent.

A representative was required to have been "a citizen in the United States for at least three years before his election." Mr. Mason "did not choose to let foreigners and adventurers make laws for us and govern us." The time was too short to give that local knowledge which a representative should have, and he moved to make it seven years. All the States agreed to this except Connecticut. The prior citizenship for senators had been fixed at four years. A term of fourteen years' prior citizenship was proposed by Gouverneur Morris. Mr. Pinckney said, in view of the treatymaking power, "there is peculiar danger and impropriety in opening the door to those who have foreign attachments. The Athenians made it death for any stranger to intrude his voice into their legislative proceedings." Were it not for the Revolutionary services of some who were alien-born, Mr. Mason would restrict eligibility to the Senate to natives only. Mr. Butler remarked on the danger of introducing "ideas of government so distinct from ours." Mr. Wilson and Dr. Franklin were against illiberality on this question. Gouverneur Morris, with his usual frank audacity, declared, "As to those 
philosophical gentlemen, those citizens of the world, as they called themselves, he owned he did not wish to see any of them in our public councils. He would not trust them. The men who can shake off their attachments to their own country can never love any other. These attachments are the wholesome prejudices which uphold all governments." At a later discussion, Mr. Mason expressed his fears that immigrants attached to Great Britain might work their way into our councils, and be pernicious in action upon commercial regulations. "The great houses of British merchants would spare no pains to insinuate the instruments of their views into the government." Various terms were proposed and voted down, until nine years was offered and adopted for the prior citizenship of senators.

Mr. Madison objected to the ratio of one representative for forty thousand inhabitants as, in the future, rendering that House a too numerous body. Mr. Gorham replied, "It is not to be supposed that the government will last so long as to produce this effect. Can it be supposed that this vast country, including the western territory, will, one hundred and fifty years hence, remain one nation?" And no prophetic voice answered him, that one hundred years after that Convention should adjourn the representatives of sixty millions of 
people, extending from the highest lake in the north to the mouth of the Mississippi, from the ocean on the east to the ocean on the west, from a doubled and redoubled extent of territory, with the terrible curse of slavery abolished from it all, should assemble around the building in which his hopeless inquiry was made, and celebrate in joy, in happiness, in prosperity, and in the hope of future centuries of union, the centennial anniversary of their great act!

Mr. Ellsworth attached his hopes to future alterations which might be made in the Constitution; and on motion of Mr. Madison and Mr. Sherman the ratio was made " not exceeding forty thousand," with the proviso that each State should have at least one representative. On the last day of the Convention General Washington for the first time addressed the Convention on any point of debate. It was to ask their unanimous support of an amendment, offered by Mr. Gorham, to substitute thirty for forty thousand. He requested it in order to conciliate those who feared to intrust the legislative powers to so small a body. The change was unanimously made.

Messrs. Pinckney and Rutledge did not like the clause which empowered Congress to overrule the States in their regulation of the times, places, and manner of holding elections for senators and representatives. Messrs. Gorham, 
Madison, and Gouverneur Morris sustained it as a necessary power to prevent abuses of their discretion by the States, false returns, defalcations of duty, improper voting districts, etc. Mr. King interjected the remark, "Although the scheme of erecting the general government on the authority of the state legislatures has been fatal to the Federal establishment, it would seem as if many gentlemen still foster the dangerous idea." The Convention on vote retained the power of both original and revisionary control over the States, except as to the place of choosing senators.

The same gentlemen proposed a fixed property qualification for the President, for judges, and for congressmen. Mr. Ellsworth and Dr. Franklin resisted it, both on principle and for expediency; and, on voting, the "no" was so general that the vote by States was not asked for.

The question of national control of the discipline of the state militia was referred to a "grand committee" of one from each State. Mr. Dickinson and others thought "the States never would nor ought to give up all authority over the militia." Mr. Butler and others thought it should be submitted to the authority which was charged with the general defence: the States would never secure uniformity of discipline or effectiveness of organ- 
ization. Mr. Gerry thought this the last point to be surrendered. "If it be agreed to by the Convention, the plan will have as black a mark as was set on Cain." This question, like many others, was settled on middle ground by giving to the United States the power to organize, arm, and discipline the militia, and to govern them when employed in the national service, leaving to each State the appointment of officers and the training of the force.

Gouverneur Morris also submitted several propositions organizing a Council of State to assist the President, consisting of the Chief Justice, a Secretary of Domestic Affairs, a Secretary of Commerce and Finance, a Secretary of Foreign Affairs, a Secretary of War, a Secretary of the Marine, and a Secretary of State, and outlining the duties of each. These went to the same committee, and were favorably reported, adding the Speaker of the House to the Council. But it was not approved by the Convention, which preferred individual responsibility, with only the aid of chiefs of executive departments.

Mr. Mason moved to insert a power "to enact sumptuary laws," with a view to the improvement of manners. It was briefly opposed by Ellsworth, Morris, and Gerry, and defeated, eight States to three.

The clause respecting treason was thought 
by Mr. Madison to be too narrow; that greater discretion should be given to Congress to define it. Gouverneur Morris was for giving to the Union "an exclusive right to declare what should be treason. In case of a contest between the United States and a particular State, the people of the latter must, under the clause as it stood, be traitors to the one or the other authority." Dr. Johnson contended that treason "could not be both against the United States and individual States, being an offence against the sovereignty which can be but one in the same community." The Convention decided without dissent to strike out of the clause what related to the States, leaving the definition to apply to the United States only. Upon reconsideration and further debate, the Convention came back to the same conclusion upon a divided vote, and leaving the point unsettled whether there could be a double treason, or that treason against a State was necessarily treason against the United States, and to be prosecuted as such.

In the article enumerating the powers of Congress, authority was given "to make war." Mr. Pinckney thought its proceedings would be too slow, its numbers too great; and that the Senate alone, being charged with foreign affairs as it was, would be the better repository of this power. Mr. Butler would vest the power 
in the executive, who "will not make war but when the nation will support it." Messrs. Madison and Gerry moved to substitute the words " declare war," for "make war," so as to leave the power in the executive to repel attacks; and this was agreed to.

Mr. Madison, ever full of forethought, and anxious that future events should not confront a defective Constitution, presented an enumeration of twenty-one additional powers in Congress, including the following:-

"To establish an university."

"To encourage by premiums and provisions the advancement of useful knowledge and discoveries."

"To establish seminaries for the promotion of literature and the arts and sciences," and institutions and rewards for promotion of agriculture, commerce, trades, and manufactures.

"To grant charters of incorporation."

All these were referred to the Committee of Detail, but were not reported.

Afterwards Messrs. Madison, Pinckney, and Wilson brought the question of the power to establish a university before the Convention by a motion to add this to the list of congressional powers. Gouverneur Morris replied, "It is not necessary. The exclusive power at the seat of government will reach the object." Upon the vote, Pennsylvania, Virginia, and the two Caro- 
linas were for giving the express authority, with Connecticut divided. But the other six States were against it.

\section{THE ELEMENT OF SLAVERY.}

It is not within the purpose of these historical notes to review that portion of the debates which relates to questions no longer of practical concern. The institution of slavery in many of the States interposed great obstacles, alike to the agreement of the Convention upon a Constitution, and to its ratification by the States. It is known to all that it continued to be a source of discord also in the Union until, seventy-five years later, it nearly caused the dissolution of the Union itself which had been created with so much patriotic toil and devotion. Its disappearance from our continent is therefore a new element of happiness for us which was denied to our constitutional fathers; and justifies more faithful hopes of the perpetuity of the Union which they founded.

INCORPORATIONS AND INTERNAL IMPROVEMENTS.

Dr. Franklin, mindful of the need of connecting and improving communications by water routes, moved to add the power "to provide for cutting canals where deemed necessary." Mr. Sherman objected, that the expense would fall on the United States, the benefit 
accrue to the localities. Then Mr. Madison proposed to enlarge it into a power "to grant charters of incorporation, where the interest of the United States might require, and the legislative provisions of individual States may be incompetent." He desired to facilitate communication between the States. "The political obstacles being removed, a removal of the natural ones as far as possible ought to follow." Mr. Randolph seconded him.

Mr. King thought the power unnecessary. Mr. Wilson thought it " necessary to prevent a State from obstructing the general welfare." Mr. King replied that the States would be divided into parties by the proposition. In Philadelphia and New York they would refer it to the establishment of a bank, about which the two cities were in contention. Elsewhere it would be referred to mercantile monopolies.

Mr. Wilson spoke of the importance of canals to reach the Western settlements. "As to mercantile monopolies, they are already included in the power to regulate trade." On this last point Mr. Mason differed from Mr. Wilson, and was for limiting the power to the single case of canals. The question was first taken upon the authority for canals; this being refused by all the States except Pennsylvania, Virginia, and Georgia, the whole clause was dropped. 
And with this short debate, the entire question of schools and universities, of canals, highways, internal improvements, with countless millions of money involved, and of all chartered corporations, was left to the future interpretation of the other powers granted to Congress. The necessities of the country, developed by its growth and by the discovery of steam-power applied to locomotion, have forced an enlarged construction of the Constitution in the line indicated by the remark of $\mathrm{Mr}$. Wilson, and rejected by Mr. Mason. These two statesmen unwittingly became the founders of two rival schools of Constitutional interpretation, whose disputes have had no end, though that of Mr. Wilson has prevailed in the legislation of Congress.

\section{IMPEACHMENT.}

It was first decided by the Convention to give the Supreme Court the trial of all impeachments of public officers. But after giving to the executive the power of appointment of the judges, it was argued that his influence over that court would be too great, and that the chances of intrigue must be avoided; and the trial of impeachments was transferred to the Senate.

Here again it was objected, that as the VicePresident, presiding over the Senate, would 
succeed upon conviction of the President, he was directly interested in the result. To obviate this serious obstacle it was provided that on such trial he should leave the chair, and the Chief Justice should preside. In order further to remove objection to the trial of the executive by a mere political body, a judicial character was given to them for this emergency, by requiring that in this capacity the senators should be under special oath.

This settlement was made only after many expressions of conflicting opinions, and much uncertain debate, during which the Convention seemed to be feeling its way to a wise conclusion.

NATIONAL CONTROL OVER STATES IN THE

ELECTION OF MEMBERS OF CONGRESS.

In framing the details of the Constitution the committee reported this clause: "The times and places and manner of holding the election of members of each House shall be prescribed by the legislature of each State; but their provisions concerning them may at any time be altered by the legislature of the United States."

Upon its consideration in Convention, Messrs. Pinckney and Rutledge moved to strike out the last clause, which gave revisionary control to Congress.

Mr. Gorham said: "It would be as improper 
to take this power from the national legislature as to restrain the British Parliament from regulating the circumstances of elections, leaving this business to the counties themselves."

Mr. Madison added stronger expressions : "The policy of referring the appointment of the House of Representatives to the people, and not to the legislatures of the States, supposes that the result will be somewhat influenced by the mode. This view of the question seems to decide that the legislatures of the States ought not to have the uncontrolled right of regulating the times, places, and manner of holding elections. These were words of great latitude. It was impossible to foresee all the abuses that might be made of the discretionary power. Whether the electors should vote by ballot, or viva voce; should assemble at this place or that place; should be divided into districts, or all meet at one place; should all vote for all the representatives, or all in a district vote for a member allotted to the district; these and many other points would depend on the legislatures, and might materially affect the appointments. Whenever the legislatures had a favorite measure to carry they would take care so to mould their regulations as to favor the candidates they wished to succeed. . . . It seemed as improper in principle, though it might be less inconvenient in prac- 
I32 EVOLUTION OF THE CONSTITUTION

tice, to give the state legislatures this great authority over the election of the representatives of the people in the general legislature as it would be to give the latter a like power over the election of representatives in the state legislature."

Mr. King supported Mr. Madison's views, calling attention again to the fact that they were not building this government on the basis of the state legislatures. He said: "If this power be not given to the national legislature, their right of judging of the returns of their members may be frustrated." To this Gouverneur Morris added that "the States might make false returns, and then make no provisions for new elections." Mr. Sherman did not know that it might be best to retain the clause, though he had confidence in the state legislatures.

The motion to strike out then failed, without a division, and it was not again contested.

In this, as in many other cases, is observed the steady development of the fundamental idea of national independence of all state action. Mr. Madison, above all others, kept it constantly in view. The process was like the steady emergence from the world of chaos of a world of order; of a central sun from a confused assemblage of stars, on which it would shed light, but from which it could receive none. The new 
central State to be evolved must control the elements and operations necessary to its own existence and efficiency.

COMPENSATION OF MEMBERS OF CONGRESS.

The report of the Committee of Detail provided for the payment of both representatives and senators by the States in which they were chosen. The original plan of Virginia simply proposed their payment by "liberal stipends," without designating the source of payment. On motion of Mr. Pierce, their wages were made payable out of the national treasury; and on motion of Dr. Franklin the word "liberal " was struck out.

When the debate again occurred on the Virginia resolutions, Mr. Ellsworth moved their payment by the States respectively. He observed that, owing to different styles of living and the different scales of compensation in the various States, what would be deemed only reasonable compensation in one State would be very unpopular in another. Dr. Williamson concurred with him.

Mr. Gorham was opposed to leaving the matter to the state legislatures, "who were always paring down salaries in such a manner as to keep out of office men most capable of executing the functions of them." He would not fix the grade of pay in the Constitution. 
"Let the national legislature provide for their own wages from time to time, as the state legislatures do." $\mathrm{He}$ had not seen and did not apprehend an abuse of this power. Mr. Randolph did not think it honorable in the Convention to sacrifice right to popular prejudice. Payment by the State would create a dependence which would vitiate the whole system. Mr. King was of the same opinion, as was also Mr. Wilson. But Mr. Sherman adhered to payment by the States.

Mr. Hamilton stoutly opposed "making the national council dependent on the legislative rewards of the States. Those who pay are the masters of those who are paid." Payments by the States would be unequal, and there would be greater distance travelled by some than by others. Mr. Madison would not leave men coming "from beyond the mountains to the precarious and parsimonious support of their constituents." But he disliked to give the legislature the right to fix their own salaries, as being too much interested.

On Mr. Ellsworth's motion to strike out "national treasury," the vote stood ayes four, noes five, with New York and Georgia divided. The question was embarrassed by fears of inserting a fixed sum in the Constitution, on the one hand, and so run the double risk of its invariability in the future, and of its being obnox- 
ious to the States; and, on the other, of giving the members an authority to fix their own pay. The propositions which went to the Committee of Detail, therefore, were to pay representatives out of the public treasury, and that senators should be paid, without indicating by whom; and the report of that committee was that both branches should be paid by the States from which they received their appointments.

Upon recurring to the question on this report, Mr. Ellsworth frankly stated " that in reflecting on this subject he had been satisfied that too much dependence on the States would be produced by this mode of payment," and he moved to strike it out, and to substitute the United States treasury. Mr. Butler thought that senators would be so long out of their States that they would lose sight of their constituents, unless dependent on them for support. "On the other side," Mr. Gerry said, "the state legislatures may turn out the senators by reducing their salaries; such things have been practised."

Mr. Sherman was not afraid that the legislature would make their own wages too high, but too low; so that men ever so fit could not serve unless they were at the same time rich. Mr. Carroll was surprised at the report in favor of such complete dependence of both Houses. "The States can now say, If you do not comply 


\section{EVOLUTION OF THE CONSTITUTION}

with our wishes we will starve you ; if you do we will reward you. The new government in this form was nothing more than a second edition of the Confederate Congress, in two volumes instead of one, and perhaps with very few amendments."

Mr. Dickinson also desired Congress to be " independent of the prejudices, passions, and improper views of the state legislatures," but disliked leaving the pay to be regulated by Congress itself. There were also objections against taking a permanent standard as wheat, which had been suggested on a former occasion. He proposed a revision by legislative act every twelve years, "settling the quantum of their wages." Mr. Martin, always for reserved control by the separate States, thought senators, as state representatives, ought to be paid by the States. Mr. Carroll, his colleague, denied that the senators were designed to be advocates of state interests; on the contrary, they were to represent and manage the affairs of the whole.

The vote was then taken, and all the States except Massachusetts and South Carolina adopted the provision for paying the members of Congress out of the national treasury. An attempt to fix the sum per diem failed, and then the words "to be ascertained by law" were added without a division. 


\section{THE RIGHT TO TAX EXPORTS}

was warmly advocated on the one side, and as warmly resisted on the other. It was claimed on the one hand that this power might be a useful aid in negotiating commercial treaties, and such a tax, if imposed on certain articles which must be used abroad, would be paid by foreigners; that it might yet be necessary for revenue; that it might be required to encourage the manufacture of raw materials at home; and to prohibit it in all cases would be a dangerous denial of power to Congress in future contingencies. On the other hand, the "staple States" feared that its imposition on their leading articles of export might be accomplished by the votes of Northern States, and that the former might thus be made to pay an undue share of the taxes. The general government might through it oppress particular States. Mr. Madison especially insisted that it was a proper tax, that its use should not be allowed to the separate maritime States as a power to oppress their interior neighbors; and that the national legislature was the proper depository of this power. He thought it would be wise to employ it especially in taxing exports of articles like tobacco, which had no competition in foreign markets, - for in that case it would really be paid by foreigners. In the end, the fear of such use 
of the power as would prejudice the interests of particular States prevailed, and the power was prohibited alike to the States and to the United States.

\section{THE POWER TO REGULATE FOREIGN AND}

INTERSTATE COMMERCE.

The powers to levy taxes, duties, imposts, and excises, and to regulate commerce, were conferred upon the national government without giving rise to any serious difficulty, because the necessity of it was the strong motive to the new organization of government.

The question of taxation first arose in connection with the ratio of representation; and it was resolved by five votes against three, and one State divided, that until a census was taken, direct taxation should be imposed on the States according to representation in the first branch. When the Committee of Detail made their report on August 6th, the clauses giving Congress the power to tax, and to regulate commerce, appear in the identical language in which they are now found in our Constitution, except that the clause "but all duties, imposts, and excises shall be uniform throughout the United States" was afterwards added.

In the discussion on representation, Mr. King asked, "What is the precise meaning of direct taxation?" No one replied to his inquiry. A 
proposition to obtain by requisition from each State its quota of direct taxes failed, eight States to one, and Virginia divided.

In passing upon the words "duties" and "imposts," Mr. Martin asked what was meant by these words? Mr. Wilson replied that "imposts" was appropriated to commerce, while "duties" applied to a variety of objects, as stamp duties, etc. The only vote against the adoption of that taxing clause was Mr. Gerry's.

On the question of laying embargoes, Mr. Madison moved to prohibit that power to the States. Mr. Sherman thought they might need to exercise it "to prevent suffering and injury to the poor;" and Mr. Mason thought the amendment dangerous. Gouverneur Morris considered the provision unnecessary, "the power of regulating trade between State and State already vested in the general legislature being sufficient." Mr. Madison then moved an absolute prohibition against the laying of duties by States on imports, in order to exclude the possibility of their getting the consent of Congress to an act which would tax the imports of their neighbors passing through their markets. Mr. Mason objected that "particular States might wish to encourage, by import duties, certain manufactures for which they enjoyed natural advantages, as Virginia the manufacture of hemp," etc. Mr. Madison replied that "the 
encouragement of manufactures in that mode requires duties not only on imports directly from foreign countries, but from other States of the Union, which would revive all the mischiefs experienced from the want of a general government over commerce."

The power to regulate commerce was first given unanimously, and without any objection or query being raised upon its right or expediency. But on the 29th of August, Mr. Charles Pinckney, with special reference to the report of a committee which recommended the rejection of the clause requiring a two-thirds majority to pass a navigation act, moved a proposition that " no act of the legislature for the purpose of regulating the commerce of the United States with foreign powers, or among the several States shall be passed without the assent of two thirds of the members of each House." He classified the States according to their conflicting interests, to show the danger to these interests if a mere majority should be empowered to regulate commerce and navigation. The power was a pure concession, he said, on the part of the Southern States, which did not at present need the protection of the Northern States. Mr. Martin supported him. Charles Cotesworth Pinckney disagreed. Mr. Clymer said "the Northern and Middle States would be ruined if not enabled to defend themselves against for- 
eign regulations." Messrs. Sherman, Spaight, Gouverneur Morris, Rutledge, and others opposed the demand for a two-thirds majority. It was rejected by seven States against Maryland, Virginia, North Carolina, and Georgia; and the clause requiring two thirds to pass a navigation act was struck out, leaving this on the same plane with other legislation. The debate recognized the importance of a commercial marine, as fostering seamen, and as auxiliary to the navy. Mr. Mason, as late as September I 5, made an effort to require a two-thirds majority to pass a navigation act at any time before $\mathrm{i} 808$, apparently associating it with the slave trade; but only Maryland, Virginia, and Georgia supported the proposal.

This power having ever since remained undisputed, the real significance of the provision has been forgotten. The necessity of its existence in a central authority, which should bind all the States, was then strongly appreciated and universally understood. As colonies, they had always assented to the imposition of duties by Great Britain on foreign goods imported among them so far as was needed to regulate their commercial intercourse with foreign countries. Dr. Franklin, as colonial delegate in England, had expressly answered a parliamentary committee in 1766 that the colonies did not object to the British exercise over them of 
this power for the purpose of regulating commerce, but denied it and all other taxation when imposed with the object of obtaining a revenue. His answer was, "I never heard any objection to the right of laying duties to regulate commerce; but a right to lay internal taxes was never thought to lie in Parliament." Lord Chatham, a few days afterwards, in a speech upon the right of taxing America, admitted "there is a plain distinction between taxes levied for the purpose of raising a revenue and duties imposed for the regulation of trade." In 1778 the government introduced a bill in Parliament for the purpose of conciliating the colonies, then in open revolution, in the preamble of which they renounced all taxation of America, "except only such duties as may be expedient to impose for the regulation of commerce."

The experience of mutual injustice among the colonies in their imposition of duties to raise a revenue, and to regulate their rival trade with foreign countries, had led to a widespread regret that there was no common authority to regulate this commerce on terms of equality for all, as had before been done by act of Parliament. Each State was powerless to protect its own industries except by imposition of duties against importations from other States as well as directly from abroad. In August of the year prior to the meeting of this Convention a grand com. 
mittee of the Federal Congress had reported an article to be added to the Confederate system, which gave to the "United States in Congress assembled the sole and exclusive power of regulating the trade of the States, as well with foreign nations as with each other, and of laying such prohibitions and such imposts and duties upon imports and exports as may be necessary for the purpose;" with a proviso, however, that the amounts so collected by the United States should be paid to the use of the State in which they should be payable; and that citizens should not be required to pay more than foreign subjects.

It thus appears that the statesmen of that period - and some of the members of that committee were now members of this Convention - were thoroughly familiar with the system of regulating trade with foreign countries by the imposition of duties, and even went so far as to authorize "prohibitions" of such trade, or parts of it. In a debate in Convention (August I3) upon another subject, Mr. Madison said : "In many acts, particularly in the regulation of trade, the object would be twofold. The raising of revenue would be one of them. How could it be determined which was the primary or predominant one, or whether it was necessary that revenue should be the sole object, to the exclusion even of other incidental effects? When 
144 EVOLUTION OF THE CONSTITUTION

the contest was first opened with Great Britain their power to regulate trade was admitted, their power to raise revenue rejected." Mr. Mason had expressed his fears of foreign influence in our commercial regulations, that "the great houses of British merchants would insinuate the instruments of their views into our government."

In the debate on the ratification of the na. tional Constitution in the Massachusetts Convention, Mr. Thomas Dawes urged its approval because of the power it gave to the national government over commerce and navigation. He said: "For want of general laws of prohibition through the Union, our coasting trade, our whole commerce, is going to ruin." After reciting the free access to our ports of British bottoms, and their great earnings from American freights, he added: "Our sister States are willing that these benefits should be secured to us by national laws, but we are slaves to Europe. We have no uniformity in duties, imposts, excises, or prohibitions. Congress has no authority to withhold advantages from for. eigners in order to obtain reciprocal advantages from them. Our manufacturers have received no encouragement by national duties on foreign manufacture, and they never can by any authority in the Confederation. . . . The citizens of the United States within the last three 
years have contracted debts with the subjects of Great Britain to the amount of near six millions of dollars. If we wish to encourage our own manufactures, to preserve our own commerce, to raise the value of our own lands, we must give Congress the power in question."

In other States the object of this provision was equally well understood, as shown by the use made of it in the efforts to defeat the ratification of the Constitution in the States furnishing exports, but having no shipping and no manufactures.

In the light of all these debates we see clearly what was meant by the power "to regulate commerce with foreign nations and among the several States." In pursuance of this authority, after prescribing the oaths of office to be taken, the first act of Congress under this Constitution (chapter ii. Stats. at Large) imposes duties on foreign imports for the "twofold purpose" to which Mr. Madison alluded in the Convention, - "for the support of the government, for the discharge of the debts of the United States, and the encouragement and protection of manufactures," as recited in its preamble. All the great commercial countries of Europe at that time exercised the same power, and for the same twofold purpose. Wars were undertaken to secure exclusive colonial markets for their wares, and some of these govern- 
ments have continued that exclusive policy to this day. Without a like power this government would have been defenceless in negotiations of commercial treaties, and would have remained especially the commercial victim of that government from whose dominion it had just escaped.

Mr. Madison introduced the bill for the exercise of this power two days after the organization of the First Congress (April, r789, and before President Washington was inaugurated), proposing also a discriminating duty on tonnage to protect American shipping. He said in debate that the "interests of States which were ripe for manufactures ought to have attention, as the power of protecting and cherishing them has by the present Constitution been taken from the States, and its exercise thrown into other hands."

BILLS OF CREDIT AND LEGAL TENDER.

The Committee of Detail, under the authority giving to the new legislature all the powers of the Confederate Congress, reported the clause " to borrow money and emit bills on the credit of the United States."

Gouverneur Morris, seconded by Mr. Butler, moved to strike out the authority "to emit bills" of credit, holding it unnecessary if the public credit was good, and useless if it was 
bad. Mr. Madison inquired if it would not suffice to prohibit their being made a tender. Promissory notes in that shape might in some emergencies be best. Mr. Morris answered that without the clause the promissory notes of a responsible minister would be good. If paper emissions were not prohibited, the money interest would oppose the plan of government. Mr. Mason had a mortal hatred against paper money, but he was unwilling to tie the hands of the government against all emergencies. Mr. Gorham thought the authority was implied in that of borrowing, so far as it was safe and necessary.

Mr. Ellsworth thought it "a favorable moment to shut and bar the door against paper money." The mischiefs of it were fresh in the public mind, and keenly felt. "The power may do harm, never good." Mr. Butler remarked that paper money was not anywhere in Europe a legal tender; to which Mr. Mason replied, neither was the power denied in Europe. Mr. Read observed that the words, if not struck out, "would be as alarming as the mark of the beast in Revelation." Mr. Langdon would rather reject the whole plan than retain the obnoxious words.

They were struck out by vote of all the States (9) except New Jersey and Maryland. Mr. Madison notes that he was satisfied the omis- 
sion of the clause would not prevent the issue of public notes so far as safe and proper; and "would onlycut off the pretext for a papercurrency, and particularly for making the bills $a$ tender, either for public or private debts." (Madison Papers, vol. iii, p. I 346.)

When the question of the powers to be denied to the States was presented, Mr. Wilson and Mr. Sherman moved to insert, after the prohibition of coining money, the words " nor emit bills of credit, nor make anything but gold and silver coin a tender in payment of debts." Mr. Gorham hesitated, fearing to arouse the opposition of the States, and willing that the power should remain among those which might be exercised by the States "with the assent of Congress." Mr. Sherman would crush paper money at once. On that part denying to the States the right to emit bills, all the States voted to prohibit it except Virginia, with Maryland divided. Upon the prohibition against making anything but coin a legal tender, the opinion was unanimous.

Thus were the States forever prevented from again incurring for themselves the countless evils which they had already suffered from a forced paper currency. There is little doubt that the Convention also believed the Union to be saved from the same peril, when they struck out from the powers of the new national 
government that of emitting bills of credit. There is no trace in the recorded debates of the belief of a single member that under the power "to borrow money" the Congress could exercise the power of making their bills a legal tender for private debts. There is rather the contrary indication, that they considered this authority non-existent, unless it should be enumerated among the express powers granted. The authority as assumed in later years appears to have been an unwarranted deduction from the general power to provide for carrying into effect other powers which were granted. The Convention, while prohibiting the power to the States, supposed it sufficient to simply withhold the authority from the Congress of the United States.

\section{TREATIES AND THEIR FORCE.}

In distributing the powers to the various branches of the government, the Committee of Detail assigned to the Senate the power to make treaties, with the correlative power to appoint ambassadors. Mr. Hamilton's plan had proposed to invest this body with the power to declare war, while he associated it with the President in advising and consenting to treaties. But neither this nor any other plan, except that of Virginia, was made the basis of action, although traces of their provisions 
are seen in the motions made for amendment of the plan always under debate. It is doubtless true that some of the propositions made by Mr. Charles Pinckney and Mr. Hamilton, as well as of those in the New Jersey and Connecticut schemes, found adoption in the various amendments made to the original plan.

But this provision, giving the Senate the sole power over treaties, appears to have been accepted in the first instance by common consent. On August I5, Mr. Mason, while opposing another power of the Senate, observed they "could already sell the whole country by means of treaties." Mr. Mercer in reply said, "The Senate ought not to have the power of treaties. This power belonged to the executive department;" and added that treaties would not be final, so as to alter the laws of the land, till ratified by legislative authority, as was the case in Great Britain. Mr. Mason rejoined, that he " did not say a treaty would repeal a law, but that the Senate might by means of treaties alienate territory, etc., without legislative sanction; an example was found in the British cession of West India Islands by treaty alone. If Spain should take possession of Georgia, the Senate might by treaty dismember the Union."

Upon the direct consideration of this article, Mr. Madison observed that, as the Senate represented the States, and for other reasons as well, 
"it was proper that the President should be an agent in treaties." Gouverneur Morris doubted about referring to the Senate the making of treaties in any degree; but for the present would only move as an amendment, "but no treaty shall be binding on the United States which is not ratified by law." Mr. Madison spoke of the inconvenience of requiring a legal ratification of treaties of alliance in case of war, and in many other cases. Mr. Gorham called attention to "many other disadvantages if treaties of peace and all negotiations are to be previously ratified; and if not previously, the ministers would be at a loss how to proceed. American ministers must go abroad not instructed by the same authority which is to ratify their proceedings." Mr. Morris answered that the result would be that foreign governments must send their ministers here (for an alliance), which he desired. Mr. Wilson was inclined for the amendment. Without it "the Senate could by treaty require all the rice of South Carolina to be sent to one particular port." Mr. Dickinson concurred.

Dr. Johnson thought it a solecism "that the acts of a minister with plenipotentiary powers from one body should depend for ratification upon another body. The British king had full authority to make treaties and ratify them; and if Parliament refused to provide for carrying 
them into effect it was a violation of the treaty." Mr. Randolph thought best to postpone its further consideration, in view of the objections to the clause; but on this motion the vote was equally divided.

The question was then put on the amendment requiring ratification of treaties by law; and only Pennsylvania voted for it, North Carolina being divided, and eight States voted against it.

After adding "other public ministers" to ambassadors, the whole clause was postponed for further consideration and referred to the committee of five before appointed. Mr. Madison suggested a possible distinction in the mode of ratification between treaties eventual, or of alliance for limited terms, and other treaties; the former to depend alone on the President and Senate.

From another committee, charged with resolutions respecting the executive, on the 4 th of September, came a report in which this proposal was made: "The President, by and with the advice and consent of the Senate, shall have power to make treaties; " and in the same manner the appointment of ambassadors and other public ministers was transferred to him. But upon this power to make treaties was put the following limitation: "But no treaty shall be made without the consent of two thirds of the members present." 
Mr. Wilson, seconded by Mr. Fitzsimons, recalling the provision already adopted, that this Constitution, the laws under it, and treaties "shall be the supreme law of the land," moved to add to "the Senate" the words " and House of Representatives," so as to involve the whole law-making power as necessary to validate a treaty. "As treaties," he said, "are to have the operation of laws, they ought to have the sanction of laws also." He thought this outweighed the reasonable objection that secrecy was necessary in the business of making treaties.

Mr. Sherman averred "that the necessity of secrecy in the case of treaties forbade a reference of them to the whole legislature. The only question was, whether the power could be safely trusted to the Senate, and he thought it could be."

Then the vote was taken, and Pennsylvania alone supported Mr. Wilson. The other ten States voted for excluding the House of Representatives from participation in the making or ratification of treaties.

The clause requiring two thirds of the Senate for ratification was opposed by Mr. Wilson, as enabling a minority to overrule a majority. Mr. King concurred, because here was added the element of consent of the executive power as a security. Mr. Madison thought treaties of peace should be facilitated, and moved that 


\section{EVOLUTION OF THE CONSTITUTION}

only a majority be required for them; and it was unanimously agreed to. He then went further, to guard against Presidential ambition and love of power in time of war, and proposed that two thirds of the Senate might make peace without his consent. Mr. Butler concurred. Mr. Gorham thought this unnecessary, because the means for carrying on war were in legislative hands and might be refused. Gouverneur Morris added that the President, as general guardian of the national interests, was entitled to concur in the making of peace. Mr. Gerry thought there was perhaps more need of caution in treaties of peace than in other treaties, as fisheries and boundaries, etc., would be at stake; and so thought Dr. Williamson. Mr. Madison's motion was defeated by eight States against three.

Afterwards, Messrs. Williamson and Spaight recurred to the subject of the amendment which allowed treaties of peace to be made with consent of a majority of senators, and moved to require two thirds in case territorial rights were affected. Mr. King would extend it, then, "to all present rights of the United States." The next day Mr. King moved to strike out the exception made of treaties of peace; and Mr. Wilson did not desire twothirds majority in any case. A reconsideration was agreed to. 
Gouverneur Morris recognized the fisheries and the Mississippi as "the two great objects of the Union;" and the legislature would be unwilling to make war on that account, if a majority of the Senate could make peace. Mr. Wilson remarked that if two thirds was required for peace, a minority might perpetuate war; and the old grounds of debate were again traversed. The exception of treaties of peace was finally stricken out by a vote of all the other States against New Jersey, Delaware, and Maryland.

Mr. Wilson and Mr. Dayton then moved to amend, so as to require only a majority of the Senate in all cases of treaties. This failed by nine States against Delaware, with Connecticut divided.

Then Mr. Rutledge and Mr. Gerry moved, in the contrary direction, that for all treaties the consent of two thirds, not of a quorum, but of all the senators, should be required. This was defeated by eight votes to three. $\mathrm{Mr}$. Sherman next moved for a majority of all the senators in such cases. This was defeated, six States against five. Mr. Madison then sought to require two thirds for a quorum. This was defeated by a vote of six to five. Messrs. Williamson and Gerry then moved that no treaty should be concluded without previous notice to all the senators, and giving reasonable time 
I56 EVOLUTION OF THE CONSTITUTION

for their attendance. Only Georgia, North Carolina, and South Carolina supported this.

Then the vote was finally taken on the treaty power as it now stands in the Constitution, and it was accepted by all the States except Pennsylvania, New Jersey, and Georgia.

It would appear from the course of the debate, and from the votes, that the mind of the Convention was never wholly clear respecting the case of conflict between legislative acts and treaties. They evidently regarded a treaty, approved by two thirds of the Senate and the executive, as a supreme law, equal in force to any legislative act, and everywhere obligatory. It is probable that they considered a subsequent act of Congress contravening its provisions, or refusing, or failing to provide means to execute it as a violation of it, to be adjusted as other violations of treaties must be adjusted. Doubtless they considered it unlikely that the executive and Senate who had made the treaty could consent to such a violative act; but the other House might refuse legislation to execute the treaty. Certainly they made no distinction between treaties, whether of peace, of alliance, of commerce, or for any other object of international negotiation. Whatever the treaty, when duly ratified it became the law of the land. There always remained as a security for the treaty-making power the right to make 
the treaty conditional on the approval of the whole legislative authority. Otherwise, the treaty being unconditional, a failure to execute it involved its breach, and justified a demand by the other contracting nation for redress upon peril of war, or other retaliation.

Washington, in refusing the call of the House of Representatives for the executive instructions touching the Jay Treaty, denied the right of the House of Representatives under the Constitution to participate in the making of treaties, in all cases without exception. In his Message of March 30, I796, he says :

"Having been a member of the General Convention and knowing the principles on which the Constitution was formed, I have ever entertained but one opinion on this subject; and from the first establishment of the government to this moment my conduct has exemplified that opinion - that the power of making treaties is exclusively vested in the President, by and with the advice and consent of the Senate, provided two thirds of the senators present concur; and that every treaty so made and promulgated thenceforward became the law of the land. It is thus that the treatymaking power has been understood by foreign nations, and in all the treaties made with them we have declared and they have believed that, 
when ratified by the President, with the advice and consent of the Senate, they became obligatory. In this construction of the Constitution every House of Representatives has heretofore acquiesced; and until the present time not a doubt or suspicion has appeared, to my knowledge, that this construction was not a true one. Nay, they have more than acquiesced; for till now, without controverting the obligation of such treaties, they have made all the requisite provisions for carrying them into effect.

"There is also reason to believe that this construction agrees with the opinions entertained by the state conventions when they were deliberating on the Constitution, especially by those who objected to it because there was not required in commercial treaties the consent of two thirds of the whole number of the members of the Senate instead of two thirds of the senators present, and because in treaties respecting territorial and certain other rights and claims the concurrence of three fourths of the whole number of the members of both Houses, respectively, was not made necessary."

"If other proofs than these and the plain letter of the Constitution itself be necessary to ascertain the point under consideration, they may be found in the journals of the General Convention, which I have deposited in the 
office of the Department of State. In those journals it will appear that a proposition was made 'that no treaty should be binding on the United States which was not ratified by a law,' and that the proposition was explicitly rejected."

After more than one hundred years of experience in the formation of treaties with all nations, and relative to all the subjects of international negotiation, the extent of the power granted continues in the field of congressional debate; particularly in its relation to commercial treaties involving modifications of the tariff. The power to make treaties is given without any limitation, and covers every subject of negotiation between nations. The power to regulate commerce and impose revenue duties was given to Congress in equally un. limited terms, except the condition that they should be uniform for all the States. We have seen that the attention of the Convention was repeatedly called to a possible conflict in the exercise of the powers. Still the Convention adhered to the duplicate provisions, apparently impressed by the necessity that Congress should have power over the general system, and that the treaty-making power should have the right to make exceptional provisions adapted to the ever varying conditions of intercourse with dif. ferent foreign nations. 
The only reasonable interpretation of the conflicting clauses of the Constitution has since been adopted by the Supreme Court of the United States, and should be regarded as now settled upon the highest authority. After several decisions which discussed different phases of the question, that eminent and final tribunal gave its decision upon the effect of both clauses in the following emphatic language :-

"The effect of treaties and acts of Congress, when in conflict, is not settled by the Constitution. But the question is not involved in any doubt as to its proper solution. A treaty may supersede a prior act of Congress, and an act of Congress may supersede a prior treaty." $x$

The method by which "the advice and consent of the Senate" has been invited, or given, has varied greatly during the lapse of the first century of the Constitution. In the early years when that body was small in numbers, Washington, accompanied by the Cabinet member in charge of the subject, personally visited the Senate to consult them, but he soon found that method unsatisfactory, and even personally disagreeable, and abandoned it. $\mathrm{He}$ and following presidents substituted a written mes-

1 II Wall. 62I ; Story's Commentaries on the Constitution, sec. I 508. See also Cooley's Commentaries. 
sage of inquiry addressed to the Senate, and the response was by a resolution of that body in answer to his inquiry. This was sometimes done before the negotiation of the treaty; and sometimes the nomination of a diplomatic minister was accompanied with a statement of the object of his appointment. During Madison's administration the President declined to receive a Committee of the Senate in consultation on the subject, declaring that a committee could with propriety only consult the department in charge. The Senate itself was constitutionally the only body for consultation by and advice to the President in making treaties. The later presidents at times consulted the Senate by a message of inquiry in advance of making the treaty. But gradually they adopted in the majority of cases the habit of completing the negotiation of a treaty in advance of its submission to the Senate, and presenting it as a completed document for their ratification or rejection. The Senate in its turn would ratify or reject the treaty, or consent to it with an amendment which they proposed, leaving to the President his constitutional discretion to approve the amendment and continue the negotiations for its adoption, or to reject it, and allow the negotiations to fail. The final ratification is with the President, after the consent of the Senate has been obtained. 
THE LEGISLATIVE RIGHT TO ORIGINATE MONEY BILLS.

In the scheme of government, as originally approved in the committee of the whole, equal power to originate legislation was given to the two Houses of Congress by unanimous consent. While the Virginia resolutions were under consideration on the last day in the committee of the whole, Mr. Gerry moved to insert, " except money bills, which shall originate in the first branch of the national legislature." Mr. Butler saw no reason for it: "We were always following the British constitution, when the reason of it did not apply. There was no analogy between the House of Lords and the body now proposed to be established." Mr. Madison said, "The Senate would be the representation of the people, as well as the first branch." Mr. Sherman observed, "We establish two branches in order to get more wisdom, which is particularly needed in the finance business. The Senate bear their share of the taxes, and are also the representatives of the people." General Pinckney said, "This distinction prevails in South Carolina, and has been a source of pernicious disputes between the two branches." The motion was then defeated by all the States except New York, Delaware, and Virginia, 
and both Houses retained equal rights in all legislation.

When the long and exasperating debate occurred upon equality of state representation in the two Houses, it was urged on the part of the great States that questions of revenue ought to be determined by a proportional representation. Otherwise, a minority of population, represented by a majority of States, might, contrary to all correct principles, impose burdens on the majority of both wealth and population. This palpable injustice led to an offer on the side of the small States that " all bills for raising or appropriating money, and for fixing the salaries of the officers of the government of the United States, shall originate in the first branch of the legislature, and shall not be altered or amended by the second branch; and that no money shall be drawn from the public treasury but in pursuance of appropriations to be originated in the first branch." This offer was conditioned upon the acceptance of an equal vote in the Senate. A committee, of which Mr. Gerry was chairman, so reported the plan on July 5 .

Mr. Madison regarded this as no valuable concession to the great States. "Experience proved that it had no effect. If some States in the upper branch wished a bill to be originated, they surely might find some member 
from the same States in the lower branch who would originate it." As for amendments, they " could be handed privately by the Senate to members of the other House. Bills could be negatived, that they might be sent up in the desired shape." Gouverneur Morris and others warmly opposed the plan. Mr. Wilson shrewdly remarked, "If both branches were to say yes or no, it was of little consequence which should say yes or no first, which last." It would be better to reverse the order, for " it was a maxim that the least numerous body was the fittest for deliberation, - the most numerous for decision." The question was taken on this clause; and for it voted Connecticut, New Jersey, Delaware, Maryland, and North Carolina (5). Against it were Pennsylvania, Virginia, South Carolina (3), with Massachusetts, New York, and Georgia divided. Although only five States out of eleven voted for it, under their rules it stood as affirmed. But it was well understood that it was still an open question.

On the 16th of July, after references of the compromise to special committees and much debate, the question was taken on the compromise as a whole, including the equal vote in the Senate, the proportional vote in the House, and the clause in question; and it was carried by the same five States in the affirmative against the same three States and Georgia in 
the negative, with Massachusetts divided and New York absent. In this form it went to the Committee of Detail, but still unsupported by a majority of the States.

Again, upon the report of this committee, it came into debate, and Mr. Pinckney moved to strike out the clause, and was supported by Gouverneur Morris, Mr. Wilson, and Mr. Madison. Mr. Mason, Mr. Butler, and Mr. Ellsworth thought it had better stand as a compromise. $\mathrm{Mr}$. Gorham was in favor of originating the bills in the House, but giving power to the Senate to amend. The clause was struck out by the votes of New Jersey, Pennsylvania, Delaware, Maryland, Virginia, South Carolina, and Georgia (7), against New Hampshire, Massachusetts, Connecticut, and North Carolina (4), without disturbing the equality of States in the Senate. But Mr. Randolph gave notice of a motion to reconsider, and Mr. Mason, with some others, still regarded it as necessary to adhere to the compromise, although the large States had disclaimed its supposed value and the small States were willing to adhere if the large States desired it.

Upon the reconsideration, Mr. Randolph proposed to limit the exclusive power to "bills for the purpose of revenue," to obviate objection to the words " raising money," which might happen incidentally, not allowing the 
Senate by amendment to either increase or diminish the same. His motion was in the following words: "Bills for raising money for the purpose of revenue, or for appropriating the same, shall originate in the House of Representatives; and shall not be so amended or altered by the Senate as to increase or diminish the sum to be raised, or change the mode of levying it, or the object of its appropriation."

Mr. Mason renewed his arguments in its favor. Mr. Wilson again opposed it with warmth. He said "it would be a source of perpetual contentions when there was no mediator to decide them. The President here could not, like the executive in England, interpose by a prorogation or dissolution. This restriction had been found pregnant with altercation in the eight States where the constitutions had established it. The House of Representatives will insert other things in money bills, and, by making them conditions of each other, destroy the deliberate liberty of the Senate." And he recited a remarkable case of this misuse of power by the House of Commons. Gouverneur Morris thought its proposed advantages illusory, because the "Senate could tire out the other House and extort their concurrence in favorite measures as well by their negative or withholding their assent as by adhering to a bill introduced by themselves. In respect to 
the representatives ' holding the purse-strings,' both Houses must concur in the untying; and of what importance could it be which untied first, which last?" Mr. Madison made a full argument on the same side. Mr. Read would follow the example of many of the States, retaining the exclusive authority in the first House, but giving the Senate liberty to amend. Mr. Carroll said the clause in the Maryland constitution was "a source of continual diffculty and squabble between the two Houses."

At the end of this searching debate (August I 3 ) three votes were taken. First, on the exclusive right in the first House to originate money bills: the ayes were New Hampshire, Massachusetts, Virginia, North Carolina (4); the noes were Connecticut, New Jersey, Pennsylvania, Delaware, Maryland, South Carolina, Georgia (7). Second, on originating by the first House and amending by the Senate: the vote was the same, - noes seven, ayes four. Third, on the question of no appropriations of money except those originating in the first House: Massachusetts alone voted aye (I), the other ten States voting no.

Here, for the first time, appears a very strong conviction of the Convention that a distinction should be made between bills for raising revenue and bills for appropriating money.

Two days later Mr. Strong, of Massachu 
setts, moved to insert in another place the same clause of Mr. Randolph which had been voted down on the $3^{\text {th. It }}$ It was thought best to postpone the question for the time and consider other matters, which was done. Subsequently a committee of eleven was appointed to consider various old and new questions of detail in the Constitution as reported, and on the $5^{\text {th }}$ of September Mr. Brearley reported from this committee, among other clauses, the following: "All bills for raising revenue shall originate in the House of Representatives, and shall be subject to alterations and amendments by the Senate; no money shall be drawn from the treasury but in consequence of appropriations made by law."

Again it was postponed on motion of Gouverneur Morris, who said it had been " agreed in the committee on the ground of compromise," and he wished to await the disposition of other clauses. Though opposed, this motion was carried by nine States against two. On the 8th of September the long dispute was ended. After a verbal amendment, which was made unanimously, the clause was adopted as it now appears in the Constitution, except that the Committee on Style, in their revision, transposed the last clause to another place. The final vote shows its acceptance by all the States except Delaware and Maryland. 
Among the published objections of George Mason, on account of which he refused to sign the Constitution, was this, that "the Senate have the power of altering all money bills and of originating appropriations of money."

It thus appears that by express votes the Convention refused to extend the exclusive power of the House beyond bills for raising revenue, and by express vote decided to leave in the Senate an equal power to originate bills making appropriations of public money, and that only a minority of the Convention attached constitutional importance to the former provision.

\section{ADMISSION OF NEW STATES.}

It was among the clauses of the Virginia plan that provision should be made for the admission of new States into the Union, whether with a voluntary junction of government and territory, or otherwise, and without requiring the consent of all the States. This was agreed to in the committee of the whole. It was remembered that there had been discussion of new States to be formed in the west of North Carolina, west of Pennsylvania, in Maine, in Vermont, and in the Western region. In the Convention itself there had been talk (June I8) of a readjustment of territory among the States with a view to equalize them.

When the Committee of Detail made their 
report, this clause, modified in form, provided for the admission of " new States lawfully constituted or established within the limits of the United States;" but requiring the consent of two thirds of each House of Congress. If formed within the limits of an existing State, the consent of its legislature was required. They were to come in on equal terms with old States, but might be subjected to conditions concerning the public debt then existing.

Gouverneur Morris objected to this equality, with only the condition respecting the public debt. He did not wish to bind the legislature to admit Western States on such terms. Mr. Madison, Mr. Mason, and Mr. Sherman thought it wise to make them equals and not degrade them. The best policy was to treat them as friends, not enemies. Mr. Morris admitted it was impossible to discourage the growth of the West; but he did not wish to throw the power into their hands. Mr. Langdon and Dr. Williamson would have the legislature free to act according to circumstances. Mr. Morris's motion prevailed, and that part of the clause was struck out.

Mr. Morris then moved to make the article read, "New States may be admitted by the legislature into the Union; but no new States shall be erected within the limits of any of the present States, without the consent of the 
legislature of such State, as well as of the general legislature." The first clause was accepted unanimously; the latter clause by a vote of six States to five. There arose a debate upon the point of requiring the assent of the old States before a new State, formed out of their distant lands, and with separate interests, could be admitted; and on the question of admitting Vermont, which had received pledges, independent of the consent of New York. Mr. Dickinson held it improper to require the small States to secure the large ones in their extensive claims of territory. Mr. Carroll wanted to maintain the claim of the United States to the "back-lands." "Were the States to be cut up without their consent?" suggested Mr. Rutledge. Various amendments and provisos were offered to meet objections, and voted on, and the subject was clouded by serious differences of opinion. Mr. Morris proposed a substitute which passed, eight States to three, which met the case of Vermont and other possible cases, by employing the word jurisdiction, instead of territory; and there was added, also on his motion, a clause giving Congress power to dispose of and make all needful rules and regulations respecting its territory and property, substantially as now found in Article IV, Section 3, of the Constitution. 
Mr. Morris had indulged prejudices and fears respecting "that range of new States which would soon be formed in the West," and wanted "a rule of representation so fixed as to secure to the Atlantic States a prevalence in the national councils." Their interests would be different; they would know less of the public interest; and, "in particular, will be little scrupulous of involving the community in wars, the burdens and operations of which would fall chiefly on the maritime States." There ought, therefore, to be provisions "to prevent the maritime States from being hereafter outvoted by them." Mr. Gorham had expressed similar opinions in favor of "dealing out the right of representation in safe proportions to the Western States."

Mr. Gerry also would turn attention "to the dangers apprehended from the Western States." $\mathrm{He}$ would admit them on liberal terms, but not put himself in their hands. They would oppress commerce and drain wealth into the Western country. He would limit the number to be admitted, so that they could never outnumber the Atlantic States. He proposed to limit the number of representatives in the first branch from the new States, so that they should never exceed the number from the old States which should accept the Constitution, and Mr. King seconded him. Mr. Sherman thought 
" there was no probability that the number of new States would ever exceed that of the exist. ing States. Besides, we are providing for our children and our grandchildren, who would be as likely to be citizens of new Western States as of the old States. On this consideration alone we ought to make no such discrimination as that proposed." Mr. Gerry admitted there was "a rage for emigration from the Eastern States to the Western country, but he did not wish those remaining behind to be at the mercy of the emigrants." His motion was wisely defeated by five votes against four, with Pennsylvania divided.

The power was impliedly left in Congress to impose conditions on the admission of new States not involving their equal representation; but it has never been harshly used, and only applied to the public lands and Union property, for which they, in turn, have been well compensated out of the public land. The injustice now is more often seen in refusal of admission when solicited and merited. They have nullified all the original fears entertained by the Atlantic States and have vastly strengthened the Union.

NATIONAL CONTROL OVER STATES.

In the Virginia plan, as submitted by Governor Randolph, appeared the following pro- 
vision: that the national legislature ought to be empowered " to negative all laws passed by the several States contravening, in the opinion of the national legislature, the Articles of Union, or any treaty subsisting under the authority of the Union; and to call forth the force of the Union against any member of the Union failing to fulfil its duty under the Articles thereof."

This proposition seemed to be the corollary of the other which immediately preceded it: " that the national legislature ought to be empowered . . . to legislate in all cases to which the separate States are incompetent, or in which the harmony of the United States may be interrupted by the exercise of individual legislation." Neither Mr. Pinckney nor Mr. Rutledge, nor Mr. Randolph himself nor Mr. Madison, liked the vagueness of the term "incompetent." They all wished it might be possible to enumerate the powers. Nevertheless, the phrase was adopted by a vote of all the States except Connecticut, which was divided.

On the right to negative state laws, it passed without even a dissent, upon its first consideration.

Upon the right to use the force of the Union against delinquent States, Mr. Madison doubted its practicability and justice "when applied to people collectively and not individu- 
ally." He hoped to find a system which would render this resource unnecessary; and moved a postponement, which was agreed to.

The right to negative state laws came up again a few days later, when Mr. Pinckney moved to make the clause read, "That the national legislature shall have authority to negative all laws which they should judge to be improper." He said that "the States must be kept in due subordination to the nation; that this universal negative was in fact the corner-stone of an efficient national government." Mr. Madison agreed with him. Mr. Gerry had "no objection to authorize a negative of paper money and similar measures," but did not want the power to go too far. Mr. Sherman wanted the negative to be defined. Mr. Wilson made a cogent argument for the clause, reminding the Convention of the brotherly self-abnegation of States in the beginning of the Revolution, when they would say, "We are now one nation of brethren, - we must bury all local interests and distinctions. The tables at length began to turn, jealousy and ambition to display themselves. Each endeavored to cut a slice from the common loaf, till at length the Confederation became frittered down to the impotent condition in which it now stands. It is the business of this Convention to correct its vices, especially the want of an effectual control in 
the whole over its parts." Mr. Bedford, Mr. Butler, and Dr. Williamson opposed the motion. It was defeated, seven States to three, and Delaware divided.

It was discussed in Convention July 17 , when Gouverneur Morris thought the power would be terrible to the States, and that it would be unnecessary if sufficient powers were conferred on the general government. Mr. Sherman also believed it unnecessary, as the courts in the States would hold invalid any law contravening the authority of the Union. Mr. Martin also opposed it, but Mr. Madison still maintained its necessity for the preservation of harmony in the Union, and was supported by Mr. Pinckney. The clause was then defeated by all the States against only Massachusetts, Virginia, and North Carolina; and a substitute was unanimously adopted, declaring the laws of the Union made in pursuance of its articles, and the treaties, "to be the supreme law of the respective States," and binding upon their judiciary.

On the $23 \mathrm{~d}$ of August Mr. Pinckney renewed the effort to establish a negative on state laws, and was supported by Mr. Broom, of Delaware, Mr. Madison, Mr. Wilson, and Mr. Langdon. It was opposed by Messrs. Sherman, Ellsworth, Mason, Gouverneur Morris, and Rutledge. The latter said, "Will any 
State ever agree to be bound hand and foot in this manner? If nothing else, this alone would damn, and ought to damn, the Constitution." After an adverse vote, six States against five, Mr. Pinckney withdrew the proposition, and the effort to establish this right in Congress was abandoned. The controlling reasons for this change of opinion appear to have been, first, its offensiveness to the States; second, the difficulty in execution, whether all laws must be sent up for approval or suspended awaiting Federal decision, or other manner of its exercise; third, and chiefly, that it was unnecessary, as the courts were bound to obey the declared and admitted supremacy of national Constitution, laws, and treaties.

The other clause, authorizing force against delinquent States, disappeared under the strong objections to it as practically suggesting internecine war. Having adopted the plan of a government acting directly on the people and ignoring in national affairs the separate state jurisdictions, except as geographical divisions, force was only needed for individuals, and would be thus applied to all the components of a State, whose corporate action could give no rights or justification of wrongs against the supreme authority of the Union. The whole system of quotas and requisitions upon States being abandoned, the necessity to punish state delin- 
quency no longer existed. For the United States, become independent of and supreme over state action for Federal purposes, there remained for punishment only the individuals offending. To this end the foregoing provision was moderated into one giving Congress authority "to provide for calling forth the militia to execute the laws of the Union, suppress insurrections, and repel invasions."

Thus was carried out the original and gradually developed scheme of a supreme government which went, both for its authority and for its effects, behind state constitutions and laws, and in its operations recognized only one people in the whole land subject to its jurisdiction. If a corporate State even organized an insurrection against the United States, the force of the Union was to be applied to all the individuals entering into it, whether state offcers and holding state commissions or simple volunteers. All would be equally liable to punishment as offending citizens of the United States violating their supreme allegiance.

THE GUARANTEE OF A REPUBLICAN FORM OF GOVERNMENT TO THE STATES, AND THEIR PROTECTION.

The eleventh resolution of the Virginia scheme contained the proposition that the national government should guarantee to each 
State its territory and a republican form of government. The guarantee of territory, as already recited, was rejected on account of the uncertainty of its extent and the conflicting claims of States and of the United States. In the discussion upon it, Mr. Read added the reason that the proposal "abetted the idea of distinct States, which would be a perpetual source of discord. The only cure for this evil was in doing away States altogether, and uniting them all in one great society."

The clause was first passed in committee with an amendment so as to guarantee "a republican constitution and its existing laws" to each State. When it came up for discussion Gouverneur Morris assailed the guarantee of laws. He would not have "such laws as exist in Rhode Island guaranteed." It was explained that the object was "merely to secure the States against dangerous commotions, insurrections, and rebellions." Mr. Mason thought that without this right "the general government must remain a passive spectator of its own subversion," as rebellions against the United States would originate in the individual States. Mr. Houstoun did not want existing state constitutions guaranteed; some of them, like that of Georgia, were bad.

Mr. Gorham "thought it strange that a rebellion should be known to exist in the empire, 
and the general government have no power to subdue it. An enterprising citizen might erect the standard of monarchy in a State, gather partisans from all quarters, extend his views from State to State, and threaten to establish a tyranny over the whole, and the general gov. ernment remain an inactive witness of its own destruction." A war of words might be allowed to go on, but upon appeal to the sword the general government must interpose, however difficult it may be. Mr. Carroll thought such an authority ought to be desired by every State. It was doubtful if the existing Confederacy had such a power. After some further debate, Mr. Wilson moved as a substitute that "a republican form of government shall be guaranteed to each State, and that each State shall be protected against foreign and domestic violence." This was accepted on all sides and adopted unanimously, and in that form it went to the Committee of Detail.

It was reported by them with the last clause amended, so as to confine the absolute guarantee to cases of "foreign invasion," and requiring the application of the state legislature before intervening " against domestic violence."

When this report was taken up the word "foreign" was struck out as superfluous, "invasion" implying it. Mr. Dickinson moved to strike out "on application of its legislature." 
He thought it essential to the general tranquillity that the United States should in all cases suppress domestic violence; for it might proceed even from the legislature itself, or from disputes between the two branches. Mr. Dayton cited the case of Rhode Island as showing the necessity for giving ample power to the United States. But on vote this prior application was retained, eight States to three. It was moved to substitute "insurrections" for "domestic violence," but that failed, six votes to five. On motion of Mr. Dickinson, the words "or executive" were inserted after "legislature," so that action might be taken on his application, without waiting for the legislature. This was carried, eight States to two, with Maryland divided. Mr. Martin would confine the application of the executive to the recess of the legislature. But only his own State supported him. As thus amended the guarantee clause was passed by nine States against two. It was afterwards modified by inserting after the word "executive" the parenthetical clause, "when the legislature cannot be convened."

But, in order to understand the purposes of the Convention in thus limiting the guarantee against domestic violence to cases of a demand for protection made by either the legislature or the governor of a State, attention must be 
given to the two other powers vested in Congress by the Committee of Detail in the same report: "to subdue a rebellion in any State, on the application of its legislature;" and "to call forth the aid of the militia, in order to execute the laws of the Union, enforce treaties, suppress insurrections, and repel invasions."

Of these two provisions the latter subsequently assumed the form in which the power was given to Congress: "to provide for calling forth the militia to execute the laws of the Union, suppress insurrections, and repel invasions," and was thus unanimously adopted.

When the other power, "to subdue rebellion," was under discussion, Mr. Pinckney and Mr. Morris moved to strike out " on the application of its legislature." Mr. Martin opposed it, saying, "The consent of the State ought to precede the introduction of any extraneous force whatever." It was proposed to extend the application to the governor. Gouverneur Morris said, "The executive may possibly be at the head of the rebellion. The general government should enforce obedience in all cases where it may be necessary." Mr. Gerry was against "letting loose the myrmidons of the United States on a State, without its own consent." Mr. Langdon believed that the apprehension of the United States force would have a useful effect in preventing insurrec- 
tions. Gouverneur Morris remarked, "We are acting a very strange part. We first form a strong man to protect us, and at the same time wish to tie his hands behind him. The general legislature may surely be trusted with such a power to preserve the public tranquillity."

It was then agreed that the United States might act without the state legislature when it could not meet, by five States to three, with two divided. On motion it was further amended by defining the "rebellion" to be a rebellion against the State. "There might be a rebellion against the United States," said Mr. Dickinson and Mr. Madison. This provision had no relation to such a case. The whole clause as amended was then rejected, being sustained by four votes against four, and two absent.

Upon recurrence to the question, presented in connection with the clause guaranteeing a republican form of government to each State, the unconditional protection of the United States was guaranteed only against invasion; and conditional protection against "domestic violence," if required by the legislature, or by the governor when the legislature cannot be convened.

It is evident that this last protection was intended exclusively for the cases where the violence was directed against the state action 
or authority, and by its own citizens; and therefore the necessity for national intervention was to be determined by that state authority which was offended and assailed. If the violence was offered by another State, or a foreign country, it became "invasion," and not "domestic violence;" and then the guarantee of the protection of the United States became as absolute as was the guarantee of a republican form of government.

For the rest, for the case of illegal or violent offences, insurrections, and invasions, directed against the Union, the United States was its own absolute judge as to the action required, and was empowered to call to its aid the militia of all the States. Power to this end was inherent, also, under the general powers to provide for the common defence, and to pass all necessary laws to give effect to the Constitution, which with its laws covered all the territory of the Union. The national life and authority given by the Constitution could be defended by all the three departments which it established for that express purpose, - the legislative, the executive, and the judicial; and the means were left to its own discretion. The fourth section of Article IV was designed to enforce and regulate its duty towards a State of the Union only, and for the benefit of the State exclusively. 
MODE OF RATIFICATION OF THE CONSTITUTION.

When the subject of providing state conventions for the ratification of the new Constitution was before the Convention, as found in the Virginia plan, Mr. Sherman thought popular ratification unnecessary, and that ratification by Congress and the state legislatures would be sufficient.

Mr. Madison, on the contrary, held it essential. He added, with singular foresight, "As far as the Articles of Union were to be considered as a treaty only of a particular sort among the governments of independent States, the doctrine might be set up that a breach of any one article by any of the parties absolved the other parties from the whole obligation." He therefore wanted the ratification "by the supreme authority of the people themselves."

Mr. Gerry seemed afraid of this mode for the Eastern States, as the people in that quarter had " the wildest ideas of government in the world. They were for abolishing the Senate in Massachusetts and giving all the other powers of government to the other branch of the legislature." Mr. King thought the legislatures likely to be hostile to the new system, as they would lose power by its adoption. Mr. Wilson, with characteristic clearness of perception, desired that provision should be made for 
giving effect to the ratification of less than the whole number of States, so that the government could be established by the States desiring it, leaving the door open to the others to enter. This was remembered in the end, though received in silence at the time, except that Mr. Pinckney hoped that, if not unanimous, nine States might undertake the new system. Upon taking the vote in committee on this question, ratification by the people was sustained by the votes of Massachusetts, Pennsylvania, Virginia, North Carolina, South Carolina, and Georgia (6), against New York, Connecticut, New Jersey (3), with Maryland and Delaware divided.

In the great debate which followed the introduction of the New Jersey plan, Mr. Madison's prime objection to it was that "its ratification was not to be by the people at large. It could not, therefore, render the acts of Congress, in pursuance of their powers, paramount to the acts of the States." It is worthy of note that the tenacity of the adherence of the framers of the Constitution to this point of ratification by the people arose from their determination to take from the corporate States all power, or pretence of power, to nullify or control national legislation by any act of their own legislatures. They had witnessed this nullification in the ruin of the Confederacy. Constitutional 
history can be correctly read only in the light of this fixed resolution of the majority of the Convention. Rufus King, in a critical debate upon the last hope of compromise, said he "considered the proposed government as substantially and formally a general and national government over the people of America. There will never be a case in which it will act as a federal government, - on the States, and not on the individual citizens."

When the provision came up in Convention on the report of the committee of the whole, Mr. Ellsworth, seconded by Mr. Paterson, moved its ratification by the state legislatures. Mr. Mason opposed them, asserting that legislatures were not sovereign, they were creatures of the constitution of the State; and no such power, in some States certainly, was conferred by their constitutions. "Whither, then, must we resort? To the people, with whom all power remains that has not been given up in the constitutions derived from them. It was of great moment that this doctrine should be cherished, as the basis of free government." If referred to the legislatures, "succeeding legislatures, having equal authority, could undo the acts of their predecessors." Mr. Randolph, Mr. Gorham, Dr. Williamson, Mr. King, Mr. Madison, and Gouverneur Morris opposed the motion of Mr. Ellsworth. Mr. Madison especially 
made the point that the difference "between a system founded on the legislatures only and one founded on the people was the true difference between a league or treaty and a constitution." He added that judges might decide for the validity of a law, though unwise and perfidious, which violated a treaty; but a law violating a constitution established by the people themselves would be considered by the judges as null and void. By the law of nations a breach of one article of a treaty releases the other party from all his engagements. Under a constitution, "the nature of the pact has always been understood to exclude such an interpretation." The vote was then taken, and the proposed ratification by the legislatures was rejected by New Hampshire, Massachusetts, Pennsylvania, Virginia, North Carolina, South Carolina, and Georgia (7), against Connecticut, Delaware, and Maryland (3).

Gouverneur Morris then moved there should be one general convention for its consideration, amendment, and establishment; but he found no support in this. And on the question of agreeing to the clause as found in the text, it was carried by all the States against Delaware only. This debate and decision occurred on the $23 \mathrm{~d}$ of July.

On the 3 Ist of August, Gouverneur Morris was induced to move that the choice of mode 
of ratification be left to the States. After a debate, in which his opponents insisted upon this resort to the people, "to first principles," as getting over all difficulties, the motion was defeated by six States against Connecticut, Pennsylvania, Maryland, and Delaware.

The number of States required to ratify it in order to give it force and effect between them was then considered, and it was resolved to take the same number nine, to which they were already accustomed under the Confederacy, as giving final validity to their acts. Maryland alone supported the motion to make the number thirteen; Messrs. Madison, Wilson, and Clymer desired valid ratification by any seven or more States, which should embrace a majority of the people, and of representatives in the first branch of Congress. Mr. Sherman proposed ten States, but this was supported only by four votes. The number nine was accepted by eight votes to three; and the article was then agreed to by all the States except Maryland, whose delegates were embarrassed by a clause in their state constitution.

After long, fundamental, and exhaustive debates, it had been repeatedly decided that this should not be a treaty, a league, or a confederacy between States; and as often decided that it should be a constitution of the people, 
organizing them into one common and general government for general affairs, wholly independent of and superior to state governments. Mr. Wilson as early as June 20 had declared his opinion that, "in spite of every precaution, the general government would be in perpetual danger of encroachments from the state governments." Mr. Madison had followed him with the double statement that " there was less danger of encroachment from the general government than from the state governments; and, further, that the mischief from encroachments would be less fatal if made by the former than if made by the latter. All the examples of other confederacies prove the greater tendencies in such systems to anarchy than to tyranny; to disobedience of the members than usurpations of the federal head. Our own experience had fully illustrated this tendency." "The people would not be less free as members of one great republic than as members of thirteen small ones. A citizen of Delaware was not more free than a citizen of Virginia; nor would either be more free than a citizen of America. Supposing, therefore, a tendency in the general government to absorb the state governments, no fatal consequence could result."

With great difficulty the members of the Convention emerged from their narrower 
views, as citizens of a colonial circumscription, into the greater light and liberty of citizens of a great republic, destined to such historic grandeur that none in presence of it should longer boast of his local attachments, but should rather announce, with Roman pride, that he was an American Citizen.

OATHS BY STATE OFFICERS TO SUPPORT THE CONSTITUTION.

One important provision of the plan introduced by Mr. Randolph was that which " Resolved, that the legislative, executive, and judiciary powers within the several States ought to be bound by oath to support the Articles of Union." It provoked objections upon its first consideration, and was postponed. Upon its recurrence, Mr. Sherman declared against it, as " an intrusion into the state jurisdiction." Mr. Gerry suggested there was as much reason for requiring an oath of fidelity to the States from national officers as vice versa. Luther Martin moved to strike it out. Evidently there still lingered the idea that they were only creating a subordinate - at most another equal - State, and not a superior.

Mr. Randolph sustained it, as necessary to prevent competition between the national and state constitutions and laws. "The national authority needs every support we can give it. 
I92 EVOLUTION OF THE CONSTITUTION

Unless the state executive and judiciary be brought under some tie to the national system, they will always lean too much to the state systems whenever a contest arises between the two."

Connecticut, New Jersey, Delaware, and Maryland (4) voted to strike it out; all the other States (7) sustained the provision. Upon the question of adopting the resolution itself, New York joined the four States in the minority, the vote in its favor standing six to five; and it was favorably reported to the Convention. When it was again reached, Mr. Gerry's opinion was changed. He thought at least " one good effect would be produced by it. Hitherto, the officers of the two governments had considered them as distinct from, and not as parts of, the general system; and had, in all cases of interference, given a preference to the state governments. The proposed oath will cure that error." Progress had been made in the conception of a national government. The resolution was adopted without further dissent.

When the clause was reported from the Committee of Detail, on Mr. Charles Cotesworth Pinckney's motion this addition was made: "but no religious test shall ever be required as a qualification to any office or public trust under the authority of the United States;" 
and "affirmation" was permitted, as an alternative for the oath.

After the report by the Committee of Revision, the clause was adopted in the following form: "The senators and representatives before mentioned, and the members of the several state legislatures, and all executive and judicial officers, both of the United States and of the several States, shall be bound by oath, or affirmation, to support this Constitution; but no religious test shall ever be required as a qualification to any office or public trust under the United States." As if to add to its significance and force, it immediately follows the clause declaring the United States Constitution, laws, and treaties "the supreme law of the land." By this association of all state and national officers in one universal obligation, the entire political organism of every State was brought into submission to the national Constitution and government. It was the sanction of an indissoluble allegiance of the States to the nation, throughout the whole extent of legitimate national jurisdiction.

THE SIgNATURE AND PUBLICATION OF THE CONSTITUTION.

On Saturday, September I5, several last attempts were made to amend the final draft, as reported by the Committee of Revision, in 
respect to several points which had been before seriously debated. It was especially desired to amend the fifth article, relating to future amendments of the Constitution. Among others, it was proposed to add a proviso, "that no State shall, without its consent, be affected in its internal police, or deprived of its equal suffrage in the Senate." This was rejected by all the States except Connecticut, New Jersey, and Delaware. Then the amendment was offered omitting the "internal police" clause, which confined it to the preservation of equal suffrage in the Senate; and this proviso was adopted.

The majority of the delegates of New York had seceded from the Convention in July, Hamilton alone remaining; and he could not alone commit that State by his signature. Washington had fallen into deep despondency over the secession of that leading State, and had written to Hamilton: "I almost despair of seeing a favorable issue to the proceedings of the Convention, and do therefore repent having any agency in the business." But he urged Hamilton to remain in the Convention and to continue his efforts; nor did he himself quite despair. Happily, most of the remaining members of the opposition, although reluctantly, surrendered to the desire for formal unanimity. 
After the adoption of the fifth article, the question was put by the president, Shall the Constitution as amended be adopted? It was a solemn moment; and there were not a few hesitating minds. All the States present, eleven in number, answered in the affirmative. It was then ordered that the Constitution should be engrossed, and the Convention adjourned until Monday.

The intervening Sunday was a day of anxious thought and consultation. It was deemed of great importance that all the delegates present should sign the great act, that it might go to the country with the aspect of unanimity. It was thought best that Dr. Franklin, the venerable and wise moderator of opinions, should make this conciliatory effort.

On the morning of Monday, the 17 th of September, he rose, and, because of his infirmity, asked Mr. Wilson to read the observations he wished to offer. After a temperate and patriotic appeal for unanimity, he proposed a form which simply certified to the fact of record, that it was "done in Convention by the unanimous consent of the States present."

As a further proffer of conciliation, and to remove one objection entertained by several delegates, Mr. Gorham moved to increase the possible number of representatives in the first branch of Congress to one for thirty thousand, 
instead of the ratio of forty thousand inhab. itants, and was supported by Mr. King and Mr. Carroll. But, most powerful influence of all, General Washington, before putting the question, and with a modest apology for offering any remarks, expressed the satisfaction he would experience if it should be adopted. His voice had often been heard in private conversation with members upon the great topics discussed, but never before from the tribune, and now its potency was felt by all. The amendment was accepted unanimously.

The Constitution was then enrolled, in order to be signed. The certificate preceding the signature was adopted by ten States, against South Carolina divided, two delegates of the latter State being inclined to a form which more strongly expressed their consent to the Constitution. Mr. Hamilton, strongly opposed to the instrument as not giving enough power to the national government, but signing it individually as a delegate from New York, was anxious that every member should sign. "Is it possible," said he, "to deliberate between anarchy and convulsion on one side, and the chance of good to be expected from the plan on the other?" But no appeal could convert the opposing sentiments of Randolph, Gerry, and Mason. These three only, of all who were present, refused to put their names to that con- 
secrated roll, which was destined to a glorious immortality of remembrance among their countrymen, and to be the eternal signal of an epoch in the civilization of mankind. Happy were they who sacrificed local prejudice and jealous fears to the welfare of the greatest number; for they secured to themselves a fame for which kings might well exchange their crowns, - a fame which shall endure till the monuments of history perish from the earth.

In submitting the result of their labors to the Congress of the Confederation, to be by them communicated to the several States, the Convention accompanied it with a letter, which briefly recounted the difficulties to be overcome, and their hopes of the approval of their action. They said :-

"It is obviously impracticable, in the Federal government of these States, to secure all rights of independent sovereignty to each, and yet provide for the interest and safety of all. Individuals entering into society must give up a share of liberty to preserve the rest. . . . In all our deliberations on this subject we kept steadily in our view that which appeared to us the greatest interest of every true American, - the consolidation of the Union, - in which is involved our prosperity, felicity, safety, perhaps our national existence."

This letter was approved by the Convention, 
signed by Washington, and with the Constitution transmitted to the Confederate Congress, then in session at New York.

On the 2oth of September these communications were received by that body, and for the first time published to the country. The Constitution was assailed at once on many sides, and for the very reasons which had been so fully canvassed and overcome in the Convention. From the congressional delegates of Virginia and from New York came the bitterest hostility. But Madison soon appeared in his seat, and the friends of the Constitution joined the battle with courage and organization. On the 28 th of September they succeeded in carrying a resolution transmitting the documents to the legislatures of the several States, in order to be submitted to conventions in the manner resolved by the national Convention. The great contest was then transferred to the separate States, where its fate during several anxious months was suspended in a doubtful balance. 


\section{$\mathbf{X}$ \\ THE ACTION OF THE STATES IN RATIFICATION}

THE question came first before each legislature whether they would even call a conven. tion. Second, should it be promptly called or deferred to await the action of other States?

Richard Henry Lee, of Virginia, and his confederates in different States were indefatigable in disseminating hostile views and their plans for the defeat of the Constitution throughout the Confederacy. Against them, most fortunately for the country and the Union, were arrayed its equally indefatigable friends. Hamilton, Madison, and Jay contributed those remarkable and historical commentaries on the proposed Constitution known as "The Federalist," and now preserved as part of the history of the nation. The entire press of the country was engaged on the two sides. The courage and violence of assault on one side were met and resisted by an equal bravery and resolution in defence. Above all leaders on either side rose the great and revered figure of Washington, who, from his retreat at Mount Vernon, expressed his patriotic hopes and 
wishes in numerous communications, which reached and influenced the controlling characters in many States. The cry of the nationalists was, "Union or dissolution, - the Constitution or anarchy." The discussion went on in every corner of the various States, in private conversation as well as in public assemblies. The inimical effort was made in several of the States to declare the ratification conditional upon amendments to be adopted ; but Madison gave the opinion that such action could not be construed as a ratification. It must be unconditional or the State could not be included in the Union. The influence of Monroefortunately, a much weaker character than Madison - was cast against the Constitution. Jefferson, from beyond the seas, proposed a cunning measure of opposition that came near proving fatal to a complete union. He recommended the adoption of the Constitution by nine States in order to bring it into existence, the others standing out until proposed amendments should be adopted. This evil counsel produced bad fruits, but they fortunately failed to ripen into the threatened results.

Delaware, least of the sisterhood, was first to decide. With joy and with unanimity her voice was given for ratification on December 7, 1787 .

Pennsylvania was but little later. Her con- 
vention was earlier in session, but, thwarted by a resolute minority, the debate was prolonged and her action delayed. On the I Ith of December, Wilson, still the strong champion of the new Union, declared, "This system is not a compact; I cannot discern the least trace of a compact; the introduction to the work is not an unmeaning flourish. The system itself tells you what it is, - an ordinance, an establishment of the people." By a vote of forty-six to twenty-three Pennsylvania ratified the Constitution on the 12th of December, 1787 .

New Jersey next, and only later by a day, gave her ratification to the Constitution "and every part thereof," with unanimity of voices, on December I 3,1787 .

Georgia began the new year with her unanimous assent, given on the $2 \mathrm{~d}$ of January, 1788 .

Next came Connecticut, whose statesmen had done so much to build the new edifice, and whose judge, the learned Johnson, had presided over its final grace of form. By a vote of one hundred and twenty-eight to forty this State gave her adherence to the new plan of government on January 9, I 788 .

Friends and enemies alike now fixed their eyes on Massachusetts, the State next to Virginia the most important of those whose 
action was awaited. Her delegate, Elbridge Gerry, had refused to sign, and had made public his reasons therefor. He was defeated for the state convention by his townsmen. But elsewhere strong opponents of the new government were elected, and a count showed its friends to be in a minority. By wisdom in action, by reason in debate, and chiefly by personal influence and solicitation, enough votes were won over in the end to secure an approval of the Constitution by a vote of one hundred and eighty-seven to one hundred and sixtyeight. Massachusetts, after a hard, long, and doubtful struggle, thus brightened the hopes of patriotic Virginians on February 6, 1788.

Maryland lay too near Virginia to escape the infection of the hostility developed in that State by Richard Henry Lee, Patrick Henry, and other dissidents. But on the great question her people were sound in most of the counties. The number elected of enemies of the new Union was not large, but their opposition was very bitter. Her convention gave its approval, by a vote of sixty-three to eleven, on the 26th of April, I 788.

In South Carolina the seeds of Virginia discontent, and of a possible Southern confederacy, had been widely sown. The fruit was a persistent opposition offered by several leaders of public opinion. After ten days of contest 
for defeat or postponement of the ratification, the friends of the Constitution carried the day, by a vote of one hundred and forty-nine to seventy-three, on the $23 \mathrm{~d}$ of May, 1788 .

One State more, and the new government could be inaugurated! New Hampshire had modestly awaited the action of larger States. Now the ambition of her unionists was to signalize their State by completing the sanction of the Constitution. This was done while the debate was still prolonged in the Virginia Convention; and New Hampshire became the ninth State, by a vote of fifty-seven to forty-six, on June $21,1788$.

In Virginia there was a contest of the greatest obstinacy, with few, if any neutrals. Henry, Grayson, and Mason led the hostile forces. Madison, Pendleton, Marshall, and Randolph (now reconciled) confronted them at every point in defence of the Constitution. Patrick Henry sounded the trumpet of state sovereignty with the cry, "The Constitution is the severance of the Confederacy. Its language, 'we, the people,' is the institution of one great consolidated national government of the people of all the States, instead of a government by compact with the States for its agents." Pendleton rallied the unionists to the cry, "Who but the people can delegate powers, or have a right to form government? There is no quarrel 
between government and liberty: the former is the shield and protector of the latter. The question must be between this government and the Confederation, which is no government at all. This is to be a government of laws, and not of men." From the second day of June the war was raged at Richmond with alternate hopes and fears. Finally, having by her delay yielded to New Hampshire the honor of that conclusive sanction which the ninth State could give to the new Union which she herself initiated, Virginia, by a vote of eighty-nine to seventy-nine, ratified it, being the tenth State, on June 25 , I 788 .

The friends of the Constitution awaited the action of the remaining States with less anxiety, now that the three outstanding States were wholly separated from each other, and whether single or confederated would be powerless against the Union. The convention of New York met while that of Virginia was still in the throes of the great debate. There had been a certain concert of action, through Richard Henry Lee and Governor Clinton, of the enemies of the Union in the two States. Clintor organized and led them in the convention of New York, and was chosen its president, and had the aid of the two seceders, Yates and Lansing. The friends of the Constitution had the benefit of the great ability of Hamilton, Jay, 
and Chancellor Livingston. On the eighth day of their session the news arrived that New Hampshire had given the requisite vitality to the Constitution. Nine days later came the report that Virginia had joined the Union. The courage of the anti-unionists, who formed the majority, was broken. They sought a dignified retreat, as in Virginia and Massachusetts, through propositions of future amendment. One of them even proposed to ratify, reserving the right to secede if the amendments should fail. Against this Hamilton spoke with such force that the mover himself abandoned it. But Lansing in substance renewed it. Then Hamilton read the opinion of Madison, just received, that such a condition would vitiate the ratification, affirming that "the Constitution requires an adoption in toto, and forever," thus early crushing the theory of secession. Then the conditional propositions came to an end, and a legal form of ratification was agreed to (there being some absentees), by a vote of thirty to twenty-seven, on July 26 , I 788.

There remained North Carolina, which had in August, I778, refused to ratify prior to amendment. She gave up her opposition to the Constitution only after the organization of the new government, dating its ratification from the 2 ist of November, I 789 . Rhode Island lingered without until May 29, I 790. 
206 EVOLUTION OF THE CONSTITUTION

At last the sun was risen in the heavens, the clouds were dissipated, and all the planets were moving in their respective orbits, their centrifugal impulses balanced by the attractive bonds of the powerful central luminary, which shed upon them light and warmth and force. 


\section{$\mathrm{XI}$ \\ SEQUEL OF AMENDMENTS}

Time was required for both States and people to adjust their opinions and their affairs to the new institutions of government. The majority in some of the conventions had not been fully convinced either as to the extent of the powers surrendered by the States and acquired by Congress and the Judiciary or of the security of each State and its citizens in the exercise of rights not conceded to the Union. Sources of revenue hitherto enjoyed by the States were to be given up, and new sources must be found. What new laws would be passed by this new legislature in which the citizens of each State had so small a share of authority? How should they grow to recognize other States as their sisters and their citizens as brothers? How soon would selfishness give way to equality and fraternity? Would the habit of affection for one's own State ever permit the growth of a superior affection for the union of all the States? Which of the two forces, centrifugal or centripetal, was destined to predominate in the future? The azure sky of patriotic hope was not without its auguries of fear. 
The action of the conventions of such im. portant States as Massachusetts, Virginia, and New York in recommending certain amendments to the new Constitution, which had also the concurrence of other States, rendered their early consideration desirable in the interest of harmony and contentment among the people, now directly charged with the national government.

The first national Congress, therefore, proposed to the several States twelve amendments to the Constitution, covering the points appearing to be most reasonably insisted upon by the States. The first of these proposed to control in a different manner the number of representatives in the first branch of Congress. The second proposed that no law varying the compensation of senators and representatives should have effect until after a succeeding election. Neither of these was ratified by a sufficient number of States to give it validity.

The remaining amendments, being now the first ten articles of amendment appended to the Constitution, and held to be limitations upon possible claims of power by the national government, were ratified by ten States. No returns were made by the States of Massachusetts, Connecticut, or Georgia of their action on them.

The eleventh article of amendment was pro- 
posed at the first session of the Third Congress (1793), in order to surely exempt States from liability to suits in the United States courts brought by citizens of any other State, or by foreigners. The returns of state action upon this subject were so dilatory that Congress passed a resolution in March, I 797, requesting the President to communicate with the eight outstanding States on the subject. From the message of President Adams (January, 1798) it appears that twelve of the sixteen States had at that time certified their ratification, which established the validity of the amendment. New Jersey and Pennsylvania refused their ratification, while South Carolina and Tennessee had not acted upon it.

The twelfth amendment, establishing the present mode of electing the President and Vice-President, was proposed at the first session of the Eighth Congress (1803), and was declared adopted in September, I 804 , by the votes of thirteen out of seventeen States, being three fourths thereof.

The thirteenth, fourteenth, and fifteenth amendments had their origin in questions arising from the late war of secession. The thirteenth had for its object the perpetual abolition of slavery. The fourteenth established the equality of citizenship in all the States, and prohibited every State from abridging the privi- 
leges of citizens of the United States, and from denying to them the equal protection of the laws, and from taking life, liberty, or property without due process of law. It also provided for a reduction of representation in Congress proportioned to the unjust exclusion of any class of citizens from the right of voting; and excluded from holding office under the United States, or any State, certain classes of men who had been en. gaged in the Rebellion, unless first relieved of disability by a vote of two thirds of each branch of Congress. It further provided a constitutional guarantee of the validity of the public debt of the United States, and prohibited to every State, as well as to the United States, the assumption of any debt or obligation incurred in aid of insurrection or rebellion, and the recognition of any claim for slaves lost or emancipated. The fifteenth prohibited the abridgment or denial of the right to vote of citizens of the United States on account of race, color, or previous condition of servitude. Full power was expressly given to Congress to enforce these several amendments by legislation.

All these last articles had for their permanent object the establishment of universal personal liberty, and the fundamental rights of citizenship everywhere within the Union. The ratification of the thirteenth article was proposed by Congress February I, I 865, and was 
proclaimed on the I 8 th of December, I 865 ; of the fourteenth was proposed June I6, I 866 , and proclaimed on the 28 th of July, I 868 ; of the fifteenth was proposed February 27, I 869, and proclaimed on the 30 th of March, I870.

The foregoing fifteen articles of amendment are the only modifications of the work finished on the 17 th of September, I 787 , of the propriety of which, time, events, and argument have convinced the American people. The first ten articles were not so much amendments of constitutional provisions as they were a declaration of ungranted rights which the national government did not claim. The eleventh settled in favor of the States a question of their suability in court which had been debatable. The tide of constitutional opinion had thus far flowed towards the rights of the States, and they were satisfied.

In later years, some of the States began to assert rights of separate and final judgment against the supremacy of acts of Congress and of the national courts, which were inconsistent with the intention of the Constitution and of its founders. The tide of public opinion turned with the exposure of the new dangers threatening national institutions, and flowed strongly towards the further protection of that Union which, as Madison had advised New York, was indissoluble. Under this impulse the last three 
articles were adopted, in order to put new powers into the hands of the common government, and to place the most important rights of personal liberty and of American citizenship under the protection of the national shield. This was a work impossible to the fathers by reason of slavery; and was only accomplished by their descendants at the cost of vast treasure and richer blood.

The passing generation of men may therefore proudly claim to have added something to the rich legacy which our ancestors bequeathed a hundred years ago. Let us hope that as century shall follow century into the unmeasured flood of time, the uncounted millions who shall inherit this Western World will maintain their allegiance to the Constitution and Union with equal zeal, and with all the support of heart and tongue and sword.

"Thy sun is risen, and shall not set

Upon thy day divine!

Ages of unborn ages yet,

America, are thine!" 
APPENDIX 


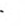




\section{APPENDIX}

Congressional Calls on the President for Papers AND INFORMATION

THE right of either House of Congress, or of both Houses concurrently, to call on the President for papers or other specific official information, is not provided for by the Constitution. It does not appear to have been discussed in the Convention. The only constitutional provision even remotely relating to the subject simply declares that the President "shall from time to time give to the Congress information of the state of the Union."

Nevertheless, each House has at different times made such demands upon the Executive, and the constitutional duty of the President in respect to such calls has been the subject of discussion. In most cases of the exercise of this claim for information the Executive has yielded, because it was for legitimate objects and in the ordinary course of legislative proceeding. But at other times it has proceeded from mere political hostility, and had for its object to provide means for party assaults upon the Administration or its policy, irrespective of the public interests involved. In cases of the latter kind, and even in other cases where the Executive has complied with the demand, he has been careful to assert his constitutional right of independent decision, and to refuse compliance in his official discretion.

The question first arose during the presidency of Washington: In March, I796, the House of Representatives called on the President for instructions given to the United States Minister preliminary to Jay's Treaty, which had been already ratified, "except such as any existing negotiation may render improper to be disclosed." Madison 
proposed a further exception of "such as were inconsistent with the interest of the United States to disclose." Madison's amendment was rejected by a majority of 10 votes. The House on March 24 passed the Resolution by a vote of 62 to 37 .

On the 3 oth of March Washington responded by a Message of refusal. Among his reasons he declared that " as it is essential to the due administration of the government that the boundaries fixed by the Constitution between the different departments should be preserved, a just regard to the Constitution and to the duty of my office, under all the circumstances of this case, forbids a compliance with your request;" and he added the following argument:-

"Having been a member of the General Convention and knowing the principles on which the Constitution was formed, I have ever entertained but one opinion on this subject; and from the first establishment of the government to this moment my conduct has exemplified that opinion - that the power of making treaties is exclusively vested in the President, by and with the advice and consent of the Senate, provided two thirds of the senators present concur ; and that every treaty so made and promulgated thenceforward became the law of the land. It is thus that the treaty-making power has been understood by foreign nations, and in all the treaties made with them we have declared and they have believed that, when ratified by the President, with the advice and consent of the Senate, they became obligatory. In this construction of the Constitution every House of Representatives has heretofore acquiesced; and until the present time not a doubt or suspicion has appeared, to my knowledge, that this construction was not a true one. Nay, they have more than acquiesced; for till now, without controverting the obligation of such treaties, they have made all the requisite provisions for carrying them into effect. 
"There is also reason to believe that this construction agrees with the opinions entertained by the state conventions when they were deliberating on the Constitution, especially by those who objected to it because there was not required in commercial treaties the consent of two thirds of the whole. number of the members of the Senate instead of two thirds of the senators present, and because in treaties respecting territorial and certain other rights and claims the concurrence of three fourths of the whole number of the members of both Houses, respectively, was not made necessary."

"If other proofs than these and the plain letter of the Constitution itself be necessary to ascertain the point under consideration, they may be found in the journals of the General Convention, which I have deposited in the office of the Department of State. In those journals it will appear that a proposition was made 'that no treaty should be binding on the United States which was not ratified by a law' and that the proposition was explicitly rejected."

President Monroe was called upon by a Resolution of the House of Representatives, January 4,1825 , for documents relating to the conduct of naval officers and other public agents in South America. He replied by Message of January 10, 1825 , declining compliance with it as inconsistent with the public interest.

The Senate, on the 1 ith of December, I833, on motion of Mr. Clay and by a vote of 23 to 18 , called upon President JACKSON to communicate to the Senate "a copy of the paper which has been published" over his signature and which related to the removal of the deposits from the United States Bank.

In his Message of refusal Jackson declared the Executive to be "a coördinate and independent branch of the government equally with the Senate," etc., etc. He added the following declaration: "Knowing the constitutional 
rights of the Senate, I shall be the last man under any circumstances to interfere with them. Knowing those of the Executive, I shall at all times endeavor to maintain them agreeably to the provisions of the Constitution and to the solemn oath I have taken to support and defend it.

"I am constrained, therefore, by a proper sense of my own self-respect and of the rights secured by the Constitution to the executive branch of the government to decline a compliance with your request."

The Senate, on the 12 th of June, 1834 , called on President JACKson to transmit to the Senate an official communication from him to Andrew Stevenson relating to his nomination as E. E. and M. P. to Great Britain. The President replied June 13 , as follows :-

"As a compliance with this Resolution might be deemed an admission of the right of the Senate to call upon the President for confidential correspondence of this description, I consider it proper on this occasion to remark that I do not acknowledge such a right; but to avoid misrepresentation $I$ herewith transmit a copy of the paper in question."

President JACKson also (January 6, i 835) refused compliance with a Resolution of the House of Representatives demanding certain information.

$\mathrm{He}$ asserted the right of the Executive to refuse compliance with a demand of the Senate for copy of an official report, as found in his Message of January I 3,1835 .

But for a complete exposition of President Jackson's views on the subject, see his Message of February ro, $\mathbf{1} 835$, to the Senate, in which among other emphatic declarations is found the following:-

"This is another of those calls for information made upon me by the Senate which have, in my judgment, either related to the subjects exclusively belonging to the Executive Department or otherwise encroached on the 
constitutional powers of the Executive. Without conceding the right of the Senate to make either of these requests, I have yet, for the various reasons heretofore assigned in my several replies, deemed it expedient to comply with several of them. It is now, however, my solemn conviction, that I ought no longer, from any motive nor in any degree to yield to these unconstitutional demands. Their continued repetition imposes on me, as the representative and trustee of the American people, the painful but imperious duty of resisting to the utmost any further encroachment on the rights of the Executive."

In March, 1848, President TYLER answered a request by the House of Representatives addressed to the President and heads of the several departments for certain information by a refusal, it not being "consistent with the rights and duties of the Executive Department." He said in his Message, "It becomes me, in defence of the Constitution and laws of the United States, to protect the Executive Department from all encroachments on its powers, rights, and duties."

On January 31,1843 , he again refused compliance with the Resolution of the House requesting certain reports, and reasserted the constitutional discretion of the Executive in such cases; and again in February, while granting the request of the House of Representatives, he reserved the like discretion.

President PoLK, in March, 1845, courteously denied the request of the Senate for certain information touching the President's action respecting the annexation of Texas. $\mathrm{He}$ also in January, $\mathbf{1} 848$, denied a request from the House for certain instructions given to Officers of the Army or Navy of the United States, concluding his Message in the following words: "I regard it to be my constitutional right and my solemn duty under the circumstances of this case to decline a compliance with the request of the House contained in their Resolution." 
President FILLMORE on several occasions also declined the requests of the Senate.

President Cleveland, in his Message of March $\mathrm{r}, \mathrm{I} 886_{\mathrm{q}}$ against the numerous requests and demands of the Senate upon the different departments of the government for information and documents, says:-

"My oath to support and defend the Constitution, my duty to the people who have chosen me to execute the powers of their great office and not to relinquish them, and my duty to the Chief Magistracy, which I must preserve unimpaired in all its dignity and vigor, compel me to refuse compliance with these demands."

On the 16 th of May, 1896 , the Senate called on President Cleveland for certain correspondence, a portion of which he transmitted; as to the remainder, he said : -

"It being, in my judgment, incompatible with the public service, I am constrained to refrain from communicating to the Senate at this time copies of the correspondence described in the third paragraph of said Resolution."

From the foregoing illustrations it appears that the Constitution has been practically interpreted in a manner to exclude any right in either House to dictate the action of the Executive in this respect. Hence the request by either House, addressed to the President or to any Executive Department, for information should never be in the form of an order, direction, or instruction, unless it be a duty imposed by some express law. 


\section{HISTORY OF THE MONROE DOCTRINE}





\section{I}

THE HISTORY OF THE MONROE DECLARATION OF 1823

IN every conflict of European with American territorial possession on the two western continents, our countrymen make their appeal to the Monroe Doctrine. It is quoted as the supreme, indisputable, and irreversible judgment of our national Union. Among the very few political maxims which serve to guide public opinion in our country, this ranks as the chief. Aside from the traditions which preserve our neutrality in foreign wars and complications, and extend equality of commercial advantages to all friendly nations in their intercourse with us, it may be said to indicate the only established idea of foreign policy which has a permanent influence upon our national administration. It has also taken fast hold on the popular mind. A President of the United States, justly appealing to it in an emergency, could not fail of unanimous following of patriotic citizens, even in presence of a consequently impending war. It touches the instinct of national safety, and of pride in our national institutions. A sagacious observer of public 
opinion will not fail to mark how a simple appeal to this "doctrine," in a given case, holds the general judgment in suspense until it is clear whether its principles are involved. If that question is affirmatively solved, the judgment becomes resolute and unchangeable.

In presence of this powerful sentiment, swaying a great people as well as their government, it is not surprising that the application of the declaration often comes into discussion on the floor of Congress and in the press. It becomes more and more important that it should be understood, in respect to its origin and purpose. When legitimately directed, Europe can never complain of surprise or wrong, for her governments have had notice of it from the United States for more than three quarters of a century. Indeed, its origin partially, and its occasion wholly, were in Europe. While it has never received express legislative sanction at Washington, this is in no degree to be attributed to failure of approval. It has been the natural consequence of a desire, on the part of Congress, to refrain from committing itself in an academic sense, merely - to a general declaration. They preferred to leave the initiative of its application, in any complication of circumstances, to the executive organ constitutionally charged with the conduct of foreign relations, while themselves retained their con- 
stitutional function of enforcing it, in their ultimate discretion, by a declaration of war.

So early as January, i 8 I I, President Madison communicated to Congress some correspondence indicating an intention on the part of Great Britain to acquire possession of certain territory claimed as a part of Spanish Florida, and situated on our southern boundary.

In his accompanying message he said: "I recommend to the consideration of Congress the seasonableness of a declaration that the United States could not see without serious disquietude any part of the neighboring territory in which they have in different respects so deep and so just a concern pass from the hands of Spain into those of any other foreign power."

This recommendation was made twelve years before the Declaration of Monroe, and was suggested by the menace to our national safety if another European power should obtain new possessions of territory upon our borders. It received the sanction of Congress at the same session.

But the registered birth of the historical declaration was in December, I823. It had both an international and national period of gestation, the history of which is full of interest. Our government was extremely fortunate in 
having at that time for Secretary of State John Quincy Adams, and for its envoy in London, Richard Rush, of Pennsylvania. The former had not only the advantage of early experience with his father in Europe, but had represented this country in the Netherlands, Portugal, Prussia, Russia, at the Treaty of Ghent, and finally at London. He was thus thoroughly informed of the ways of European diplomacy, and of the spirit of the European powers. To this knowledge he added the firm will and resolute patriotism which have long characterized that distinguished family. Mr. Rush, as his agent at the court of St. James, joined to superior scholarly attainments the agreeable manners which win friendship, the truthful qualities which win confidence, and the careful precision in action which saves governments from difficulties and chiefs from annoyance. Mr. Gallatin was our envoy accredited at Paris, but was, during this period, on leave, and in the United States. Mr. Middleton was the minister of the United States at St. Petersburg, where the discussion of the principle was also in part conducted.

The situation in Europe was uneasy, and among its western nations was some anger and a growing jealousy. The eastern members of the "Holy Alliance" were haughtily confident, having autocratic Russia at their head 
and subjugated France at their feet. One Bourbon had been enthroned at Paris by foreign arms, and another, at Madrid, had replaced a Bonaparte. When the latter came to that throne, with the Spanish people rebellious, the Spanish-American colonies had revolted; and, on the restoration of the Bourbon monarch, had resolved to maintain their separation, with independent governments. In 1822 , our government, on full consideration, recognized their independence, and resolved thenceforth to use its entire influence to secure the recognition of the new states by Europe. Spain, during the Napoleonic confusion, had tasted the sweets of a more liberal national life; and the Cortes had imposed on Ferdinand VII, after his restoration, a constitution derived from popular right, and inconsistent with the divine right of kings. The royalists, inspired by the French government, created an insurrection in behalf of the Bourbon principle; but they were defeated. The successful introduction of popular right into Spain was rebellion against the principle of the Holy Alliance. The three great eastern powers withdrew their ministers from the government controlled by the Cortes, and left to the French monarch the wretched distinction of restoring absolutism to the throne of Spain. On the 28th of January, $\mathrm{IS}_{23}$, he announced, in his speech from the throne to 
the French Chambers, that he had ordered the recall of his minister at Madrid, and that a "hundred thousand French troops were ready to march to preserve the throne of Spain to a descendant of Henry IV, to preserve this noble kingdom from its ruin, and to reconcile it to Europe." He further declared that "Ferdinand VII should be free to give to his people the institutions which they can only hold from him, and which, while assuring their repose, would dissipate the just disquiet of France."

Here was the bold annunciation of that claim of the Holy Alliance to the divine right of monarchy, and to interference against free governments, which was the occasion of serious alarm to the American Cabinet, and to which portions of the message of Mr. Monroe were a response. This despotic principle extended equally to Spanish subjects in Spain, and to her late subjects in America. It might at any time be claimed to extend to the suppression of this republic, as deriving its constitution from an unlawful authority, - from a rebellious people, - and as furnishing an example which caused disquiet to lawful monarchies.

In August, 1823, the French troops had gained control of so much of Spain as indicated the final success of the purposes of the Holy Alliance and the military triumph of 
France. Already was the question raised in the English Foreign Office what would be the next step of Spain and of France, and whether the Holy Alliance itself would not proceed to the reclamation of Spanish America. England, in consequence of the abolition of the old Spanish colonial restrictions on trade, had already opened a large and profitable com. merce with Spanish America. This would be lost if there should be a restoration of colonial dependence. This, therefore, was not to be desired. On the other hand, England was the greatest proprietor of dependent colonies on the globe. It was not for her government to assume the attitude of encouragement to colonial revolt, or of premature recognition of the independence arising from it. But, if not recognized, would not France join her army and navy to the forces of Ferdinand, and so restore European control over the former Spanish domains in America? In that case, would not France demand and receive large compensation in territory and colonial dependence, and in commercial intercourse, for her expenditures in the Peninsula and beyond seas? And so would appear on the American scene a contestant more vigorous and more formidable than Spain - a more dangerous rival in both commercial and military affairs.

These were anxious questions with the Eng. 
lish Cabinet in the summer of 1823 , when Mr. Canning, as English Minister for Foreign Affairs, on the r6th of August, in conversation with Mr. Rush, opened the inquiry whether the United States would not join England in the policy of disclaiming all intention of appropriating to themselves any portion of the Spanish possessions in America; of regarding the question of their independence as practically settled; and of opposition to the acquisition of any of these possessions by France, either by conquest or by cession. These views of the English government had been, in part, presented to France in April, through a note addressed by Mr. Canning to the British ambassador at Paris. French military successes in Spain appear to have increased the fears of the British government, and to have inspired their minister with the thought of securing an ally for their protest in the government of the United States. He believed the moral effect of their concurrent representations, with their large share of maritime power, would be of itself sufficient to prevent the results which were apprehended. He himself believed " that now all America might be considered as lost to Europe, so far as political dependence was concerned."

On the 2oth of August, I823, Mr. Canning again presented the subject in a private and 
confidential note to Mr. Rush, evidently carefully worded and offered with an air of great frankness, in which he declares the following points of English policy, and asks the United States to join with England in making them public in some suitable form. These points are :

"First. That we conceive the recovery of the colonies by Spain to be hopeless.

"Second. We conceive the question of the recognition of them as independent states to be one of time and circumstances.

"Third. We are, however, by no means disposed to throw any impediment in the way of an arrangement between them and the mother country by amicable negotiation.

"Fourth. We aim not at the possession of any portion of them ourselves.

"Fifth. We could not see any portion of them transferred to any other power with indifference.

"If these opinions and feelings are, as we firmly believe them to be, common to your government with ours, why should we hesitate mutually to confide them to each other, and to declare them in the face of the world?"

The manner of bringing the United States to declare itself on point four is worthy of attention. The despatch of Mr. Rush communicating this "unofficial" note was received by 
Mr. Adams October gth. Mr. Rush, in his reply to Mr. Canning, accepts in substance these declarations, choosing his own form of expression, and excluding the second, as the recognition by the United States was already accorded; but disclaims authority from his government as to the manner of its avowal of the principles and sentiments involved.

On the $23 \mathrm{~d}$ of August, 1823, as reported in Mr. Rush's despatch of August 28 (also received by Mr. Adams October 9), Mr. Canning, by way of urgency, addressed another note to Mr. Rush, in which he advised him of information received that, after the French success in Spain, there was an intention to assemble a congress, or to devise other concerted action upon the affairs of Spanish America. To this note Mr. Rush replied in like spirit as before, always insisting upon the importance of an acknowledgment of the independence of the American states by England, and intimating that he would take great responsibility on himself in following the direction suggested by Mr. Canning, if such acknowledgment should be made at once; and this intention he reported in his despatch to Mr. Adams.

Under date of 3 Ist of August Mr. Canning addressed another confidential note to Mr. Rush, who communicated it to the Department with his despatch of September 8 (re- 
ceived by Mr. Adams November 5), in which he withdraws any official and decisive character of his former notes, asking that they be treated not as a proposition, but as evidence of the nature of a proposition which he would have desired to make if Mr. Rush had been provided with authority to entertain it.

Mr. Canning again, on the I8th of September (reported by Mr. Rush under date of $I$ gth, and received by Mr. Adams November 3), revived the subject with Mr. Rush at great length and with great urgency; and inquired whether, if England should acknowledge the independence of the Spanish-American states, that would affect Mr. Rush's action upon the declarations proposed to be made. To this Mr. Rush stated frankly that, while he had no specific powers to unite in such declaration, he would in that case stand upon his general powers, and "would put forth with Great Britain the declaration to which he had invited him," and would do so "in the name of his government, and consent to its being promulgated to the world."

On the 26th of September, Mr. Canning asked Mr. Rush whether he could not assent to the proposals on a promise by Great Britain of the future acknowledgment of the independence of the South American states. To this Mr. Rush gave a decided refusal. 
It appears from Mr. Rush's despatch of October Io (received by the State Department November 19) that he was then convinced that the whole effort of Mr. Canning was made in the interests of Great Britain as against France and Russia, and that England had no interest in American independence except so far as it concerned British interests and ambition; and that her government was even in general sympathy with the Holy Alliance in its efforts to suppress popular reforms in Europe. $\mathrm{He}$ considers the propositions as abandoned by England, and the discussion as at an end. $\mathrm{He}$ awakens to the fact that British policy will be dictated exclusively by British commercial interests, irrespective of colonial or national rights.

Another interview with Mr. Canning on the $24^{\text {th }}$ of November, reported by Mr. Rush under date 26th November, explains the subsequent action of the English Secretary. Coming to no understanding with Mr. Rush, he decided to proceed directly to the French government for an exchange of views on the subject of Spanish America. And in Mr. Rush's despatch of December 27, I823, he communicates to his government the memorandum of the conference between the French ambassador in London, Prince de Polignac, and Mr. Canning, which was begun October 9 and concluded October 12. On the British side it was declared that the 
restoration of the colonies to Spain was hopeless, and further war useless. England would continue neutral, but the union of any foreign power with Spain in the attempt to recover the colonies would present a new question on which England would be free to act. The government disclaimed any desire to appropriate to itself territory or exclusive advantages, and intimated its intention to recognize the new states; and, in presence of any foreign force or menace in the Spanish-American dispute, they would be recognized without delay.

On the part of France it was declared that the claim of Spain was hopeless, that France had no intention or desire to avail itself of the present state of the colonies, or of the relations between France and Spain, to appropriate to herself any part of the Spanish possessions in America, or to obtain exclusive privileges ; and that she abjured all intention to act by force of arms against the colonies. France was in favor of a congress of the allies to facilitate reconciliation between Spain and her colonies, and was opposed to any recognition of the new states at present.

Mr. Canning further remarked upon the impropriety of a representative congress discussing Spanish-American affairs "without calling to their counsels a power so eminently interested in the result as the United States of 
America." To this the Prince avowed himself without instructions, but, personally, saw no in. superable difficulty in such an association. In point of fact, an invitation to a congress of the powers, to be held at Paris, to consider SpanishAmerican affairs, was issued by the Conde de Ofalia on the part of the Spanish government, under date of 26th December, 1823 .

All these despatches of Mr. Rush, up to and including that of October 10 , which announced the abandonment of the propositions, were received by Mr. Adams prior to November 20, and, of course, in advance of the message of Mr. Monroe.

But it was neither Mr. Rush's despatches nor Mr. Canning's proposals which first presented the question of principle to the American government. Mr. Adams possessed not only a trained intellect, inspired by ardent love of our republican institutions, but a perfect acquaintance with the spirit, methods, and tendency of European diplomacy. No man could better appreciate the menaces to human liberty everywhere, and to all rights of the people, as threatened by the several congresses of the allied powers, and especially by their circular of December 5,1822 , in which the allied monarchs announced their resolution " to repel the maxim of rebellion, in whatever place, or under whatever form, it might show itself." He knew that 
the unorganized riot of insurrection and the organized riot of despotism were alike destructive of popular liberty. Just now, after the final overthrow of all the Bonapartes, it was the riot of despotism. It was important to keep these despotic powers from our continent, if possible. An ocean between was safer than contiguity of any kind. There were many leagues of little known and much disputed boundary on our northwestern coast, claimed by the United States, by England, and by Russia. The Russian minister at Washington wanted to know what instructions our Secretary was going to send to Mr. Middleton. Mr. Adams answered him sturdily, on July I 7, I823, that "we should contest the right of Russia to any territorial establishments in this continent; and that we should assume distinctly the principle that the American continents are no longer subjects for any new European colonial establishments."

Here, already announced to the chief of the Holy Alliance more than four months prior to President Monroe's message, was one branch of the Monroe Declaration. In his message of December following, it took authoritative form as follows: "The American continents, by the free and independent condition which they have assumed and maintain, are henceforth not to be considered as subjects for future colonization by any European power." 
While Mr. Canning was anxiously observing the darigers which threatened British commercial interests in America from the probable interferences of the allied powers in SpanishAmerican affairs, and while Mr. Rush was writing his urgent despatches, the Russian Premier, Count Nesselrode, was dictating certain despatches to his minister at Washington, Baron Tuyl, touching the same affairs. These despatches were communicated to Mr. Adams in November, about the time of the arrival of the last despatches of Mr. Rush on the subject of the Canning proposals. In stating the views of the Czar, Count Nesselrode took occasion to present the political ideas of the allied powers, as well as the Russian view of the Spanish claim to the revolted American continent. Thus from various sides were concentrating upon Mr. Adams, in the autumn of I 823, notes of the preparation of a conflict which was generally expected, and in which the mailed hand of the Holy Alliance would strike the new continents, and would confront the principles of European despotism with the principles of American liberty, in close and irrepressible combat. The stubborn patriotism of Adams did not for a moment falter. "My purpose would be," he says of himself, " in a moderate and conciliatory manner, but with a firm and determined spirit, to declare our dissent from 
the principles avowed in those communications, and assert those upon which our government is founded; and while disclaiming all intention to propagate them by force, and all interference with the affairs of Europe, to declare our expectation and hope that the European powers will equally abstain from the attempt to spread their principles in the American hemisphere, or to subjugate, by force, any part of these continents to their will."

Here again is seen the gestation in Mr. Adams's fertile and resolute mind of the other branch of the Monroe Doctrine, and he notes that his "views were approved by the President."

Prior to the $25^{\text {th }}$ of November, the Secretary of State had prepared his draft of a reply " intended as a firm, spirited, and yet conciliatory answer to all communications lately received from the Russian government, and at the same time an unequivocal answer to the proposals made by Canning to Mr. Rush. It was meant also to be eventually an exposition of the principles of this government, and a brief development of its political system as henceforth to be maintained : essentially republican - maintaining its own independence, and respecting that of others; essentially pacificstudiously avoiding all involvement in the combinations of European politics, cultivating 
peace and friendship with the most absolute monarchies, highly appreciating and anxiously desirous of retaining that of the Emperor Alexander; but declaring that, having recognized the independence of the South American states, we could not see with indifference any attempt by European powers, by forcible interposition, either to restore the Spanish dominion on the American continents, or to introduce monarchical principles into those countries, or to transfer any portion of the ancient or present American possessions of Spain to any other European power."

At this time, it appears by a remark of $\mathrm{Mr}$. Adams, the President had already prepared a paragraph of his message relating to this sub. ject, to which his despatch was to be "conformable." The draft of Mr. Adams was the subject of repeated discussions at the meetings of the Cabinet. President Monroe thought it too strong in its expressions. He was cautious, even timid, from fear of offending the Russian emperor, and believed it imprudent to state, as Mr. Adams desired, the principles of our republican government in answer to Count Nesselrode's statement of imperial principles. Messrs. Wirt, Calhoun, and Southard took part in the discussions, and Mr. Gallatin was called in for counsel.

Very soon after the reception of the Can- 
ning proposals from Mr. Rush, the President had communicated them to the venerable patriot at Monticello for his opinion. Mr. Jefferson had represented his country at Paris and at London, and both as President and as a retired citizen was well advised of the course of European affairs. Nothing had ever shaken his republican faith or his sincere patriotism. Mr. Monroe confided to him the correspondence which contained the germs of such an important feature of American policy, and which possibly involved the independence of the Spanish-American republics, with the fate of liberty itself in the western hemisphere. On the $24^{\text {th }}$ October, 1823, Mr. Jefferson, at the age of eighty years, responds with the vigor and vivacity of youth:

"The question presented by the letters you have sent me is the most momentous which has ever been offered to my contemplation since that of Independence. . . .

"Our first and fundamental maxim should be, never to entangle ourselves in the broils of Europe. Our second, never to suffer Europe to intermeddle with cis-Atlantic affairs. . . .

"Great Britain is the nation which can do us the most harm of any one, or all on earth; and with her on our side we need not fear the whole world. With her, then, we should most sedulously cherish a cordial friendship; and nothing 
would tend more to knit our affections than to be fighting once more, side by side, in the same cause. Not that I would purchase even her amity at the price of taking part in her wars. But the war in which the present proposition might engage us, should that be its consequence, is not her war, but ours. Its object is to introduce and establish the American system, of keeping out of our land all foreign powers - of never permitting those of Europe to intermeddle with the affairs of our nations. It is to maintain our own principle, not to de. part from it. And if, to facilitate this, we can effect a division in the body of the European powers, and draw over to our side its most powerful member, surely we should do it. But I am clearly of Mr. Canning's opinion, that it will prevent instead of provoking war. With Great Britain withdrawn from their scale and shifted into that of our two continents, all Europe combined would not undertake such a war."

After speaking of the question of the United States acquiring some Spanish-American domains, and finding it impracticable, he continues:-

"I could honestly, therefore, join in the declaration proposed, - that we aim not at the acquisition of any of those possessions, that we will not stand in the way of any amicable arrangement between them and the mother 
country; but that we will oppose, with all our means, the forcible interposition of any other power as auxiliary, stipendiary, or under any other form or pretext, and, most especially, their transfer to any power by conquest, cession, or acquisition in any other way."

By desire of the President, Mr. Jefferson transmitted the Rush correspondence to that other experienced statesman of Virginia, Mr. Madison, whose retirement at Montpelier, and his age of seventy-two years, could not prevent patriotic appeals to his wisdom and experience. The junior of Mr. Jefferson by eight years, the response of Mr. Madison indicates a mind by far senior to that of his more vivacious compatriot. His logical mind accepts the situation as portrayed, and sees clearly the necessity "to defeat the meditated crusade" against American independence. Under date of October 30 , I 823, he writes to President Monroe:-

"It is particularly fortunate that the policy of Great Britain, though guided by calculations different from ours, has presented a cooperation for an object the same with ours. With that coöperation we have nothing to fear from the rest of Europe, and with it the best assurance of success to our laudable views. There ought not, therefore, to be any backwardness, I think, in meeting her in the way she has proposed; keeping in view, of course, 
the spirit and forms of the Constitution in every step taken in the road to war, which must be the last step, if those short of war should be without avail."

In a note to Mr. Jefferson, written a few days later, he gives expression to a sentiment which ran as an undercurrent, and still runs as an undercurrent, of all the policy under discussion. He says: "In the great struggle of the epoch between liberty and despotism, we owe it to ourselves to sustain the former - in this hemisphere, at least."

We now see collected before President Monroe, in anticipation of the final form of his famous declarations, the motive forces and opinions which modified or directed the historical result. Mr. Canning's proposals, sometimes hesitating, sometimes eager, always auxiliary to some unavowed interest of England; Mr. Rush's generous efforts to secure South American independence by British recognition; Russia's bold enunciation of despotic principles and of the right of the Spanish monarch to reclaim his rebellious provinces; Mr. Adams's robust counterblast, declaring the inalienable rights of the people; the vivacious counsels of Jefferson's liberalism, and the sober advice of Madison's trained and logical wisdom, - all these contributed to shape the other branch of the Monroe Declaration, as follows:- 
"We owe it to candor, and to the amicable relations existing between the United States and the allied powers, to declare that we should consider any attempt on their part to extend their system to any portion of this hemisphere as dangerous to our peace and safety. With the existing colonies or dependencies of any European power we have not interfered, and shall not interfere; but with the governments who have declared their independence and maintained it, and whose independence we have, on great consideration and on just principles, acknowledged, we could not view any interposition for the purpose of oppressing them, or controlling in any other manner their destiny, by any European power, in any other light than as the manifestation of an unfriendly disposition toward the United States. . . .

"It is impossible that the allied powers should extend their political system to any portion of either continent without endangering our peace and happiness. ...

"It is equally impossible that we should behold such interposition in any form with indifference."

The effect of this Declaration in Europe was all that could have been desired by the patriotic statesmen who contributed their counsel to its adoption. The message arrived in England on December 24, 1823, twenty-two days 
from its delivery to Congress. On the $2 \mathrm{~d}$ of January, Mr. Canning told Mr. Rush that the principle declared in the message, that the American continents were not to be considered as subjects for future colonization by any of the powers of Europe, greatly embarrassed the instructions he was about to send to the British ambassador at St. Petersburg, touching the northwestern boundary. He believed that Great Britain would combat this Declaration of the President with animation.

Mr. Rush, under date of January 6, 1824, writes:

"All the Spanish-American deputies now in London have waited upon me since its arrival, testifying the high and grateful sense they entertain of the service which its decisive tone in regard to Spanish-America has rendered to their respective countries."

The Spanish invitation of December 26, for a congress touching her late American possessions, was paralyzed. The whole message, on its arrival in London, excited great attention. "It was upon all tongues; the press was full of it; the Spanish-American deputies were overjoyed; Spanish-American securities rose in the stock market, and the safety of the new states from all European coercion was considered as no longer doubtful." The document received the approval of the calm judgment 
of Mr. Madison in April, 1824 , in the following terms:-

"I never had a doubt that your message, proclaiming the just and lofty sentiments of ten millions, soon to become twenty, enjoying in tranquil freedom the rich fruits of successful revolution, would be received in the present crisis of Europe with exulting sympathies by all such men as Lafayette, and with envenomed alarm by the partisans of despotism. The example of the United States is the true antidote to the doctrines and devices of the Holy Allies; and if continued, as we trust it will be, must regenerate the Old World, if its regeneration be possible."

Its effect upon the then pending negotiations with Russia was so favorable that the convention of 1824 was concluded, in the spring of that year, by the withdrawal on the part of the emperor of his pretensions to exclusive trade and navigation on the northwest coast, and by fixing the parallel of $54^{\circ} 40^{\prime}$ as the line between the permissible establishments of the respective countries. Between no two governments of the civilized world was the contrast so divergent in all their political principles, traced from their foundation through all their development, as between the United States and Russia. Yet between the American Republic and no other country has there 
been a longer continued or more unbroken friendship. The American diplomatist in Europe is often asked for an explanation of this fact. Perhaps the answer may be found in a remark of the late Czar to a former minister of the United States. Said he: "Your government and mine are the only logical governments in the world. Either the whole people, or one man, is entitled to rule." In I 823 the Holy Alliance took the despotic view, and maintained it in Europe. The government of our country took the popular view, and declared through the President their resolution to maintain it on this hemisphere. Each respected the sense of right which animated the other, and each has limited itself to its own sphere; and more recently Russia has wholly withdrawn from this continent, with assignment of all her rights to this republic.

NotE. - In the dispute which arose in 1895 respecting the forcible extension of the British boundary into Venezuela, the British government made an important statement respecting the Monroe Declaration, in its correspondence with the Washington government, which is worthy of record in this history. It is as follows :-

"In declaring that the United States would resist any such interference if it was contemplated, President Monroe adopted a policy which secured the entire sympathy of the English government of that date. . . . They [her majesty's government in I895] fully concur with the view which President Monroe apparently entertained that any disturbance of the existing territorial distribution in that hemisphere by any fresh acquisitions on the part of any European state would be a highly inexpedient change." 


\section{II}

THE MONROE DOCTRINE IN LATER YEARS

Such was the evolution of the Monroe Declaration. That Declaration was especially applicable to the international conditions then existing. Its formula was more limited than that recommended by some of the chief counsellors of the President. He, acting under the influence of his great responsibility and his characteristic caution, was content to satisfy the immediate demand of his time.

Mr. Quincy Adams and Mr. Jefferson, with far-reaching foresight, would establish the principle in terms broad enough to embrace the probable conditions of the future.

It remains to show the later expansion of the principle, and to affirm the necessity of its application to-day in the broader sense indicated by both Mr. Jefferson and Mr. Adams.

The United States Cabinet of 1823 was alarmed by the despotic announcement of the Powers at Laybach and at Troppau. These furnished a powerful motive of its decision. The imperial coalition had proclaimed at Laybach that they regarded every reform effected by means of an insurrection as null, and con- 
trary to the public law of Europe; and that they would pursue rebellion everywhere, and under whatever form it should show itself. At Troppau they went so far as to affirm that by divine law European nations had the imprescriptible right to put themselves in open hostility against states which, by a change of their institutions or their government, offered a dangerous example. These principles clearly touched the life of every American republic; and in 1823 they were forcibly applied to the suppression of the parliamentary system of the Spanish monarchy, and then threatened the independence of the Spanish-American colonies. It is quite credible that at that period only the great waste of the Atlantic waters saved the American republics from a conflict for their national life. Even this wide desert boundary did not save Mexico so late as I $864-$ 65 from the vital struggle between European and American political systems. Napoleon III, believing the United States, then engaged in civil war, to be disabled from a military enforcement of the Monroe Declaration, ventured upon the fatal attempt to impose an European system of empire upon our neighboring republic of Mexico. The imperial disaster which followed will probably serve as a sufficient warning against any similar undertaking in the future. 
It may be admitted that the principles in question, as declared by Mr. Monroe, were limited to these two points: First, that no foreign power should thereafter establish a colony within the territories of any of the de facto independent states of America, meaning thereby to include all parts of both continents not at that time held as colonial possessions. Second, that no European power should attempt by force to introduce monarchical institutions into any American territory, or otherwise interfere to oppress the American states, or control their independent development. The French emperor's action in Mexico was a violation of the latter principle.

Señor Calvo, in his late treatise on international law, after a review of the principles of Mr. Monroe's message, of the international conditions which preceded it, and of the Congressional discussions which followed it, states its points touching colonization as follows: "First, that the European colonial system is inapplicable to the new situation of America, because all parts of the American continents are inhabited by civilized nations, which, in respect to their independence, and to alien sovereignty over them, have absolutely the same title as European nations. Second, that the questions of boundary between the ancient European establishments and the new Ameri- 
can states can only be settled according to the general principles of international law. Third, that the first occupation or first exploration creates now no longer any right of sovereignty over the American territories, whose rightful sovereignty can only result, in the future, from a treaty or from war. In this last point of view we may say that American public law is the same as that of Europe, and rests exactly upon the same basis."

If Europe had frankly accepted Mr. Monroe's declarations in their spirit, we should have had no occasion to reaffirm his principles, or to enlarge the terms of their statement. But Europe has notdone so. Chili has had complaints touching colonizations attempted on her extreme southern and inhospitable borders. England has asserted claims in Central America which have caused us troublesome and dangerous complications. France and Austria, at first assisted by Spain and England, have made a serious assault upon Mexico, to control her independence and to change her government. They have not respected our demand for noninterference in the internal affairs of this hemisphere. Some of them still seek possessions here. They have forced us to vigilance. Calvo is probably right in saying that the letter of the Monroe Declaration leaves open the question of colonial acquisitions by war or by treaty. 
Nevertheless, beyond our own territory, our interest is exclusively with the fact of colonization or acquisition, no matter by what mode or claim of right. Our interests are affected by the fact. Whether they change a sovereign jurisdiction on a part of our continent, or effect other interference, by direct war, or by the instrumentality of a charter granted by them to their subjects, with retained power of control; whether they act by intimidation, by force, by finesse, or by purchase, it is the resulting fact with which we have to deal. It is that which touches our interests, and changes our existing relations with the territory affected.

Cannot a European nation, then, make wars or treaties with an independent American state? Certainly. But should their result involve consequential detriment to our national interests, or threaten our national security, public law and precedent concede to us the right to protest, and to enforce that protest by defensive action. European diplomacy is full of precedents for the right of intervention in such cases. The entire "balance-of-power" theory, whose discussions pervade the modern diplomatic history of Europe, starts from that principle. We need to go no farther to seek a precedent than in Mr. Canning's proposals to Mr. Rush for joint action against the anticipated projects of France in 1823 . These pro- 
jects involved no direct assault on England or the United States. They were directed exclusively to American territories of a third power, and threatened a change simply in an American country, which France might obtain by cession, or as indemnity for war.

It is no longer for us a question of the divine right of despotism to extend its sphere of supremacy to America, as it was in $1822-23$. It is a question now of commercial control, and exclusive commercial and military advantages. Covetous eyes are cast on outlying islands and continental coasts of Central and South America. A steamship line is preferred to an army; a canal to a fortification; a good harbor to a strong citadel. One far-sighted government, eager for the extension of its foreign trade and naval influence, has initiated negotiations for the transfer to it of a seemingly unimportant but really commanding tract of waste land. The weak government approached may be disposed to yield. The islands of the central, the Pacific, and the southern seas have become objects of special interest and examination to more than one of the naval and commercial powers of the Old World. At least two of the continental powers have been looking diligently for new colonial stations across or in the world of western waters. The unhappy and repeated dissensions and irregularities of 
the Central and South American states furnish too many occasions for European interference and claims of indemnity. Their resulting financial condition offers too strong temptation to relieve embarrassments by the expropriation of territorial rights and privileges. It is easy to find occasion for a naval war, if any European power desires a pretext for the seizure of a port or a territory. The recognized doctrine of a war indemnity stands in aid of the acquisitive purpose. To establish a colonial dependency in America by treaty, or as a result of war, - these alternatives, according to Señor Calvo, remain to the European nations without violating the principle of the Monroe Declaration.

Europe would be misled by the acceptance of that view, and still more deceived by accepting it as indicating the principles distinctly held on this subject by the United States during the last fifty years.

The original Declaration was limited, in words, by the circumstances of that epoch. The reasons upon which it was founded provided room for a further development and extension of the declaration. This government has from time to time indicated this development, and shown its desire to preserve always toward the ambitious commercial powers of Europe an attitude of candor and dignity, while 
defending its own rights and interests. There was no display of mere sentiment against monarchical institutions in America. On the contrary, our government recognized the imperial establishment of Iturbide in Mexico, and Dom Pedro in Brazil, because both were by choice of the people, and were home powers. Indeed, the Brazilian diplomatic agent told Mr. Adams that the Brazilian emperor was more republican than the people whom he ruled. On the other hand, we have always claimed that it was our material interests which demanded the maintenance of the American principle of noncolonization and non-acquisition by Europe on the western continents. While acknowledging existing colonial rights, Mr. Adams was of opinion that "we could not see with indifference any attempt . . . to transfer any portion of the ancient or present American possessions of Spain to any other European power." Mr. Rush was ready to unite with Mr. Canning in declaring that "we could not see any portion of them transferred to any other power with indifference." Mr. Jefferson advised President Monroe - facing a possible war for the principle - "to establish the American system of keeping out of our land all foreign powers; of never permitting those of Europe to intermeddle with the affairs of our nations;" and to oppose, "most especially, their transfer (of 
the Spanish-American possessions) to any power by conquest, cession, or acquisition in any other way."

Our own happy condition is not, unfortunately, that of all our neighbors of this hemisphere. It will not be theirs for many years to come. Their weakness has invited, their internal disorders have provoked, the acquisitive passions of several European governments. The persistent interference of the British in Nicaragua was one long vexation to that weak nation, to our government, and to our interests in Central America. Through it all, our government asserted the non-colonization principle. It was not settled, though earnestly desired, by the Anglo-Nicaraguan treaty of 1860, which has been itself the subject of arbitration. In 1848 , Yucatan, too weak to suppress by her own arms the general insurrection of her uncivilized Indians, appealed to England and to Spain for help. This being refused, she offered to the United States her sovereignty in exchange for the required assistance. Mexico claimed this sovereignty; and our government, although at war with her, refused the offer, but proposed to aid this detached state of the Mexican federation. President Polk, in his message of December, 1845 , after approving the Monroe Declaration, had said that it should be distinctly announced to 
the world as our settled policy, that "no future European colony or dominion shall, with our consent, be planted or established on any part of the American continent." On this

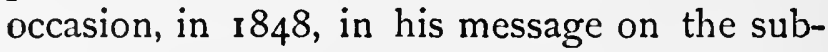
ject of Yucatan, he further declared that "we could not consent to a transfer of this dominion and sovereignty, either to Spain, Great Britain, or any other European power; ... it would be dangerous to our peace and security if it should become a colony of any European nation."

The attempt to plant an Austro-French empire in Mexico is so recent as to need little explanation. It was a conception of the French emperor, which he hoped to execute during our civil war, and by its success not only to obtain commercial advantages, but to discredit the republican system in America and break its prestige in Europe. It furnished an occasion to manifest again, and in a practical way, the adhesion of our government to the principles announced forty years previously. The representations of our government to both France and Austria were explicit, and, after the spring of 1865 , very resolute in their tone toward the imperial cabinet at Paris. In fact, the French-American relations became at one time very delicate; we had an army of observation on the Mexican frontier, and the sec- 
ond in rank of our army officers was ordered to the side of President Juarez in Mexico. A direct engagement was finally made by the French government to the American for the definitive withdrawal of the French troops in a limited time. The emperor promised for the future non-interference in Mexican affairs. That sad chapter of the history of European intervention in America presents one relief of color to an otherwise melancholy picture. It informed the governments of Europe how impossible it is for them to govern Americans, and how impracticable it is to extend their system to the New World. The attempt will not probably be repeated, except possibly for colonization in smaller territories or isolated possessions.

It may be very positively affirmed that the underlying motive of the non-colonization principle was and is the danger which European dominions in America offer to our material interests, both in peace and in war. It means a flanking position, a military and naval rendezvous in time of war, and an exclusive commercial position in time of peace. It invites the extension of purely European wars to American coasts and territories. Rights of commerce and navigation, often questioned, are referred to a distant government for settlement. Such questions, arising on one continent and re- 
ferred to another and distant continent for adjustment, always find the European tribunal of appeal to be dilatory, slowly informed, and hesitating in action. Justice, halting and reluctant, moves with slow steps across the seas.

It was largely, if not chiefly, to avoid these dangers that President Adams advised the participation of the United States in the Panama Congress. In his message of March, I 826, speaking of the advantages we derived from independent American states, he says: "The United States enjoy the right of commercial intercourse with every part of their possessions. To attempt the establishment of a colony in those possessions would be to usurp, to the exclusion of others, a commercial intercourse which was the common possession of all. It could not be done without encroaching upon existing rights of the United States." He further declares that among the subjects of consultation proposed at Panama was " the means of making effectual the assertion of that principle;" and he looked for mutual pledges, each nation for itself, "to permit no colonial lodgment, or establishment of European jurisdiction, upon its own soil." That policy had been urged also upon Mexico, in a separate correspondence conducted by Mr. Clay as Secretary of State. It was adopted by the four states represented at Panama. 
The continuity and uniformity of our national adherence to the Monroe Doctrine, irrespective of political parties, and the international publicity of our adherence to it, are fully shown by reference to the public messages of successive presidents addressed to the $\mathrm{Na}$ tional Congress.

President Polk in his first annual message (1845) alludes to the fact that in some of the countries of Europe it had been proposed to extend the doctrine of the "Balance of Power" to this continent, in order to check the rapidly growing preponderance of the United States. He adds this warning : . . " The United States, sincerely desirous of preserving relations of good understanding with all nations, cannot in silence permit any European interference on the North American continent; and should any such interference be attempted will be ready to resist it at any and all hazards."

Again, in his message of 1847 he says the Monroe principle that " no foreign power may with our consent be permitted to plant or establish any new colony or dominion in any part of the North American continent must be maintained."

In a special message ( 1847 ) relating to Yuca$\tan$ he reaffirms the Monroe principle, and declares that "we could not consent to a transfer of this dominion and sovereignty either to 
Spain, Great Britain, or any other European power."

President Buchanan, in his second annual message (1 858), while discussing the disordered condition of Mexico, says: "It is a duty which we owe to ourselves to protect the integrity of its territory against the hostile interference of any other power. Our geographical position, our direct interest in all that concerns Mexico, and our well-settled policy in regard to the North American continent render this an indispensable duty." Again, in I860, he admits the obligation of resisting, "even by force should this become necessary, any attempt by those [European] governments to deprive our neighboring republic of portions of her territory, - a duty from which we could not shrink without abandoning the traditional and established policy of the American people."

President Grant, in a special message to Congress (1870), confirmed and even extended the principle of 1823 . "The doctrine promulgated by President Monroe has been adhered to by all political parties; and I now deem it proper to assert the equally important principle that hereafter no territory on this continent shall be regarded as subject to transfer to a European power."

In a special message ( $187 \mathrm{I}$ ) he declared his opinion " that we should not permit any inde- 
pendent government within the limits of North America to pass from the condition of independence to one of ownership or protection under a European power."

In his annual message of 1895 President Cleveland advised Congress that in July of that year a communication had been sent by our government to London for the information of the British government in respect to its boundary dispute with Venezuela. The purport of that despatch he defined as follows: "The general conclusions therein reached and formulated are in substance that the traditional and established policy of this government is firmly opposed to a forcible increase by any European power of its territorial possessions on this continent; . . . that the United States is bound to protest against the enlargement of the area of British Guiana in derogation of the rights and against the will of Venezuela." And an explicit answer was desired to the question whether England will submit her claim to that territory to a free arbitration.

The British government denied the applicability of the Monroe Declaration to the Venezuelan boundary question. The President sent a special message to Congress in December 1895 , in which he maintained that it was so applicable. "If a European power by an extension of its boundary takes posses- 
sion of the territory of one of our neighboring republics against its will and in derogation of its rights, it is difficult to see why to that extent such European power does not thereby attempt to extend its system of government to that portion of this continent which is thus taken. This is the precise action which President Monroe declared to be dangerous to our peace and safety. It can make no difference whether the European system is extended by an advance of frontiers or otherwise."

The United States delegates to The Hague Conference of 1899 added a signatory declara. tion and notice to all the powers there represented as follows:-

"Nothing contained in this convention shall be so construed as to require the United States of America to depart from its traditional policy of not intruding upon, interfering with, or entangling itself in the political questions or policy or internal administration of any foreign state; nor shall anything contained in the said convention be construed to imply a relinquishment by the United States of America of its traditional attitude toward purely American questions."

Although the lucidity of this declaration might have been improved, its meaning was well understood by the international assembly; and it is well worthy of remembrance as 
the first formal and direct notice of our attitude on the Monroe Doctrine to an assembly of the civilized governments of the world. As such it was quoted and indorsed by President McKinley in his annual message of 1899.

President Roosevelt in his annual message of I9OI observed that the Peace Conference at The Hague " acquiesced in our statement of the Monroe Doctrine as compatible with the purposes and aims of the conference." $\mathrm{He}$ says also, "The Monroe Doctrine should be the cardinal feature of the foreign policy of all the nations of the two Americas, as it is of the United States. Just seventy-eight years have passed since President Monroe in his annual message announced that the American continents are henceforth not to be considered as subjects for future colonization by any European power." In other words, the Monroe Doctrine is a declaration that there must be no territorial aggrandizement by any nonAmerican power at the expense of any American power on American soil. It is in no wise intended as hostile to any nation in the Old World. Still less is it intended to give cover to any aggression by one New World power at the expense of any other. It is simply a step, and a long step, toward assuring the universal peace of the world by securing the possibility of permanent peace on this hemisphere. 
"During the past century other influences have established the permanence and independence of the smaller states of Europe. Through the Monroe Doctrine we hope to be able to safeguard like independence and secure like permanence for the lesser among the New World nations. . . . We do not ask under this doctrine for any exclusive commercial dealings with any other American state. We do not guarantee any state against punishment if it misconducts itself, provided that punishment does not take form of the acquisition of territory by any non-American power. ... Our people intend to abide by the Monroe Doctrine and to insist upon it as the one sure means of securing the peace of the western hemisphere."

It should be noted for remembrance in this connection that in 1902, before Great Britain and Germany sent their fleets to coerce Venezuela into a redress of grievances, both these great powers gave formal assurances to the United States government that there was no intention on their part to violate the principles of the Monroe Doctrine.

But, leaving the domain of authority and precedent, let us examine the Doctrine upon the grounds of reason.

What argument exists, on our part, to support an objection to Central or South Ameri- 
can colonization by Europe under claim of "prior discovery," which does not equally militate against colonization effected by war, or secured by a cession of territory? Our own territorial rights being untouched, in what way are we more injured by the former than by the latter? In either case it excludes or constrains our commercial interests as secured by existing treaties. In either case it creates for us a new and possibly dangerous neighbor, and new relations. If secured by one of the naval powers, it exposes us to a new military danger. If accomplished by a great power, it compels the increase of our own military or naval preparations to preserve our equality in the event of war. If near our great lines of commerce, it becomes a standing menace to our commercial relations. It touches every national interest. It is self-evident that we could not regard such an establishment, in whatever way of peace or war effected, "with indifference," as the diplomatists put it. It would, and it ought to, cause serious inquietude to our government. Need we recall again the Nicaraguan dispute, which brought us to the verge of war? Do we not remember the squadron despatched to the $\mathrm{An}$ tilles by the British government, when they believed France was seeking to acquire Cuba by cession, and Mr. Canning's protest against that cession? Yet that could affect England 
in no sense equal to the effect upon us of the acquisition by a great European power of Cuba, or of any other strong position, insular or continental, commanding either side of Central America, or the chief lines of our commercial routes along this or the southern continent.

In another respect any new European acquisition on this continent would touch very seriously our important interests. Delegated authority, exercised across distant seas, is the occasion of frequent misunderstandings and commercial embarrassments. The reparation or remedy is referred to a distant government, and is tediously obtained, if obtained at all. A supreme government in immediate contact obviates this danger of disturbance to commerce and to amicable relations. Canada and Cuba have repeatedly illustrated, and amply, the justice of this ground of objection to further colonial establishments in this hemisphere. It is not long since one of these questions in connection with Cuba cost us four millions in naval preparations to secure justice for wrongs there perpetrated. Either great or petty causes of irritation are continually arising with the colonial dominions on the north of us. Their semi-independent condition encourages a freedom of action sometimes in conflict with our rights and interests, but without the authority, 
however willingly disposed, to assure us relief or remedy by treaty. Our future relations with this dominion will cause - already cause anxiety to thoughtful American statesmanship, from which there now appears no certain issue, except in its independence. Our increasing settlements and interests on the Northern Pacific coast bring British Columbia still more forcibly within the scope of these considerations.

The European critics of the Monroe Doctrine say that it is not recognized as a part of the code of international law, and dces not therefore bind other nations, and is not entitled to observance by them. Was the doctrine of the "Balance of Power" a part of that code? Was it declared in that code that Russia should not seize Constantinople? or that France should not seize and appropriate to her own trade the great ports of China? Would Germany for that reason permit France or England to take permanent possession of the port of Rotterdam or of Antwerp? or acquire a strong military or naval position on the coast of Denmark? Would the European powers quietly permit the United States, because of the silence of the international code on the subject, to acquire Sicily, and establish a republican dependent government there? "Spheres of influence" are not recognized by interna- 
tional law, but they are respected by the common sense of nations; and this recognition promotes the peace of the world.

We must maintain the Doctrine, not merely the Declaration, of President Monroe's administration, in the light of later experience and of wider development of interests. The time is most favorable. Our foreign relations are universally amicable. Our domestic prosperity and contentment free the government from anxious interior cares. Our finances are well ordered and satisfactory. We can freely turn our eyes abroad, not for aggressive action, but for peaceful and secure development. We can tranquilly determine our policy upon the questions under review, and inquire whether we ought not to advance from the earlier Declaration, made by the President eighty years ago, when we had no commercial Pacific coast, to a position and to action more appropriate to our present condition and interests, and to the ambitions of other governments. For our own territory, or for our political system - defended by eighty millions of people devoted to it, and ready to spring to arms for its defence - we fear nothing. The sentiment of monarchy toward popular republics has radically changed. Liberty has advanced eastward with long strides, while despotism has receded to the borders of Asia. History, authority, reason, and 
existing conditions amply justify the formal declaration of the principle foreshadowed by Mr. Monroe's advisers. The United States could not witness with indifference the establishment on these American continents, or on any island of their borders, of any new European military or naval position, in whatever way acquired; nor of any new colony, under European jurisdiction; nor the transfer to any other European naval power of any existing American colonial dependency.

It is not necessary to disclose here all the reasons which urge us to the early and resolute adoption of this principle, and to the preparation of all needful means for its enforcement. If not now formulated and declared, it should be accepted by our statesmen, not as a topic for academical discussion or wild oratory, but as a basis for firm and decisive action, and in full view of its possible consequences. We have not failed to observe in the history of British-American relations a singular alternation of equitable and aggressive dispositions toward the United States - the latter, unfortunately, manifested in times of our trouble or weakness. Germany and France are strong rival commercial and aggressive powers. Both have sought outlying positions of future advantage for commercial and military purposes. $\mathrm{He}$ is greatly mistaken who supposes that the 
rejection of the imperial dynasty by France has changed in this respect the spirit of the French governing classes. The sentiment which still dominates there is love of glory, and glory in foreign acquisitions: witness her persistent campaigns in Africa. The French nation has no permanent alliances: witness the discordant clamor for friendship to-day with England, yesterday with Austria, now with Russia, then with Italy, or with the Sultan. Her friendships remain so long as they are tributary to her interests or to her glory. The simple fact of her adoption of republican institutions has in no way changed her policy of territorial and commercial extension and acquisition. While America ardently desires the continuance of the present amicable relations with all these countries, yet, reviewing the last fifty years, we realize the dangers of a changed policy arising from a change of monarchs or of ministries.

Our American Republic has never cast a covetous eye upon any part of European territory, or of the neighboring African continent, nor upon any island off their coasts. Its policy has never in the course of its history indicated any desire to interfere with the territorial distribution of Europe, or with its forms of government, or with the internal affairs of its various nations. On the contrary, we have repeatedly affirmed our policy of absolute non. 
interference and non-acquisition of European or African territory. Even the vast discoveries of Central Africa, made by Stanley under the American flag, did not tempt the Republic to swerve from her principle of non-acquisition of transatlantic domains. In return, America demands the like non-intervention by European powers in the affairs of the American continents, and the like non-acquisition of American territorial or insular possessions. This reciprocal policy will not only contribute to the mutual prosperity of nations, but tend strongly to the preservation of international peace, which is now the common aspiration of all Christian nations. 


(.)

(I)

(.)

. (1) 